\title{
FAUNA EDÁFICA EM FRAGMENTOS FLORESTAIS E EM ÁREAS REFLORESTADAS COM ESPÉCIES DA MATA ATLÂNTICA
}

\author{
FABIANE DUCATTI
}

Dissertação apresentada à Escola Superior de Agricultura "Luiz de Queiroz", Universidade de São Paulo, para obtenção do título de Mestre em Recursos Florestais, com opção em Manejo de Florestas de Produção.

PIRACICABA

Estado de São Paulo - Brasil

Outubro - 2002 


\title{
FAUNA EDÁFICA EM FRAGMENTOS FLORESTAIS E EM ÁREAS REFLORESTADAS COM ESPÉCIES DA MATA ATLÂNTICA
}

\author{
FABIANE DUCATTI \\ Engenheiro Florestal \\ Orientador: Prof. Dr. JOSÉ LEONARDO DE MORAES GONÇALVES
}

Dissertação apresentada à Escola Superior de
Agricultura "Luiz de Queiroz", Universidade de São
Paulo, para obtenção do título de Mestre em Recursos
Florestais, com opção em Manejo de Florestas de
Produção.

PIRACICABA

Estado de São Paulo - Brasil

Outubro - 2002 
Dados Internacionais de Catalogação na Publicação (CIP) DIVISÃO DE BIBLIOTECA E DOCUMENTAÇÃO - ESALQ/USP

\author{
Ducatti, Fabiane \\ Fauna edáfic a em fra gmentos floresta is e em á reas reflorestadas com \\ espéciesda Mata Atlântica / Fabiane Ducatti. - - Piracicaba, 2002. \\ 70 p. : il. \\ Dissertação (mestrado) - - Escola Superior de Agricultura Luiz de \\ Queiroz, 2002. \\ Bibliografia. \\ 1. Espécie florestal 2. Fa una edáfic a 3. Fragmento florestal 4. Mata \\ Atlântica 5. Reflorestamento I. Título
}

CDD 634.956

"Permitida a cópia total ou parcial deste documento, desde que citada a fonte - $\mathrm{O}$ autor" 
Aos meus pais Mauro e Tereza, aos meus irmãos Marcos e Francisco, à Dóris e Sandra, ao Vitor e Rodrigo: meus amores.

\section{DEDICO}




\section{AGRADECIMENTOS}

Ao Prof. Dr. José Leonardo de Moraes Gonçalves, pela orientação e incentivo durante todo o processo de realização deste trabalho $\mathrm{e}$, principalmente, pela amizade $\mathrm{e}$ compreensão.

À Faculdade de Ciências Agrárias de Botucatu (UNESP), pela concessão da área para o experimento e, especialmente, à Professora Vera Lex Engel pelas sugestões e suporte durante as amostragens

Ao Departamento de Entomologia, Fitopatologia e Zoologia Aplicada da ESALQ/USP, em especial ao professor Gilberto José de Moraes, pela liberação do uso dos extratores, e aos pesquisadores Jeferson Mineiro e Anibal Ramadan Oliveira, que me ensinaram noções básicas de morfologia e identificação acarina.

Ao Eng. Florestal Lauro Rodrigues Nogueira Junior, pela paciência, introdução ao projeto e à área experimental e pela grande ajuda durante as coletas. Ao Dr. Sebastião Pires, pela auxílio prestado e pela preocupação com o andamento do meu trabalho.

Aos funcionários do Laboratório de Ecologia Aplicada (LEA) pelo liberação de sala para armazenamento das amostras. À Maria Bermudez, do Laboratório de Dendrometria e Anatomia da Madeira, pelo empréstimo de equipamento para a identificação da fauna.

Ao Pesquisador Paulo César Teixeira, pelas correções feitas no texto e pelas sugestões e críticas passadas durante a qualificação.

Ao Ivo Rosa Filho (SAI) e José Amarildo da Fonseca (Viveiro), por toda ajuda sempre prontamente dispensada.

À amigas Marília Cantarelli (Bronzina) e Juliana Bouchardet (Juá), pelo companheirismo constante e sem restrições. Aos amigos Sedex (Alexandre Astorino) e André Dogini, pelo grande e decisivo auxílio durante as coletas. 


\section{SUMÁRIO}

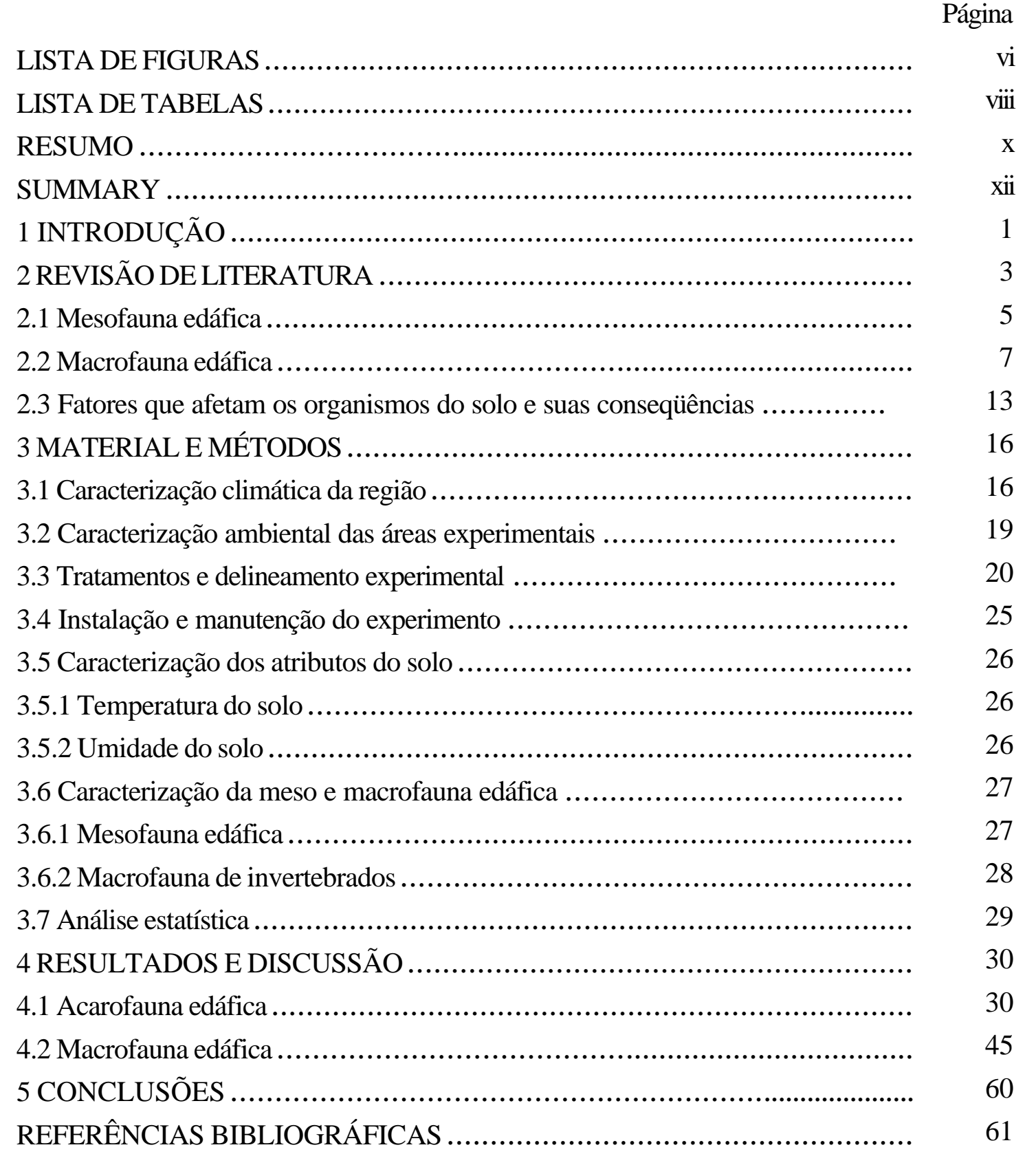




\section{LISTA DE FIGURAS}

1 Localização da região de Botucatu dentro do Estado de São

Página

Paulo

2 Precipitação pluviométrica e temperaturas médias de novembro de 1998 a abril de 2001 e médias históricas (média de 28 anos), na Fazenda Lageado

3 Balanço hídrico (THORNTHWAITE-MATHER - 1955) da Faz. Lageado, em Botucatu, com: a) dados médios de 1971 a 1988 e b) dados médios de 1999 e 2000

4 Vista geral do Fragmento Florestal do (a) NV, (b) PVA e (c) LVA ........ 22

5 Vista geral do NV em (a) julho de 1999 e (b) março de 2001 ............... 23

6 Vista geral do PVA em (a) julho de 1999 e (b) março de 2001 .............. 23

7 Vista geral do LVA em (a) julho de 1999 e (b) março de 2001 .............. 23

8 Caixa extratora de ácaros do solo .......................................... 28

9 Quantidade de amostras sem ácaros (média + erro-padrão) nos tratamentos Fragmento e Revegetação, nas diferentes épocas de amostragens, no: a)NV, b) PVA e c) LVA

10 Temperatura do solo (média \pm erro-padrão) a $5 \mathrm{~cm}$ de profundidade, medida às 14:00 hs, com 3 repetições, e umidade do solo (média \pm erro-padrão) $(0-15 \mathrm{~cm})$ com 3 repetições, nas diferentes épocas de amostragens no Revegetação e no Fragmento no: a) NV, b) PVA e c) LVA

11 Densidade total (média \pm erro-padrão) de ácaros em cada tratamento na média de todas as amostragens, e densidade média (média \pm erro-padrão) de cada solo 
12 Dendrogramas obtidos pela análise de Cluster para a densidade de ácaros na média de todas as amostragens, discriminando os tratamentos para todos os solos e utilizando-se a Distância Euclidiana e Ligação Simples

13 Temperatura (média \pm erro padrão) e umidade do solo (média \pm erro-padrão), média de todas amostragens, nos diferentes solos

14 Participação de cada subordem de ácaro na média de todas as amostragens, nos solos a) NV, b) PVA e c) LVA

15 Distribuição sazonal do total de ácaros, média de todos os solos

16 Temperatura do solo (média \pm erro-padrão) a $5 \mathrm{~cm}$ de profundidade e umidade do solo (média \pm erro-padrão) $(0-15 \mathrm{~cm})$ nas diferentes épocas de amostragens, no NV, PVA e LVA

17 Densidade total (média \pm erro-padrão) de macrofauna em cada tratamento, na média geral de todas as amostragens, e densidade média (média \pm erro-padrão) de cada solo

18 Dendrogramas obtidos pela análise de Cluster para a densidade de macrofauna na média de todas as amostragens, discriminando os tratamentos para todos os solos, e utilizando-se a Distância Euclidiana e Ligação Simples ..

19 Quantidade de amostras sem macroinvertebrados (média + erropadrão) nos tratamentos Revegetação e Fragmento, nas diferentes épocas de amostragem no: a) NV, b) PVA e c) LVA .......................

20 Participação de cada subordem de macrofauna edáfica na média de todas as amostragens, nos solos a) NV, b) PVA e c) LVA

21 Distribuição sazonal do total de macrofauna edáfica, média de todos os solos 


\section{LISTA DE TABELAS}

1 Grupo, família, nome científico, vulgar e indivíduos/parcela das

Página

espécies utilizadas nas associações de espécies nos tratamentos

2 Valores obtidos pelo teste de Friedman para a densidade de ácaros em cada época de amostragem

3 Densidades observadas (média \pm erro-padrão) para a ocorrência de subordens de ácaros no NV, nos diferentes tratamentos e épocas de amostragem

4 Densidades observadas (média \pm erro-padrão) para a ocorrência de subordens de ácaros no PVA, nos diferentes tratamentos e épocas de amostragem

5 Densidades observadas (média \pm erro-padrão) para a ocorrência de subordens de ácaros no LVA, nos diferentes tratamentos e épocas de amostragem

6 Atributos físicos e químicos dos solos nos tratamentos

Revegetação e Fragmento no NV, PVA e LVA................................

7 Estabelecimento (45 dias pós-semeadura) e crescimento das plantas (dois anos pós-semeadura) no Sem.Direta no NV, PVA e LVA

8 Valores obtidos pelo teste de Friedman para a densidade de macrofauna em cada época de amostragem

9 Densidades observadas (média \pm erro-padrão) para a ocorrência de grupos de macrofauna no NV, nos diferentes tratamentos e épocas de amostragem

10 Densidades observadas (média \pm erro-padrão) para a ocorrência de grupos de macrofauna no PVA, nos diferentes tratamentos e épocas de amostragem 
11 Densidades observadas (média \pm erro-padrão) para a ocorrência de grupos de macrofauna no LVA, nos diferentes tratamentos e

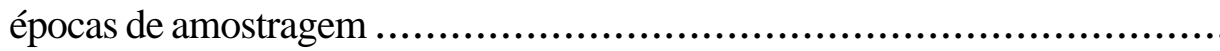




\title{
FAUNA EDÁFICA EM FRAGMENTOS FLORESTAIS E EM ÁREAS REFLORESTADAS COM ESPÉCIES DA MATA ATLÂNTICA
}

\author{
Autora: FABIANE DUCATTI \\ Orientador: Prof. Dr. JOSÉ LEONARDO DE MORAES GONÇALVES
}

\section{RESUMO}

$\mathrm{O}$ estudo teve por objetivos caracterizar quantitativa e qualitativamente as principais classes taxonômicas da meso e macrofauna edáfica presentes em fragmentos de Floresta Estacional Semi Decidual (domínio de Mata Atlântica) e em diferentes modelos de reflorestamentos com espécies da Mata Atlântica. As áreas utilizadas pertencem à Faculdade de Ciências Agronômicas, UNESP, em Botucatu/SP. Os experimentos foram instalados em três solos usados intensivamente com exploração agrícola e pastagem: Nitossolo Vermelho (NV) textura argilosa, Argissolo VermelhoAmarelo (PVA) Distrófico textura média e Latossolo Vermelho-Amarelo (LVA) Distrófico textura areia franca. O delineamento usado foi o de blocos casualizados, com três blocos e seis tratamentos. Um tratamento foi demarcado sobre floresta natural (Fragmento) e outros cinco tratamentos instalados sobre áreas revegetadas: testemunha, semeadura direta, sistema Taungya modificado, consorciação de espécies nativas de rápido crescimento com espécies comerciais para madeira e mistura de espécies nativas em modelos de plantio-restauração. As amostragens semestrais foram realizadas durante dois anos. A mesofauna foi extraída pelo método de Berleusse-Tüllgren modificado e a macrofauna pelo método dos monolitos. Os dados de densidade dos organismos foram 
analisados pelo teste de médias não-paramétrico de Friedman e pela análise multivariada de Agrupamento (Cluster Analysis). Nos tratamentos com cobertura vegetal mais densa e solo menos perturbado (Fragmento, Testemunha e Sem.Direta), foram verificadas as maiores densidades de organismos da meso e macrofauna edáfica. Houve uma relação direta entre a densidade de organismos e os atributos físicos e químicos dos solos; no solo mais úmido, de menor temperatura média, mais permeável, mais fértil e mais rico em matéria orgânica, $\mathrm{NV}$, foram encontradas as maiores densidades de organismos da meso e macrofauna edáfica. Dentre as subordens de mesofauna, os oribatídeos foram encontrados com maior densidade em todos os solos e, os Astigmatas e Prostigmatas, em menores quantidades. Na macrofauna, o grupo das Oligochaetas foi o mais encontrado no NV, seguido do Formicidae; os grupos Isoptera, Coleoptera e Formicidae foram os mais encontrados no PVA e LVA. Independente do tipo de solo, a densidade de organismos da mesofauna edáfica foi maior no verão que no inverno. Para a macrofauna, as variações estacionais da densidade de organismos ocorreram somente no LVA, com $54 \%$ no verão, e foram influenciadas pelas condições físicas e químicas do solo. 


\title{
SOIL FAUNA IN FORESTAL FRAGMENTS AND IN REFORESTED LANDS WITH SPECIES FROM THE ATLANTIC FOREST
}

\author{
Author: FABIANE DUCATTI \\ Adviser: Prof. Dr. JOSÉ LEONARDO DE MORAES GONÇALVES
}

\section{SUMMARY}

The purposes of this study was to point out quantitaty and qualitivetely the main taxononomics classes of the meso and macrofauna soil, on fragments of Seasonal Semideciuos Tropical Forest (Atlantic Forest) and prototypes of Atlantic Fores reforestation programs, using native species. The reserched areas belong to Faculdade de Ciências Agronômicas, UNESP, located in Botucatu, SP, Brazil. The experiments took place in three different soil previously used heavily for agriculture and cattle: Alfisol clayey texture, Ultisol medium texture and Oxisol sandy texture. The experiment was marked by random blocks, with three replications and six treatments. One treatment was done over the natural forest followed by five other done over reforested lands: test, direct seeding, modified Taungya system, mix from native fast growing species with species used commercially and another mix from native species in restoration-planting model. The semestral samples were collectes for a period of two years. The BerleusseTüllgren modified method were used to extrat the mesofauna, and the Monolitos method to extract the macrofauna. The density data of the organisms were analyzed using the Friedman's non-parametric medias test as well as multivariate Cluster Analysis. On denser vegetation and less stressed soil (Fragment, Test and Direct Seeding), our 
treatment resulted on a higher density of organisms of meso and macrofauna. A relation between the density of organisms and the physical and quimical caracteristic of the soil was clearly defined: on a humid soil, low average temperature, permeable, higher degree of fertility and richer on organic matter, NV, it was detect the higher density of soil meso and macrofauna. Within the suborder of the mesofauna, the Oribatida could be found on higher density on all different types of soils and a smaller number in regards to the Astigmatas and Prostigmatas under the same circunstances. On the macrofauna, the Oligochaetas was found on higher density on the Alfisol, followed by Formicidae; the Isoptera, Coleoptera and Formicidae showes a bigger presence on the Ultisol and Oxisol. Independent of soil type, the density of soil mesofauna organisms was higher on the summer than the winter. For macrofauna, the density variation of organisms, based on the different climate seasons, ocurred only on the Oxisol, with a 54\% in the summer, and had suffere the physical and quimical influence of the soil. 


\section{INTRODUÇÃO}

Originalmente, a Mata Atlântica possuía cerca de 130 milhões de ha, estava distribuída em 17 estados brasileiros e ocupava cerca de 15\% do território nacional, mas hoje está reduzida a menos de $8 \%$ ou cerca de 100 mil $\mathrm{Km}^{2}$. A Região Sudeste possui apenas 7,16\% de área florestal remanescente. Em São Paulo, as florestas nativas cobriam 81,8\% da área total do estado, mas perfaziam apenas 7,64\% em 1995 (Bacha, 1993; Macedo, 1997; Buschbacher, 2000; SOS Mata Atlântica, 2001).

Apesar de distintas, as causas da degradação podem ser explicadas basicamente pelo manejo do solo (Luchesi et al., 1992) e incluem a erosão e compactação do solo, e o aumento da perda de nutrientes por lixiviação e volatilização (Gonçalves et al., 2000). Uma das conseqüências da alteração do ambiente é a mudança nas características biológicas do solo, que são afetadas de modo distinto, em curto e em longo prazo. A retirada da cobertura vegetal, o manejo agrícola e a formação de pastagens afetam a fauna e os microrganismos tanto devido às modificações nas propriedades do solo, como pela ação direta destas práticas (Guerra et al., 1982; Almeida, 1985; Teixeira \& Schubart, 1988; Lopes Assad, 1997). Essas alterações exercem influência não só no número, como também nos tipos de organismos do solo (Brady, 1983).

Em casos de amplas modificações dos ecossistemas, são necessários estudos apropriados que utilizem bioindicadores e monitoramento biológico, que referem-se à avaliações da qualidade do ambiente baseadas em medidas de seleção biológica, podendo constituir bom indicador da degradação e da reabilitação do ambiente Sautter \& Santos, 1991; Curry \& Good, 1992). Entre os diferentes grupos da fauna do solo, há três categorias possíveis de indicadores que variam desde (i) nível individual e populacional, (ii) características da comunidade (diversidade e associações tróficas) e 
(iii) processos biológicos (bioacumulação e decomposição de resíduos). Portanto, a medida da abundância, diversidade e atividade de certas espécies ou reunião de organismos pode fornecer proveitosos indicadores da qualidade do solo (Linden et al., 1994).

Assim, este estudo teve por objetivos caracterizar quantitativa e qualitativamente as principais classes taxonômicas da meso e macrofauna edáfica presentes em fragmentos florestais de Floresta Estacional Semi Decidual (domínio de Mata Atlântica) e em diferentes modelos de reflorestamentos com espécies da Mata Atlântica, instalados em três solos (NV, PVA e LVA) usados intensivamente com exploração agrícola e pastagem.

Foram testadas as seguintes hipóteses:

- Quanto maior a cobertura e produção vegetal, maior a densidade de organismos da meso e macrofauna edáfica;

- A população da fauna edáfica é maior nos solos mais permeáveis, férteis e ricos em matéria orgânica; e

- A população da fauna edáfica é influenciada pelas variações sazonais, sendo maior nas estações mais úmidas e quentes do ano. 


\section{REVISÃO DE LITERATURA}

Todos os ecossistemas florestais acumulam uma camada de resíduos orgânicos sobre o solo, resultante da queda de folhas, galhos, casca, árvores inteiras tombadas, excrementos ou animais mortos (Sautter \& Trevisan, 1994; Poggiani et al., 1996). Após estes materiais entrarem na cadeia de detritos, eles começam a se decompor, e o desaparecimento da serapilheira (Manta florestal) por meio do processo de decomposição e liberação de elementos inorgânicos (mineralização) é essencial para a manutenção da produtividade dos ecossistemas florestais (Poggiani et al., 1996).

De modo geral, a decomposição dos resíduos orgânicos e a ciclagem biológica de nutrientes são estudadas como conseqüência da atividade de microrganismos, mas um conjunto diverso de animais influencia de maneira decisiva o funcionamento da flora decompositora, como resultado direto e indireto de sua atividade de alimentação (Poggiani et al., 1996; Lopes Assad, 1997). Portanto, um número muito grande de organismos interage com o solo: as plantas, a microbiota (bactérias, actinomicetos, fungos, protozoários, algas) e a fauna do solo (nematóides; moluscos; anelídeos: minhocas, enquitreídeos; artrópodes: crustáceos, miriápodes, ácaros, insetos como colêmbolas, besouros, formigas, cupins etc) (Miklós, 1998).

A principal função dos microrganismos é decompor o material orgânico, liberando as substâncias químicas em formas assimiláveis pelas plantas, como nutrientes, vitaminas, enzimas, reguladores de crescimento, aminoácidos e hormônios, o que pode influenciar favorável ou desfavoravelmente o desenvolvimento das plantas e dos organismos restantes do solo (Almeida, 1985). Portanto, a atividade que desempenham no solo está intimamente relacionada com a própria formação do solo, sua fertilidade, estrutura e condições da sanidade (Tsai et al., 1992). 
Inúmeros são os grupos taxonômicos que compõem a usualmente denominada fauna edáfica de invertebrados, e algumas classificações, como a apoiada no tamanho e na mobilidade dos organismos, é bastante difundida, atualmente, entre os pedobiólogos tropicais. Esta divisão classifica os animais em: microfauna $(<0,2 \mathrm{~mm})$, mesofauna $(0,2-$ 2,0 mm) e macrofauna $(>2,0 \mathrm{~mm})$. A primeira divisão engloba animais ligeiramente mais móveis que a microflora, como nematóides. A mesofauna é constituída por espécies que se movimentam nos poros do solo, nas fissuras e na interface entre a liteira e o solo e, como macrofauna, são classificados os animais de grande mobilidade que exercem importante papel no transporte de materiais (Poggiani et al., 1996; Lopes Assad, 1997).

Conforme o tipo, hábito e tamanho do corpo, existe um método mais adequado para estimar o tamanho das populações desses animais no solo. Em solos florestais, a mesofauna e a macrofauna, pela sua importância, são os mais freqüentemente estudados. A macrofauna normalmente é estimada por catação manual nas amostras coletadas no campo (Poggiani et al., 1996). A mesofauna, incluindo os ácaros de solo, geralmente é estimada com o emprego de funis tipo Berlese-Tullgreen (Flechtmannn, 1975; Poggiani et al., 1996).

Em áreas não degradadas, o horizonte superficial dos solos ou horizonte A caracteriza-se por ser friável e rico em matéria orgânica, em relação aos horizontes mais profundos. Neste horizonte, ocorre a maior atividade de micro e macrorganismos e de raízes secundárias das espécies vegetais (Brady, 1983; Griffith et al., 1994). Da mesma foram, Soares \& Costa (1991), constataram que as maiores densidades populacionais se concentram nos primeiros $10 \mathrm{~cm}$, onde verificaram a ocorrência de 97,7\% do total de fauna do solo em área com Eucalyptus spp. Ainda assim, não é fácil prever o número, o tipo e a atividade dos organismos que podem ser encontrados num determinado solo, pois eles dependem, além do clima e da vegetação, de fatores do solo como umidade, temperatura, aeração, acidez, suprimento de nutrientes e de energia, e grau de perturbação (Brady, 1983; Curry \& Good, 1992; Fisher \& Binkley, 2000).

A maioria dos componentes da meso e macrofauna melhoram o solo, especialmente no que diz respeito à mobilização de nutrientes; fragmentam os resíduos 
orgânicos, misturando-os com o solo mineral e contribuindo com a incorporação da matéria orgânica, e ainda regulam as populações de fungos e bactérias pela predação ou dispersão de propágulos desses organismos (Brady, 1983; Primavesi, 1990; Poggiani et al., 1996; Lopes Assad, 1997) . As galerias construídas e a excreção de "pellets" fecais por organismos do solo modificam o espaço poroso, desempenhando importante papel na aeração e na permeabilidade do solo, pois facilitam a circulação do ar e a infiltração de água no solo. Os bioporos também facilitam a penetração de raízes, interferindo na sua resistência mecânica e no padrão de penetração (Brady, 1983; Primavesi, 1990; Poggiani et al., 1996; Lopes Assad, 1997; Fisher \& Binkley, 2000).

Os vegetais e a fauna do solo também participam da agregação-desagregação da matéria mineral por meio de sua relação com os fenômenos hidrogeoquímicos, promovem transformações das alteritas de rocha em solo, além de forte estruturação do solo (descompactação) e de aumento da porosidade e da transferência de argila para a superfície do solo (remonte vertical) (Miklós, 1998). Portanto, a fauna do solo exerce uma atividade tanto física quanto química no solo (Brady, 1983), mantendo os sistemas que servem de suporte para as plantas superiores (Trinca, 1999).

\subsection{Mesofauna edáfica}

A maioria dos estudos sobre a mesofauna tem sido dirigidos à análise da influência das práticas agrícolas sobre as principais unidades taxonômicas como um todo, mais particularmente, sobre os grupos numericamente mais representativos, como os ácaros e colêmbolos (Primavesi, 1990; Bzuneck \& Santos, 1991; Lopes Assad, 1997), que podem ser usados como bioindicadores das condições ambientais.

Os ácaros (sub-classe Acari) pertencem à classe Arachnida e podem representar grande parte do total de mesofauna presente no solo, chegando a $78 \%$ na floresta e $84,7 \%$ na pastagem (Teixeira \& Schubart, 1988). Eles têm como principais características o reduzido porte e a ausência de segmentação (Flechtmann, 1983). De modo geral, o corpo dos ácaros apresenta forma muito variada e diferentemente dividida de um grupo ao outro. 
Esta marcante diversidade morfológica dos ácaros é acompanhada de grande variedade comportamental. De maneira geral, os ácaros podem ser agrupados em formas de vida livre e formas parasitas (Lopes Assad, 1997; Paschoal et al., 1996).

Quatro subordens de ácaros ocorrem freqüentemente nos solos: Prostigmata, Mesostigmata, Astigmata (Coleman \& Crossley, 1996) e principalmente os Oribatidas (ordem Cryptostigmata) (Paschoal et al., 1996; Oliveira, 1999), que constituem um dos mais numerosos grupos de artrópodos do solo, tanto em número de espécies quanto em número de indivíduos (Flechtmann, 1975).

A maioria dos Cryptostigmata ou Oribatida são dotados de escudos duros e protetores que envolvem todo o corpo. Seu tamanho varia de 0,2 a 1,3 mm, e apresentam uma reprodução relativamente lenta, com uma ou duas gerações por ano (Flechtmann, 1975; Coleman \& Crossley, 1996; Paschoal et al., 1996). De modo geral, o nível trófico dos oribatídeos é o de decompositores e quanto à nutrição, a maioria é microfitófaga, nutrindo-se de fungos ou algas. Basicamente, os oribatídeos ingerem alimento sólido (Paschoal et al., 1996), mas frente a diversidade desses ácaros, existem espécies que se alimentam de praticamente todos os recursos produzidos no solo (Oliveira, 1999). Normalmente, são encontrados nas camadas superficiais do solo (Flechtmann, 1975), com maior diversidade em horizontes orgânicos mais estruturados, com mais húmus (Krantz, 1978).

Os ácaros da Ordem Mesostigmata (ou Gamasida) caracterizam-se por apresentar tamanho médio $(0,2-2 \mathrm{~mm})$ e cutícula muito esclerotizada. São encontrados em todo o mundo, em associação com o solo, a matéria orgânica, as plantas e os animais (Paschoal et al., 1996), ocorrendo, a maior percentagem, numa profundidade de quatro a seis centímetros (Krantz, 1978). Alguns mesostigmatas podem ser importantes predadores de um ou mais estágios de seu inseto transportador e de outros microartrópodos; outros se alimentam de enquitreídeos e de nematóides no substrato de seu hospedeiro (Krantz, 1978; Lopes Assad, 1997; Paschoal et al., 1996) e algumas poucas espécies são fungívoras (Coleman \& Crossley, 1996).

Os ácaros da subordem Astigmata ou Acaridida são, em sua maioria, de movimentos lentos, apresentando cutícula elástica, transparente e que pode ter algumas 
regiões esclerosadas; variando de 0,2 a 1,8 mm de comprimento (Flechtmann, 1975; Paschoal et al., 1996). São cosmopolitas (Flechtmann, 1975) e podem ser encontrados na matéria orgânica superficial do solo, em ninhos de aves e roedores e em alimentos armazenados (Paschoal et al., 1992). Podem ter aumento significativo de sua população em consequiência da atividade humana, como a aplicação de inseticidas, que causa o declínio de predadores, e a fertilização nitrogenada, que aumenta a população de microorganismos, que são potenciais recursos alimentares para astigmatas micófagos e saprófagos (Krantz, 1978).

Os prostigmatas (subordem Prostigmata) são ácaros em geral pouco esclerosados quando comparados aos mesostigmatas. A falta de caracteres diferenciais que possam ser aplicados aos prostigmatas como um todo freqüentemente obriga a identificação da subordem por exclusão (Flechtmann, 1975). O padrão de alimentação destes ácaros é completamente heterogêneo, com espécies com múltiplos níveis tróficos (fungívoros, predadores, parasitas), que podem ingerir partículas sólidas e outras somente líquidos (Krantz, 1978; Coleman \& Crossley, 1996). As espécies fungívoras são oportunistas e estão aptas a reproduzir rapidamente após distúrbios ou mudanças súbitas no ambiente (Coleman \& Crossley, 1996).

\subsection{Macrofauna edáfica}

Os macroinvertebrados desenvolvem ações no solo que, por suas especificidades, conferem-lhes papel de destaque. Essas especificidades estão relacionadas principalmente com o volume de material que pode ser modificado, em suas características genéticas, pelos grupos de animais envolvidos (Lopes Assad, 1997). De acordo com Wolters \& Ekschmitt (1997), os macroinvertebrados podem contribuir com $33 \%$ da decomposição da liteira.

Um dos mais importantes grupos de animais do solo é formado por vermes que apresentam o corpo cilíndrico, composto por segmentos em forma de anel, sendo por isso chamados de anelídeos, formando o filo Annelida (Lopes Assad, 1997). A classe mais importante é a Oligochaeta, constituída por animais escavadores, sem cabeça 
diferenciada, e respiração tegumentar (Paschoal et al., 1992). Dentro desta classes, as minhocas comuns possuem corpo geralmente pigmentado e seu acasalamento se dá na superfície do solo no período noturno, quando esses animais são mais ativos (Lopes Assad, 1997).

Juntamente com a microflora, a minhoca monopoliza a atividade metabólica no solo (Curry \& Good, 1992). Sua nutrição é baseada principalmente em restos vegetais em decomposição provenientes da liteira, de troncos mortos, e de fezes de animais, misturados com quantidade variáveis de terra, mas nunca ingerem material vegetal vivo, a menos que o solo não tenha matéria orgânica suficiente (Paschoal et al., 1992; Lopes Assad, 1997). Materiais orgânicos com altos conteúdos de $\mathrm{N}$ e açúcares são mais palatáveis e aceitos do que materiais orgânicos pobres em nutrientes e ricos em polifenóis (Poggiani et al., 1996).

Comparado ao solo, os resíduos expelidos pelas minhocas (coprólitos) contêm maior quantidade de matéria orgânica, de nitrogênio total e sob a forma de nitratos, de cálcio e de magnésio trocáveis, de fósforo e de potássio assimiláveis e de porcentagem de saturação de base, assim como maior capacidade de troca de cátions (Brady, 1983). Estas dejeções estimulam o desenvolvimento das plantas e melhoram a disponibilidade de nutrientes, além de ter efeito positivo sobre a estrutura do solo (Trinca, 1999). Em solos tropicais, as minhocas podem depositar 600 ou mais toneladas dessas dejeções por hectare ano $^{-1}$ (Paschoal et al., 1992) e por isso, a grande população de minhocas é geralmente associada com a formação de húmus (Fisher \& Binkley, 2000).

As minhocas influenciam a fertilidade e a produtividade do solo em vários outros aspectos: os condutos deixados na terra servem para aumentar a capacidade de retenção de água (capilar e higroscópica), a aeração e a drenagem, facilitando a penetração das raízes e evitando a erosão (Paschoal et al., 1992). Além disso, as minhocas fazem transporte de quantidade considerável do solo subjacente para a superfície. Misturam também o solo e favorecem sua granulação, ao transportarem pelos orifícios, matéria orgânica não decomposta, tais como folhas e gramíneas que utilizam como alimento (Brady, 1983).

Por causa do frágil corpo e limitada mobilidade, as minhocas são susceptíveis a vários fatores bióticos e bióticos, que afetam sua condição de vida e sua atividade no 
solo, como o suprimento de alimento (energia e nutrientes) de alta qualidade, com altas densidades populacionais sendo encontradas somente em solos onde há fácil decomposição de folhas e raízes da liteira e/ou disponibilidade de fertilizantes orgânicos. No solo compactado, há aumento da percentagem de microporos, acompanhado pela formação de zonas anaeróbicas, o que reduz a população de minhocas. Em solos muito compactados, a diminuição de minhocas pode chegar a 50\% (Makeschin, 1997). A diminuição da temperatura do solo causa redução da atividade metabólica das minhocas, bem como alterações na quantidade e distribuição no perfil (Brady, 1983; Lopes Assad, 1997).

A população de artrópodes do solo, animais importantes na mistura do solo e na decomposição de organismos (Fisher \& Binkley, 2000), destaca-se pela grande diversidade, visto que esse grupo engloba número elevado de espécies que são, de modo geral, abundantes, principalmente em ambientes maturais ou pouco perturbados pela ação humana, como florestas plantadas e pastagens naturais (Lopes Assad, 1997).

A classe Diplopoda é constituída por animais conhecidos por piolhos-de-cobra, gangolôs ou embuás, que apresentam corpo cilíndrico, abdome com numerosas divisões, cada uma com dois pares de pernas curtas ventrais (Paschoal et al., 1992). Os diplópodas são os maiores consumidores de fragmentos orgânicos em florestas temperada e tropical onde alimentam-se predominantemente de material vegetal morto. Possuem um exosqueleto calcáreo e, por causa de sua alta densidade, podem ser uma significante fonte de cálcio (chegando a processar de 15-25\% do cálcio da superfície do solo), sendo, portanto, importantes na ciclagem de cálcio (Coleman \& Crossley, 1996). São animais noturnos, ficando escondidos à luz do dia. Somente abandonam seus esconderijos em período noturno quando os dias são chuvosos. Nos períodos secos, vivem em estado de dormência, e à noite costumam empreender migrações e vão se expandindo. Assim, disseminam-se por seus próprios movimentos ou pelo homem, que os transporta com material vegetal e solos (Wolters \& Ekschmitt, 1997; Paschoal et al. , 1996).

Pertencem à classe Chilopoda, animais comumente conhecidos como lacraias ou centopéias, que apresentam cabeça com antenas longas e corpo achatado dorsoventralmente com um par de forcículas inoculadoras de veneno no primeiro segmento 
(Paschoal et al., 1992). São carnívoros, quase exclusivamente predadores, embora ocasionalmente possam se alimentar de material vegetal em decomposição. Muitos são restritos a habitats escondidos, como sob pedras e sob cascas de árvores (ritidomas), nos musgos e no solo (Paschoal et al., 1992; Poggiani et al., 1996). Como os diplópodas, os centípedes (Chilopoda) perdem água diretamente da cutícula em baixa umidade relativa (Wolters \& Ekschmitt, 1997) e evitam o ressecamento procurando ambientes úmidos, ajustando a atividade diurna para períodos úmidos (Coleman \& Crossley, 1996).

Os insetos (classe Insecta) são artrópodes antenados que aparecem no solo em grande quantidade, tanto em termos de biomassa quanto em termos de número de indivíduos e de espécies (Lopes Assad, 1997) e constituem um elemento vital na complexa cadeia de relações entre a vida vegetal e a vida animal (Berti Filho, 1995).

Nos solos, os insetos mais importantes são as formigas (ordem Hymenoptera, família Formicidae), os térmitas (ordem Isoptera), os coleópteros (ordem Coleoptera), e os colêmbolos (ordem Colembola), além dos dípteros (ordem Diptera) (Coleman \& Crossley, 1996; Lopes Assad, 1997). Também encontra-se insetos das ordens Dermaptera (tesourinha) e Orthoptera (paquinha, grilo).

Os insetos da ordem Hymenoptera são sociais e os mais evoluídos da Classe Insecta (Gallo et al., 1978), apresentam sempre uma divisão do trabalho (Zucchi et al., 1992; Lopes Assad, 1997) e contém, de acordo com Berti Filho ${ }^{1}$, dois grupos de insetos do solo de grande importância: formigas e vespas de solo.

Em geral, a maioria das formigas coletadas na serapilheira de florestas tropicais é, pelo menos parcialmente, carnívora (Fisher \& Binkley, 2000). Algumas formigas constróem ninhos em vários tipos de cavidades de plantas, outras escavam galerias em troncos de árvores (formigas arborícolas), mas a maioria constrói seus ninhos no solo, sendo responsáveis pelo transporte de grande quantidade de subsolo para a superfície, com grande influência no equilíbrio pedológico (Poggiani et al., 1996; Lopes Assad, 1997; Fisher \& Binkley, 2000).

${ }^{1}$ Berti filho, E. Comunicação pessoal, 2002. 
Junto às formigas, os térmitas, comumente conhecidos como cupins e pertencentes à ordem Isoptera, constituem os dois grandes grupos de insetos sociais do solo (Lopes Assad, 1997). Vivem em colônias, num sistema de castas sociais bem desenvolvido (Zucchi et al., 1992). Alimentam-se de grande variedade de produtos de origem vegetal, como madeira e papel, e de produtos de origem animal, como o couro e a lã. As espécies xilófagas têm uma dieta à base de celulose (madeira morta, gramíneas e outras fontes difusas de celulose), que é digerida por microorganismos simbiontes existentes no intestino posterior (Berti Filho, 1993).

Os cupins apresentam-se distribuídos principalmente nos trópicos. Considera-se que exerçam nessas regiões o papel das minhocas na região temperada, como um dos principais agentes na fragmentação de material orgânico e sua mistura com o solo mineral (Poggiani et al., 1996). As minhocas e as formigas são os outros dois grupos de organismos considerados mais importantes na movimentação de solo (Coleman \& Crossley, 1996). Os térmitas colaboram com a ciclagem de nutrientes e contribuem para a aeração e a drenagem do solos (Berti Filho, 1995), mas Lopes Assad (1997) descreve que a função principal dos cupins na ciclagem de nutrientes deve-se à sua mortalidade.

Coleoptera é a maior ordem de insetos, possuindo extensas variações na forma, tamanho, função e distribuição. É encontrada em todo o mundo e em todos os habitats, exceto nos oceanos (Coleman \& Crossley, 1996). Grande número de famílias de besouros está entre os organismos que decompõem material orgânico, reciclando nutrientes, ou que controlam populações de decompositores por meio da predação. Assim, a importância destes insetos estaria no controle do processo de decomposição, via predação, da fauna detritívora propriamente dita (Penny et al., 1978). Porém, a enorme diversidade de espécies, famílias e estilos de vida torna qualquer generalização sobre o grupo impossível (Poggiani et al., 1996).

Moscas, pernilongos e mutucas pertencem à Ordem Diptera, quarta maior ordem de insetos, que apresenta grande diversidade, sendo encontrada em quase todos os locais (Berti Filho) ${ }^{1}$. Muitas espécies são hematófagas, outras transmissoras de doenças, algumas são formadoras de galhas ou minadoras de folhas, polinizadores ou decompositoras de matéria orgânica. Poucas espécies, como a mosca-da-madeira, são 
pragas florestais e muitas, como as da família Tachinidae, são parasitas de lagartas de lepidópteros, larvas de coleópteros etc (Berti Filho) ${ }^{1}$. As larvas que se desenvolvem em meio terrestre vivem às custas de matéria orgânica em decomposição, carcaças de animais mortos e excrementos (Gallo et al., 1978).

Insetos da ordem Dermaptera são conhecidos por tesourinhas devido a presença de duas pinças na extremidade do abdome (Gallo et al., 1978). De hábitos noturnos, vivem sob detritos e pedras no solo, casca do tronco e em galerias no solo ou em matéria orgânica. São onívoros e se alimentam tanto de matéria orgânica, vegetal ou animal, viva ou em decomposição e algumas espécies são predadoras de ovos, ninfas, larvas e pupas de insetos (Berti Filho) ${ }^{1}$.

Os ortópteros são terrestres, vivendo em árvores, arbustos, mudas novas e outros tipos de vegetação. Alguns, como as paquinhas e os grilos, escavam o solo, fazendo galerias superficiais. São insetos fitófagos que, eventualmente, podem predar outros insetos ou mesmo indivíduos da mesma espécie, principalmente quando o alimento é escasso (Berti Filho) ${ }^{1}$.

A classe Arachnida é composta por animais em geral terrestres, que possuem quelíceras com terminação em ponta para inoculação de peçonha e glândulas ou fiandeiras, que segregam seda para a confecção de teias (Lopes Assad, 1997). Aranhas são predadores comuns, que empregam inúmeras técnicas para capturar grande variedade de presas. A maioria dos artrópodos da serapilheira podem ser presas de aranhas em alguma época de sua vidas, e a atividade de predação das aranhas tem um efeito regulador potencialmente importante na comunidade (Poggiani et al., 1996), sendo os mais notáveis predadores de habitantes dos solo em agroecossistemas (Coleman \& Crossley, 1996; Ekschmitt et al. 1997).

Moluscos da classe Gastropoda são os mais importantes sob aspecto agronômico e de saúde pública, por encerrar os caracóis, os caramujos e as lesmas. Os gastrópodas estão presentes em quase toda parte, mas geralmente em maior abundância e diversidade em florestas com solos férteis (Paschoal et al., 1996). A competição entre gastrópodes, chilópodas e diplópodas pode ser temporariamente importante, após 
eventos catastróficos como o corte ou derrubada de florestas, que causa o esgotamento a curto prazo dos recursos essenciais (Wolters \& Ekschmitt, 1997).

\subsection{Fatores que afetam os organismos do solo e suas conseqüências}

Qualquer prática agrícola (aração, adubação, calagem, incorporação de matéria orgânica, irrigação, aplicação de agrotóxicos etc) pode afetar os nichos disponíveis por meio da intervenção nas características físico-químicas ou biológicas do ecossistema (Cardoso, 1992). Dependendo do tipo de impacto, as reações dos diferentes grupos de organismos podem ser negativas, positivas ou neutras, isto é, pode, por exemplo haver aumento, limitação ou manutenção do tamanho da população. Quando não há modificação do tamanho da população, pode haver mudança na estrutura da população como redução da quantidade de formas juvenis e de ovos. Assim, a redução da diversidade de espécies e a alteração da estrutura da população de alguns grupos da fauna edáfica podem representar um indicador de degradação do solo e de perda de sua sustentabilidade (Lopes Assad, 1997).

De modo geral, os organismos do solo são afetados por (Guerra et al., 1982; Brady, 1983; Almeida, 1985; Teixeira \& Schubart, 1988; Larink, 1997; Lopes Assad, 1997):

(a) compactação e seus efeitos na porosidade, na circulação de água e de ar e na mobilidade dos organismos no espaço poroso;

(b) profundidade de aração, que causa a inversão de distribuição da fauna, o deslocamento de resíduos de plantas e mudanças nas condições de crescimento microbiano;

(c) diminuição da qualidade e da quantidade de material orgânico e redução de abrigo ou locais para oviposição. A tendência é a redução da diversificação de espécies, principalmente a população total de organismos;

(d) destruição do revestimento vegetal do terreno, que causa flutuações microclimáticas e expõe os organismos aos excessos de temperatura (exposição do solo ao sol), à ciclos de umedecimento e secagem ( estresse hídrico prolongado e inundação) e ao fogo 
(mesmo que atingindo apenas a liteira), entre outros. Todos esses são fatores a que os habitantes do solo são sensíveis, com maior ou menor intensidade.

As principais conseqüências das ações que provocam profundos danos ao ambiente e à organização social, no que se refere ao funcionamento biodinâmico da cobertura pedológica, incluem: (a) eliminação direta e indireta da fauna do solo; (b) diminuição da porosidade biológica do solo, o que significa menor infiltração de água, maior erosão superficial, menor percolação de água até a rocha, menor velocidade de formação dos solos, menor transferência de argila para a superfície e maior acúmulo de areia residual (Miklós, 1998).

Os maiores efeitos do manejo podem ser vistos em regimes agrícolas anuais intensivos, onde a ausência de cobertura vegetal por muitos anos, o baixo retorno de matéria-orgânica, o revolvimento periódico do solo pelo uso de máquinas e o repetido uso de pesticidas podem resultar em progressivo esgotamento do teor de matéria orgânica do solo, deterioração estrutural e compactação do solo, erosão do solo e esgotamento de nutrientes, e redução na complexidade e estabilidade da comunidade biológica do solo (Curry \& Good, 1992). Nestes ambientes, a diversidade de organismos é geralmente menor que nas áreas cobertas por vegetação natural (Guerra et al., 1982), confirmando o efeito da floresta sobre a quantidade e qualidade da fauna do solo (Melo, 1984).

No caso de degradação moderada, basta a paralisação do cultivo para a fauna recuperar rapidamente os processos de sucessão, mas, de qualquer modo, a colonização natural de alguns grupos com baixo poder de dispersão pode ser lenta e o processo de estabelecimento da fauna pode ser facilitado por algumas medidas, como (a) limitação do baixo pH do solo; (b) retorno do "topsoil"; (c) correção orgânica para o fornecimento de substrato para decompositores, estabilização dos regimes de umidade e temperatura do solo; (d) estabelecimento de cobertura florestal, como Leguminosas, que são particularmente benéficas na fixação de $\mathrm{N}$ e na produção de resíduos de plantas de alta qualidade (Curry \& Good, 1992).

Portanto, produção ecologicamente aceitável, fertilização orgânica com adubo orgânico ou a distribuição de resíduos de plantas na superfície do solo e a redução ou não uso de práticas de revolvimento do solo são técnicas aconselháveis para criação de 
condições apropriadas para a proliferação e estabelecimento da fauna edáfica (Larink, 1997).

A definição da sustentabilidade de sistemas de produção exige que se considere, portanto, o papel da fauna no comportamento dos solos. A recuperação dos solos degradados não é possível pelos meios mecânicos isoladamente, é imprescindível a sua recuperação biológica, sem o quê, essa visão reducionista das complexas interações existentes no ambiente pode conduzir a degradação gradativa das terras antropizadas pela agricultura (Tibau, 1983; Lopes Assad, 1997). 


\section{MATERIAL E MÉTODOS}

\subsection{Caracterização climática da região}

As áreas utilizadas neste estudo pertencem à UNESP, situada na cidade de Botucatu (latitude de $22^{\circ} 88^{\prime} \mathrm{S}$ e longitude de $48^{\circ} 44^{\prime} \mathrm{W}$ ), região centro sul do Estado de São Paulo (Figura 1). O experimento foi instalado nas Fazendas Lageado e Edgárdia, que fazem parte da Faculdade de Ciências Agronômicas.

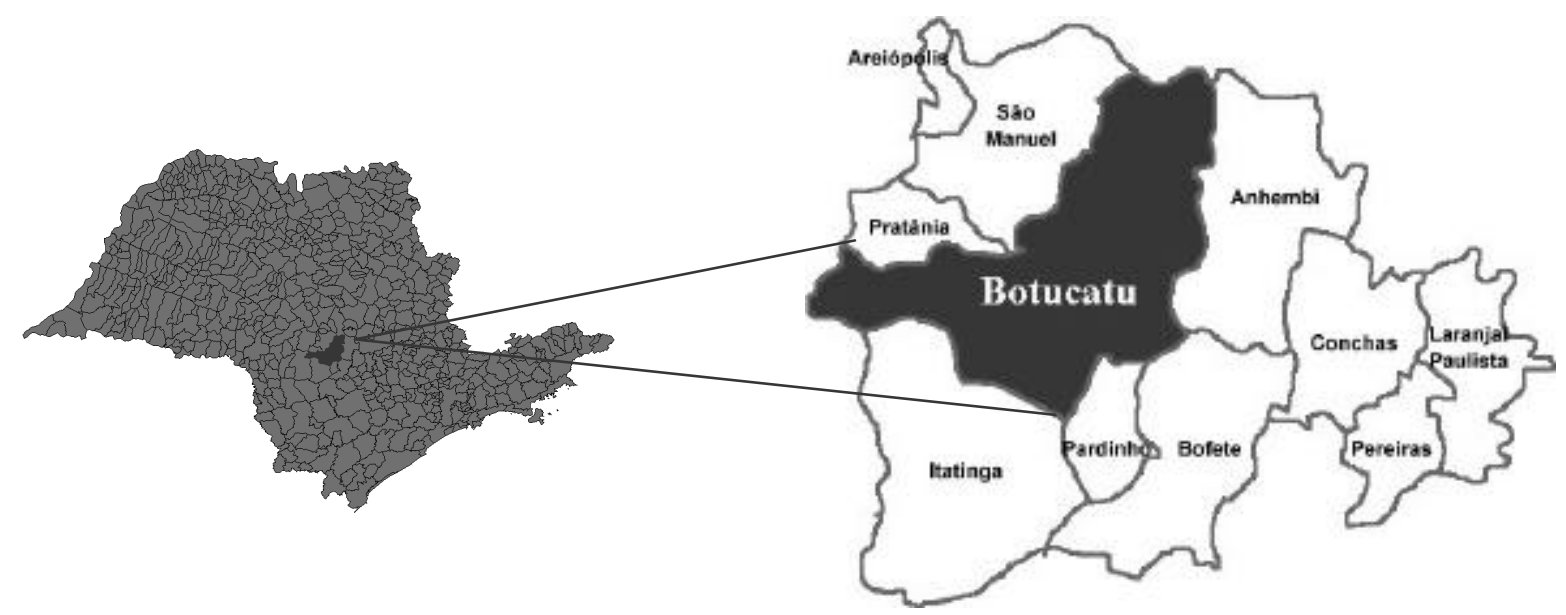

Figura 1 - Localização da região de Botucatu dentro do Estado de São Paulo (Guia de Botucatu, 2001).

O Escudo Atlântico originou parte da atual cobertura florística da região sudeste, e, por isso, a vegetação natural da região é tida como Floresta Estacional Semidecidual (Veloso et al., 1991) e se encontra dentro da área de domínio da Mata Attântica (Guia de Botucatu, 2001). As principais características desse tipo de vegetação são a presença de espécies arbóreas emergentes caducifólias e a existência de submata de arbustos (Veloso \& Góes Filho, 1982). 
O clima da região é subtropical úmido com invernos secos e verões quentes. Segundo a classificação de Köppen, a região se enquadra em dois tipos: CWA, depressão periférica ou baixada, caracterizado pelo clima mesotérmico úmido com inverno seco, em que a temperatura média do mês mais quente é maior que $22^{\circ} \mathrm{C}$, e CWB, no altiplano da cuesta onde está localizada a cidade, caracterizado por clima mesotérmico de inverno seco, em que as temperaturas médias do mês mais seco e mais frio é inferior a $18^{\circ} \mathrm{C}$ (Guia de Botucatu, 2001).

A precipitação média anual na região é de 1.533 mm (média de 1971 a 1998) e aproximadamente $74 \%$ desse total ocorre durante a estação úmida (outubro a março), com maior intensidade no mês de janeiro. Os meses com temperaturas médias mais amenas são junho e julho $\left(17,2^{\circ} \mathrm{C}\right)$, chegando a temperatura média mínima de $12,8 \mathrm{e}$ $13,0^{\circ} \mathrm{C}$, respectivamente. Em fevereiro, a temperatura média é de $23,4^{\circ} \mathrm{C}$ e chega a média máxima de $28,3^{\circ} \mathrm{C}$. A temperatura média anual é de $20,8^{\circ} \mathrm{C}$ (Figura 2).

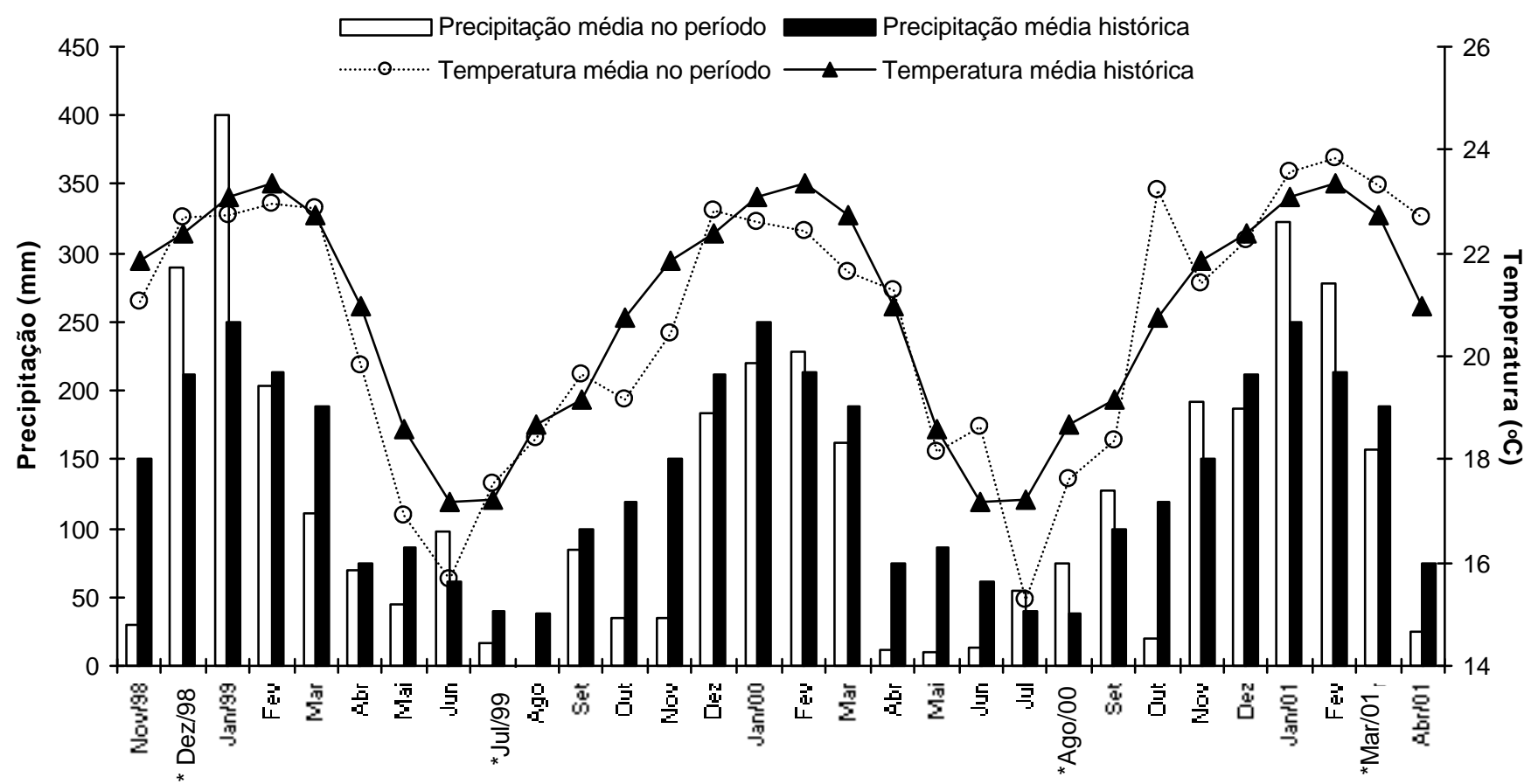

* Datas que correspondem às das coletas.

Figura 2 - Precipitação pluviométrica e temperaturas médias de novembro de 1998 a abril de 2001 e médias históricas (média de 28 anos), na Fazenda Lageado. 
O balanço hídrico da região, proposto por Thornthwaite-Mather (1955) e realizado com dados de 28 anos de análise, indica que há excedentes de água $(581 \mathrm{~mm}$ anualmente) em quase todos os meses do ano, exceto abril, julho e agosto. Há um pequeno déficit hídrico, de menos de 4 mm, apenas no mês de agosto. No ano de 1999 e 2000, época das amostragens, o regime hídrico diferiu do histórico em alguns aspectos, como a intensidade das chuvas que foi $242 \mathrm{~mm}$ menor e o déficit hídrico, que se manteve por cinco meses, chegando a $47 \mathrm{~mm}$ anuais.

Em relação à média histórica, a época de amostragem apresentou verão pouco mais seco, com menor excedente de água. O inverno, também mais seco, foi caracterizado pelo déficit hídrico em quase todo o período, aspecto não comum na região. Portanto, historicamente, a região não sofre com a falta de chuvas (Figura 3), mas na época de amostragem, o excedente hídrico se concentrou apenas nos meses de dezembro a março.

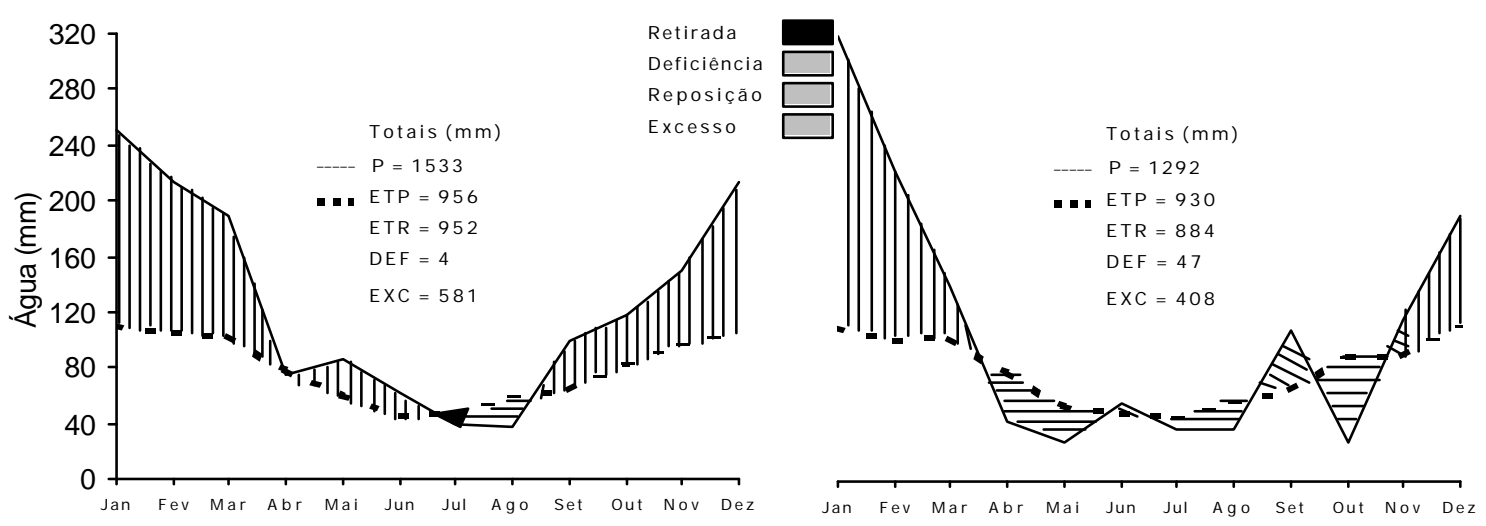

Figura 3 - Balanço Hídrico (THORNTHWAITE-MATHER - 1955) da Fazenda Lageado, em Botucatu, com: a) dados médios de 1971 a 1998 e b) dados médios de 1999 e 2000.

A evapotranspiração de $930 \mathrm{~mm}$ na época de amostragem foi muito próxima à da média anual histórica $(956 \mathrm{~mm})$, mas corresponde a uma maior percentagem de umidade perdida no total da precipitação anual (72\% contra $62 \%$ da média histórica), por causa da menor quantidade de chuvas. Estes valores assemelham-se ao relatado por Lima (1986), em que, do total de precipitação que chega anualmente em uma área, cerca de $70 \%$ retorna à atmosfera pela evapotranspiração, e também ao descrito por Arcova (1996), mostrando que em florestas tropicais, geralmente as perdas anuais pela evapotranspiração ultrapassam $1.000 \mathrm{~mm}$. 


\subsection{Caracterização ambiental das áreas experimentais}

O estudo foi estabelecido em áreas com três diferentes solos, duas situadas na Fazenda Edgárdia e uma na Fazenda Lageado. De acordo com Nogueira (2000), estas

áreas encontram-se junto a cuesta arenito-basáltica, com altitudes variando de 464 a $775 \mathrm{~m}$ :

(a) Área 1: Nitossolo Vermelho (NV)

Localizada a $700 \mathrm{~m}$ de altitude, é ocupada por Nitossolo Vermelho (NV) textura argilosa (Embrapa, 1999) e relevo ondulado. Do início do século até o fím da década de 60, a área foi utilizada para a produção de café; na década de 70 e 80 para a produção de feijão e, na década de 90, com plantios de capim napier (Pennisetum purpureum) (Nogueira Junior, 2000).

(b) Área 2: Argissolo Vermelho-Amarelo (PVA)

Localizada a $574 \mathrm{~m}$ de altitude, é ocupada por Argissolo Vermelho-Amarelo (PVA) Distrófico textura média, relevo suave ondulado a ondulado. A ocupação da área, desde 1920, foi dividida entre plantios de Citrus e pastagem de Brachiaria decumbens. No momento da instalação do experimento, foram retiradas as árvores ainda restantes do antigo pomar.

(c) Área 3: Latossolo Vermelho-Amarelo (LVA)

Localizada a $540 \mathrm{~m}$ de altitude, é ocupada por Latossolo Vermelho-Amarelo Distrófico textura areia franca, relevo plano a suave ondulado. Por aproximadamente 30 anos, a área foi utilizada como pastagem; depois, até 1980, como pomar de manga e pecã, e nos últimos 10 anos, o pomar foi abandonado e invadido por capim colonião (Panicum maximum). 


\subsection{Tratamentos e delineamento experimental}

Em cada área experimental, há cinco tratamentos instalados sobre as áreas revegetadas e um demarcado sobre floresta natural:

(a) Tratamento 1: Testemunha (Testemunha) - As parcelas experimentais, plantio de Citrus abandonado (PVA) e pastagens abandonadas (NV e LVA), foram apenas protegidas contra incêndios. Não houve plantio de nenhuma espécie florestal e a vegetação que se desenvolveu foi resultado da regeneração natural;

(b) Tratamento 2: Semeadura direta (Sem.Direta)- Neste tratamento, sementes de cinco espécies florestais heliófilas e de rápido crescimento (Chorisia speciosa, Croton floribundos, Enterolobium contorstisiliquum, Mimosa scabrela e Schizolobium parahyba) foram semeadas, depois de passarem pelo processo de quebra de dormência, no espaçamento de $1 \times 1 \mathrm{~m}$ e a $5 \mathrm{~cm}$ de profundidade. Com duas a quatro sementes por cova, o número de plântulas chegou, aproximadamente, a $4000 \mathrm{ha}^{-1}$;

(c) Tratamento 3: Sistema Taungya modificado (Taungya) - Nesse sistema, utilizou-se o plantio de espécies florestais em linhas triplas, intercalado com faixas de $5 \mathrm{~m}$ utilizadas para culturas anuais. As 19 espécies florestais (Tabela 1) foram plantadas com espaçamento de 1,5 m entre plantas e $2 \mathrm{~m}$ entre as linhas. As linhas externas foram compostas por 11 espécies de uso múltiplo e de rápido crescimento (grupo A e B), e na linha central foram semeadas oito espécies de valor comercial e crescimento mais lento (grupo C). Como culturas anuais, foram cultivados feijão e milho no NV, milho e mandioca no PVA e batata-doce e abóbora no LVA. Estas culturas foram definidas com base na época de plantio e características de cada solo, que foram preparados e adubados convencionalmente; 
(d) Tratamento 4: Consorciação de espécies nativas de rápido crescimento com espécies comerciais para madeira (Pioneira/Tardia) - Foram utilizadas mudas de nove espécies do grupo A e B e 14 espécies do grupo C (Tabela 1), plantadas em linhas alternadas com espaçamento de $2 \mathrm{~m}$ entre linhas e 1,5 m entre plantas;

(e) Tratamento 5: Mistura de espécies nativas em modelos de plantio-restauração (Restauração) - Neste tratamento, foram utilizadas espécies remanescentes típicas da Mata Atlântica presentes na região (Tabela 1). As 31 espécies utilizadas são pertencentes a diferentes grupos ecológicos (grupo A: cinco espécies; grupo B: oito espécies; grupo C: 13 espécies; grupo D: cinco espécies). Foram testados, neste tratamento, dois espaçamentos diferentes: 1,5 x 1,5 m e 3,0 x 2,0 m;

(f) Tratamento 6: Fragmentos Florestais (Fragmento) - Como referência, foram demarcadas parcelas em solos sob fragmentos florestais de mata nativa, localizados sempre ao lado das áreas experimentais.

\section{Fragmentos florestais}

NV: O fragmento florestal, com cerca de 50-60 m de largura, ao longo do rio Lavapés, exerce a função de mata ciliar e encontra-se degradado. A altura aproximada do dossel é de 15-18 m (Figura 4a).

PVA: Nesta área, existe fragmento com cerca de 250 ha de mata primária, que sofreu extração seletiva de madeira até cerca de 20 anos atrás. A altura das árvores dominantes é de 25-30 m, e ocorre maior diversidade de espécies arbóreas e de outras formas de vida (epífitas, arbustos, etc.) que nos demais fragmentos (Figura 5b).

LVA: Com cerca de 50 ha, o fragmento de floresta secundária encontra-se em estágio médio a avançado de sucessão, recuperando-se do fogo que atingiu a área a cerca de 15 anos atrás. A altura do dossel é de cerca de 15-20 m e há grande presença de árvores leguminosas (Fabaceae e Mimosaceae), que formam cerca de $70 \%$ do dossel superior (Figura 4c). 


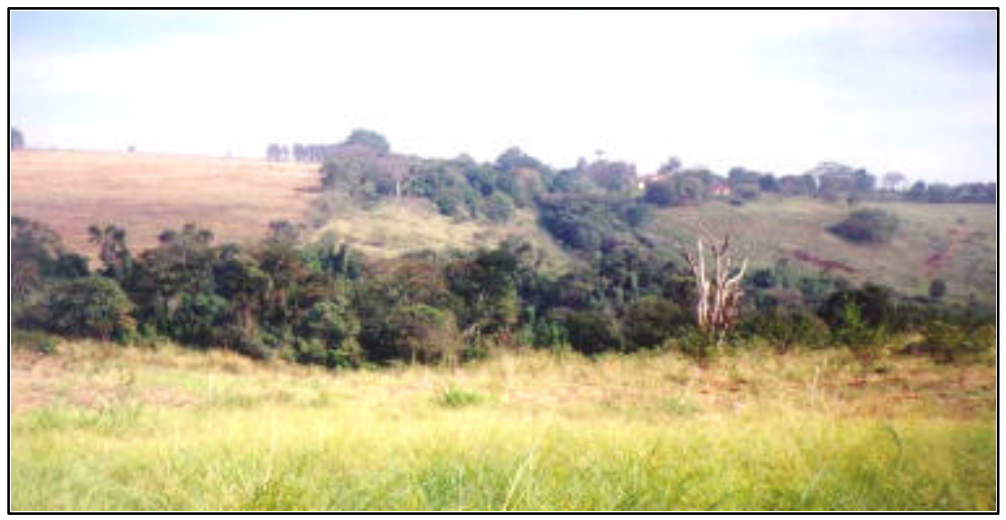

(a)

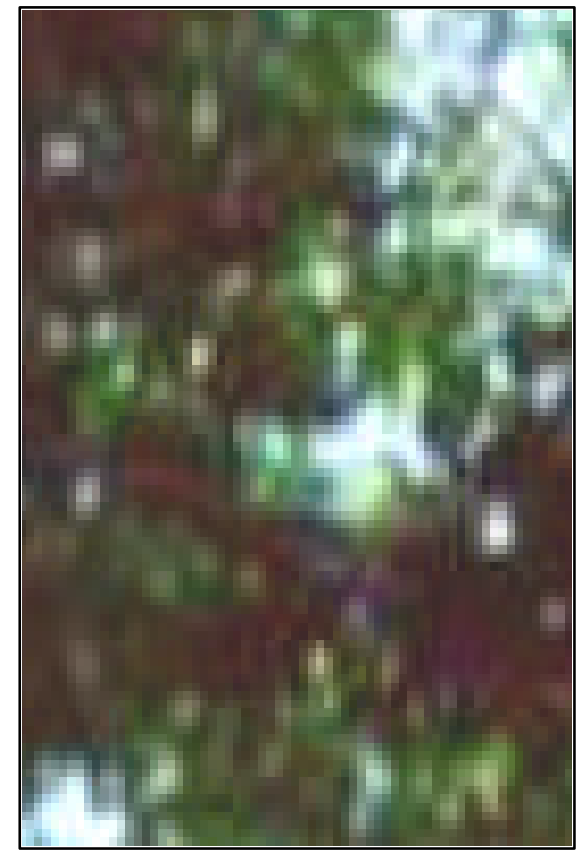

(b)

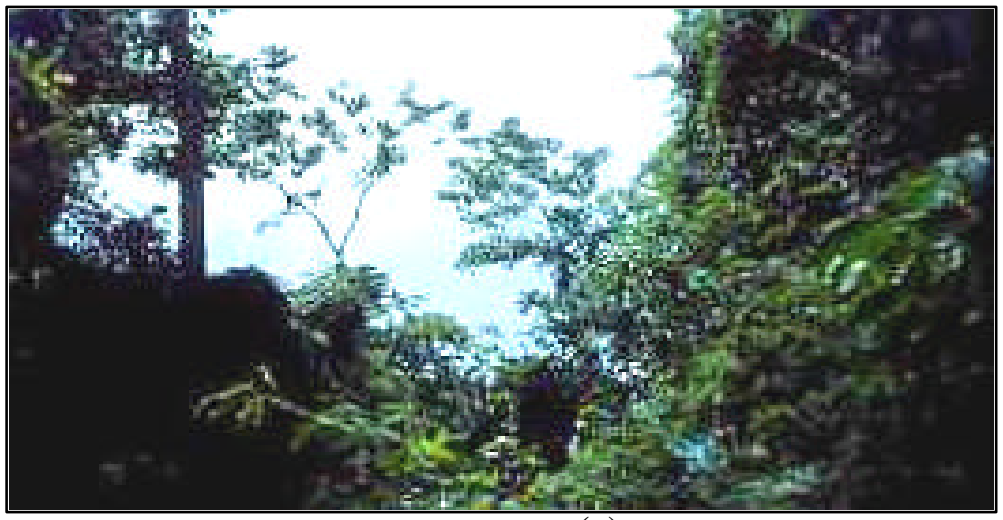

(c)

Figura 4 - Vista geral do Fragmento Florestal do (a) NV, (b) PVA e (b) LVA. 
Nas Figuras 5, 6 e 7 podem ser comparados o estabelecimento do plantio no início da experimentação e seu desenvolvimento no último período de amostragem.

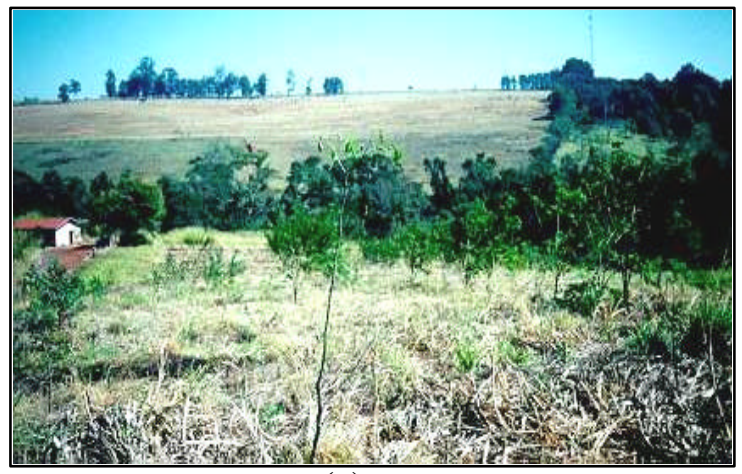

(a)

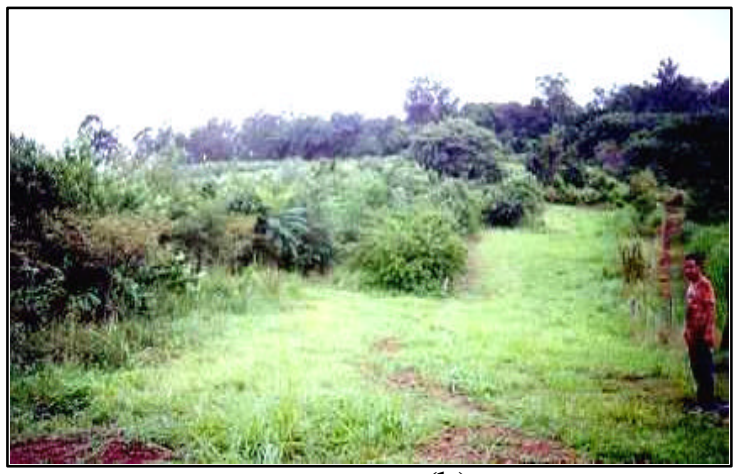

(b)

Figura 5 - Vista geral do NV em (a) julho de 1999 e (b) março de 2001.

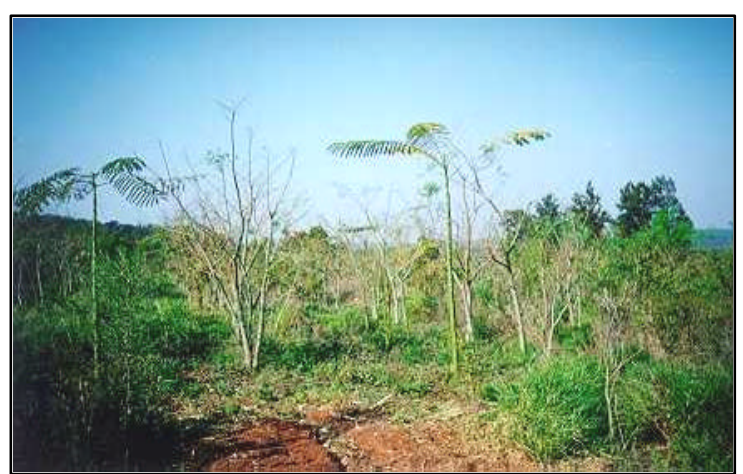

(a)

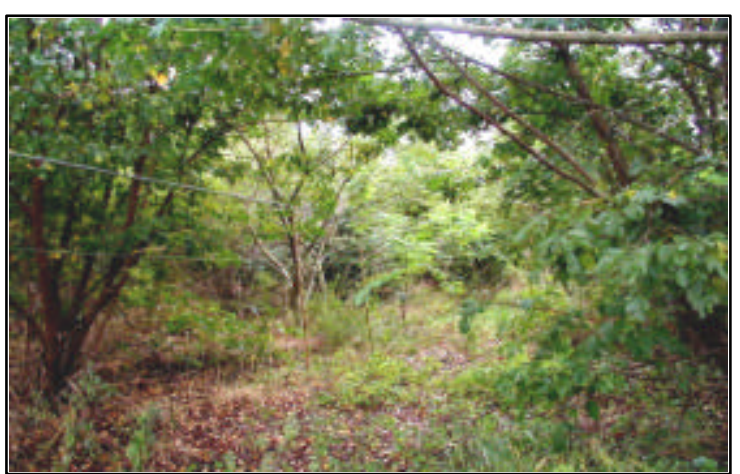

(b)

Figura 6 - Vista geral do PVA em (a) julho de 1999 e (b) março de 2001.

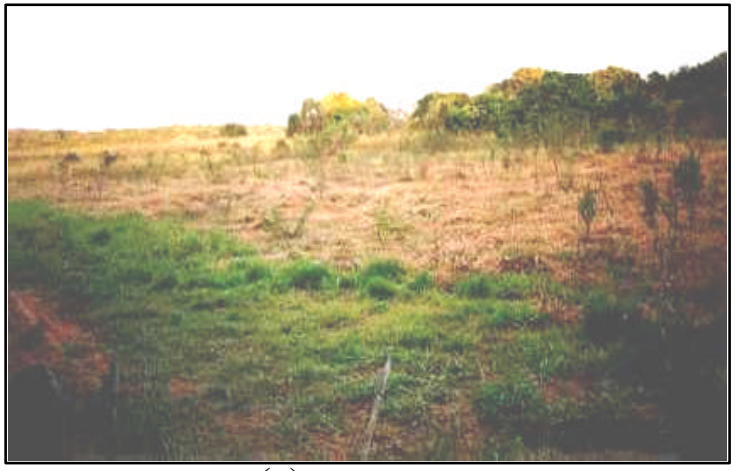

(a)

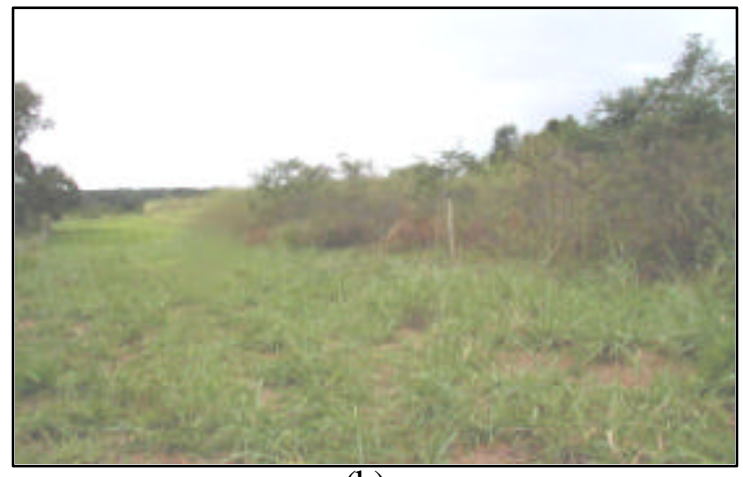

(b)

Figura 7 - Vista geral do LVA em (a) julho de 1999 e (b) março de 2001. 
Tabela 1. Grupo, família, nome científico, vulgar e indivíduos/parcela das espécies utilizadas nas associações de espécies dos tratamentos ${ }^{2}$.

\begin{tabular}{|c|c|c|c|c|c|c|}
\hline \multirow[b]{2}{*}{ Grupo } & \multirow[b]{2}{*}{ Família } & \multicolumn{2}{|l|}{ Nome } & \multicolumn{3}{|c|}{ Indivíduos/parcela } \\
\hline & & Científico & Vulgar & Taungya & $\begin{array}{c}\text { Pioneira/ } \\
\text { Tardia }\end{array}$ & Restauração \\
\hline A & Anacardiaceae & Schinus terebinthifolius & Aroeira pimenteira & - & - & 44 \\
\hline A & Euphorbiaceae & Croton floribundus & Capixingui & - & - & 50 \\
\hline A & Leguminosae & Enterolobium contorstisiliquum & Tamboril & 10 & 52 & 53 \\
\hline A & Leguminodae & Anadenanthera colubrina & Angico-branco & 60 & 78 & - \\
\hline A & Leguminosae & Ingá uruguensis & Ingá & 10 & - & - \\
\hline A & Leguminosae & Mimosa caesalpinaefolia & Sansão do campo & 30 & 26 & - \\
\hline A & Leguminosae & Mimosa scabrela & Bracatinga & 90 & 78 & - \\
\hline A & Myrtaceae & Eugenia pyriformis & Uvaia & - & - & 20 \\
\hline A & Sterculariaceae & Guazuma ulmifolia & Mutamba & 40 & 26 & 46 \\
\hline B & Bombacaceae & Chorisia speciosa & Paineira & - & - & 28 \\
\hline B & Leguminosae & Peltophorum dubium & Canafístula & 10 & 13 & - \\
\hline B & Leguminosae & Piptadenia gonoacantha & Pau-jacaré & 10 & 13 & 10 \\
\hline B & Leguminosae & Pterogyne nitens & Amendoim bravo & 40 & 39 & 28 \\
\hline B & Leguminosae & Schizolobium parahyba & Guapuruvu & - & - & 28 \\
\hline B & Rubiaceae & Genipa americana & Genipapo & - & - & 22 \\
\hline B & Tiliaceae & Luehea divaricata & Açoita-cavalo & - & - & 10 \\
\hline B & Verbenaceae & Citharexylum myrianthum & Pau-viola & - & - & 44 \\
\hline B & Euphorbiacae & Pera glabrata & Tamanqueira & 10 & - & 33 \\
\hline B & Leguminosae & Machaerium villosum & Jacarandá do campo & 30 & 26 & - \\
\hline $\mathrm{C}$ & Bignoniaceae & Zeyheiria tuberculosa & Ipê felpudo & 50 & 65 & 17 \\
\hline $\mathrm{C}$ & Apocynaceae & Aspidosperma polyneuron & Peroba rosa & 15 & 26 & 20 \\
\hline $\mathrm{C}$ & Apocynaceae & Aspidosperma ramiflorum & Guatambu & 10 & 13 & - \\
\hline $\mathrm{C}$ & Bignoniaceae & Tatebuia aveilanedas & Ipê-roxo & - & 13 & - \\
\hline $\mathrm{C}$ & Lecythidaceae & Cariniana estrellensis & Jequitibá-branco & - & - & 10 \\
\hline $\mathrm{C}$ & Lecythidaceae & Cariniana legalis & Jequitibá-vermelho & - & 13 & - \\
\hline $\mathrm{C}$ & Leguminosae & Copaifera longedorfii & Copaíba & 10 & 13 & 10 \\
\hline $\mathrm{C}$ & Leguminosae & Dalbergia nigra & Jacarandá da Bahia & - & 13 & - \\
\hline $\mathrm{C}$ & Leguminosae & Dipteryx alata & Cumbaru & - & - & 17 \\
\hline $\mathrm{C}$ & Leguminosae & Hymenea courbaril( stilbocarpa) & Jatobá & 30 & 39 & 20 \\
\hline $\mathrm{C}$ & Leguminosae & Myroxylum peruiferum & Cabreúva & - & 13 & - \\
\hline $\mathrm{C}$ & Leguminosae & Parapiptadenia rigida & Angico vermelho & - & 26 & 10 \\
\hline $\mathrm{C}$ & Leguminosae & Poecilanthe parviflora & Coração-de-negro & - & - & 10 \\
\hline $\mathrm{C}$ & Meliaceae & Cedrella fissilis & Cedro & 20 & 13 & 20 \\
\hline $\mathrm{C}$ & Rutaceae & Enzenbeckia leiocarpa & Guarantã & 20 & 52 & 20 \\
\hline $\mathrm{C}$ & Rutaceae & Balfourodendron riedelianum & Pau-marfim & - & 26 & 20 \\
\hline $\mathrm{C}$ & Sapotaceae & Pouteria ramiflroa & Grão-de-galo & - & - & 18 \\
\hline $\mathrm{C}$ & Arecaceae & Euterpe edulis & Palmito branco & 10 & 13 & 27 \\
\hline $\mathrm{D}$ & Meliaceae & Trichilia pallens & catiguá & - & - & 10 \\
\hline $\mathrm{D}$ & Boraginaceae & Cordia superba & Baba de boi & - & - & 47 \\
\hline $\mathrm{D}$ & Leguminosae & Ormosia arborea & Olho de cabra & - & - & 10 \\
\hline $\mathrm{D}$ & Myrtaceae & Eugenia uniflora & Pitanga vermelha & - & - & 18 \\
\hline $\mathrm{D}$ & Rutaceae & Metrodorea stipularis & Chupa-ferro & - & - & 24 \\
\hline
\end{tabular}

Fonte: Nogueira Junior (2000). 
Cada parcela experimental teve dimensões de 50 x $50 \mathrm{~m}\left(2.500 \mathrm{~m}^{2}\right)$, distribuídas na área no delineamento de blocos casualizados, com três repetições. No total, o experimento possuiu 4,5 ha em cada solo.

\subsection{Instalação e manutenção do experimento}

Os tratamentos utilizados no experimento foram definidos e instalados antes da realização do estudo sobre a meso e macrofauna edáfica. No início deste trabalho, o plantio realizado com a semeadura direta das plantas estava com cerca de 20 meses de idade e, os demais tratamentos, 10 meses.

Para a implantação dos tratamentos, em fevereiro de 1997, a área total foi preparada com rolo-faca no NV e, roçada mecanizada, no PVA e LVA. Em todas as áreas, foi feita aplicação mecanizada de herbicida e marcação das parcelas do tratamento Sem.Direta. As sementes utilizadas nas parcelas do Sem.Direta passaram pela quebra de dormência e foram semeadas em março de 1997 em covas de cerca de $40 \mathrm{~cm}$ de profundidade. Em seguida, foi feito combate à formiga, roçada manual (maio de 1997) e aplicação manual de herbicida (julho de 1997), para o controle de plantas invasoras.

Em novembro e dezembro de 1997, o solos das áreas onde foram instalados os tratamentos Taungya, Pioneira/Tardia e Restauração foram preparados convencionalmente, com aração, gradagem leve e abertura manual de covas. As parcelas foram instaladas em janeiro e fevereiro de 1998, dez meses após a instalação do Sem.Direta. O solo do tratamento Testemunha, que não sofreu preparo do solo, foi demarcado nesta mesma época. As parcelas sob o Fragmento foram as últimas a serem demarcadas, de março a junho de 1998.

Como práticas de controle de plantas invasoras, foi realizada mva roçada manual no Sem.Direta em abril de 1998 e nos demais tratamentos em julho de 1998. De setembro a outubro de 1998, foi feita aplicação manual de herbicida em área total e combate à formiga nos tratamentos Taungya, Pioneira/Tardia e Restauração. Nas áreas de cultura agrícola, foi realizado o cultivo de milho no NV e PVA, após a preparação do solo com aragem, enxada rotativa e calagem. 
Em 1999, foram efetuadas capinas manuais no NV em maio e junho, e aplicação de herbicida (glifosato, cerca de $3 \mathrm{~L} \mathrm{ha}^{-1}$ ) no mês de agosto. No LVA, a capina manual foi realizada em julho de 1999, visando o controle do capim colonião e da braquiária. No Taungya dos três solos, o plantio de feijão foi feito em março e, de milho, em outubro de 1999, após o preparo de solo com enxada rotativa, calagem e adubação nas faixas de culturas.

Em todas as áreas, foi realizada roçada manual em julho de 2000 e pulverização localizada (costal manual) de herbicida em setembro, com repasse em outubro. O replantio de mudas foi realizado em novembro do mesmo ano, em todas as áreas. As culturas agrícolas semeadas, após novo preparo do solo, foram feijão, mandioca e abóbora nos solos NV, PVA e LVA, respectivamente.

Foi necessário novo replantio de mudas de canafístula e bracatinga no LVA (março de 2001) e, pulverização localizada de herbicida e combate à formigas nas três áreas. A implantação de culturas agrícolas no Taungya foi realizada em dezembro de 2001 a janeiro de 2002 .

\subsection{Caracterização dos atributos do solo}

\subsubsection{Temperatura do solo}

Em cada área experimental, foi observada a temperatura do solo dos Fragmentos e do interior das áreas revegetadas. As três repetições foram realizadas no período da tarde, entre 12:00 e 14:00 horas, durante a amostragem da fauna edáfica. Para tanto, foi utilizado o psicrômetro, a uma profundidade de $5 \mathrm{~cm}$.

\subsubsection{Umidade do solo}

Durante as amostragem da fauna edáfica, foram retiradas três amostras de solo a $15 \mathrm{~cm}$ de profundidade por tratamento, uma por parcela. Foram separadas $150 \mathrm{~g}$ de solo por amostra, totalizando $450 \mathrm{~g}$ de solo por tratamento. A umidade do solo (\%) foi 
calculada com a determinação do peso da amostra seca, obtida após a secagem em estufa a uma temperatura de $45^{\circ} \mathrm{C}$ por aproximadamente 48 horas, até o peso se tornar constante.

\subsection{Caracterização da meso e macrofauna edáfica}

Para a caracterização e identificação da fauna edáfica, foram realizadas amostragens em dois períodos: úmido (verão) e seco (inverno). Estas avaliações foram executadas semestralmente em todos os tratamentos. Na primeira amostragem, apenas os tratamentos Sem.Direta e Fragmento foram inventariados isoladamente; os demais tratamentos (Testemunha, Taungya, Pioneira/Tardia e Restauração) foram considerados como um só e denominado de "Demais Trat", pois foram instalados na mesma época, com condições semelhantes. Nas demais amostragens, todos os tratamentos foram analisados separadamente.

$\mathrm{O}$ tratamento chamado de Revegetação correspondeu à média da fauna encontrada nos cinco tratamentos instalados sobre as áreas revegetadas (Testemunha, Sem. Direta, Taungya, Pioneira/Tardia e Restauração) e foi incluído na pesquisa para comparação entre os resultados obtidos no Fragmento Florestal e na área revegetada.

\subsubsection{Mesofauna edáfica}

Para a caracterização da mesofauna do solo, foram coletadas quatro amostras (solo e serapilheira) por parcela, com distâncias entre pontos de amostragem de $12,5 \mathrm{~m}$ entre si ao longo de um transecto de $250 \mathrm{~m}$ nas áreas revegetadas e ,com distâncias de $5 \mathrm{~m}$ ao longo de um transecto de $100 \mathrm{~m}$ nos Fragmentos. As 12 amostras simples de cada tratamento foram colhidas a $5 \mathrm{~cm}$ de profundidade, utilizando-se uma sonda de aço inoxidável com cilindro de PVC de $5 \mathrm{~cm}$ de diâmetro embutido. Particularmente no tratamento Taungya, tomou-se o cuidado de não coletar amostras de solo das linhas onde foram plantadas 
culturas agrícolas anuais. Sem que se separassem, os cilindros e as amostras foram acondicionados em sacos plásticos individuais e identificados.

No laboratório, a mesofauna foi extraída pelo método de Berleusse - Tullgren modificado, por meio de um equipamento adaptado (Oliveira, 1999) composto por caixas retangulares de compensado (Figura 8), contendo 21 lâmpadas de $25 \mathrm{~W}$ que atuaram como fonte de luz e calor, fazendo com que os componentes da mesofauna migrassem para baixo, caindo em solução de álcool $80 \%$. As amostras foram mantidas no extrator por 96 h expostas à luz, mantendo-se a temperatura do ambiente interno (acima dos potes) em $50^{\circ} \mathrm{C}$ e a temperatura nos potes de coleta em $42^{\circ} \mathrm{C}$.

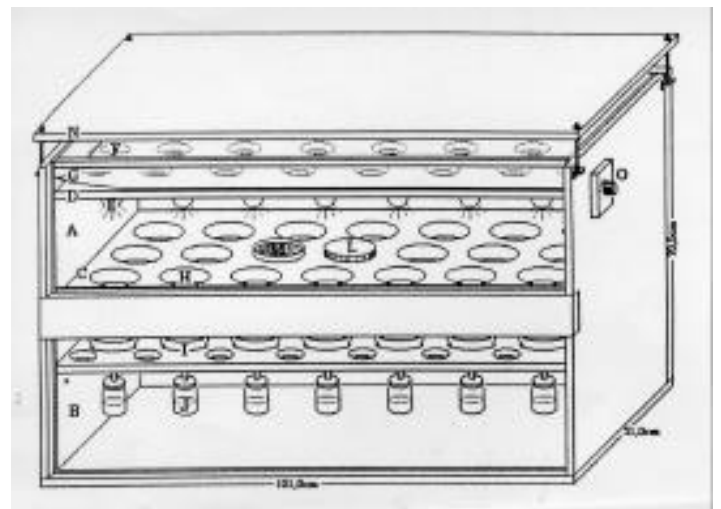

Figura 8 - Caixa extratora de ácaros do solo. Fonte: Oliveira (1999).

Depois de acondicionada, a mesofauna capturada passou pelo processo de identificação e contagem com a ajuda de uma lupa binocular.

Os organismos identificáveis pertenciam à classe de ácaros (Arachnida: Acari) e foram classificados em grupos de mesma subordem.

\subsubsection{Macrofauna de invertebrados}

Dez amostras de solo por parcela foram retiradas na forma de monolitos cilíndricos com 7,5 cm de diâmetro e $15 \mathrm{~cm}$ de altura. Os pontos de amostragens ficaram distanciadas entre si em $25 \mathrm{~m}$ ao longo de um transecto de $250 \mathrm{~m}$ nas áreas revegetadas e, 
com distâncias entre si de 10 m, ao longo de um transecto de 100 m nos Fragmentos. Como ocorrido para a mesofauna, no tratamento Taungya, as amostras de solo foram retiradas das Inhas de plantio florestal. Após a coleta, as amostras foram acondicionadas em sacos plásticos individuais e etiquetadas. No laboratório, a catação foi manual, a olho $\mathrm{nu}$, com pinças e pincéis. Os organismos foram acondicionados em recipiente contendo álcool $(80 \%)$ para posterior classificação.

O termo "Grupo" foi utilizado para identificar os invertebrados de uma mesma família (Formicidae), Ordem (Coleoptera) ou classe (Diplopoda). Os grupos de macrorganismos com quantidades inferiores aos demais foram reunidos em um único grupo denominado de "Outros".

\subsection{Análise estatística}

Para a padronização dos dados, o número de indivíduos encontrado em cada amostra foi transformado em número de indivíduos por metro quadrado (densidade). Os dados de densidade total de organismos nos diferentes tratamentos foram analisados estatisticamente pelo teste de Friedman, que emprega análises de variância nãoparamétrica, tanto para discriminar os tratamentos como para as comparações múltiplas das médias. Foi utilizado esta técnica porque as variáveis, apesar de quantitativas $\left(\mathrm{n}^{\mathrm{0}} \mathrm{de}\right.$ indivíduos capturados), são de origem discreta, não-paramétricas. Com a finalidade de agrupar os tratamentos que possuíam maior grau de similaridade para a densidade de organismos, fez-se análise multivariada dos dados, utilizando a técnica de Agrupamento de Cluster (Cluster Analysis - Programa Statgraphics Plus 2.1). 


\section{RESULTADOS E DISCUSSÃO}

\subsection{Acarofauna edáfica}

As condições diferenciadas dos ambientes estudados, devidas ao tipo de solo e cobertura vegetal, não influenciaram estatisticamente a densidade de ácaros nos três solos (NV, PVA e LVA), em nenhuma época amostral. A aceitação da hipótese de independência (5\% de probabilidade) do Teste de Friedman revelou que, quanto à densidade total de ácaros nos primeiros $5 \mathrm{~cm}$ do solo, os tratamentos utilizados no experimento não diferem entre si (Tabela 2).

Tabela 2. Valores obtidos pelo Teste de Friedman para a densidade de ácaros em cada época de amostragem.

\begin{tabular}{lcccc}
\hline Solo & Dez/98 & Jul/99 & Ago/00 & Mar/01 \\
\hline NV & 0,67 & 2,07 & $9,56^{*}$ & 0,84 \\
PVA & 2,00 & $9,95^{*}$ & 6,86 & $9,79^{*}$ \\
LVA & 0,67 & $9,56^{*}$ & $10,99^{*}$ & 4,29 \\
\hline * = Significativo pelo teste de Friedman, a 10\% de probabilidade. Nenhum valor foi significativo a 5\% de probabilidade.
\end{tabular}

Mesmo não existindo diferenças significativas entre tratamentos a 5\% de probabilidade de erro, o Fragmento pode ser indicado como melhor tratamento, pois em números absolutos, a densidade total de ácaros capturados neste tratamento foi superior aos outros tratamentos e à Revegetação nas duas últimas amostragens no NV (Tabela 3) e em todas as amostragens no PVA e LVA (Tabelas 4 e 5). Em dez/98 e em jul/99, as maiores densidades de ácaros no NV foram observadas no "Demais Trat." e Sem.Direta, respectivamente (Tabela 3). 
Tabela 3. Densidades observadas (média \pm erro-padrão) para a ocorrência de subordens de ácaros no NV, nos diferentes tratamentos e épocas de amostragem.

\begin{tabular}{|c|c|c|c|c|c|}
\hline \multirow[b]{2}{*}{ Tratamento } & \multicolumn{4}{|c|}{ Subordem de Ácaros } & \multirow[b]{2}{*}{ Total } \\
\hline & Oribatida & Mesostigmata & Astigmata & Prostigmata & \\
\hline & \multicolumn{5}{|c|}{ Número de indivíduos $\mathrm{m}^{-2}$} \\
\hline & \multicolumn{5}{|c|}{ Primeira amostragem (Dez/98) } \\
\hline Demais Trat. & $1.403 \pm 145$ & $500 \pm 96$ & $56 \pm 32$ & $0 \pm 0$ & $1.959 \pm 21$ \\
\hline Sem.Direta & $1.083 \pm 173$ & $472 \pm 182$ & $112 \pm 91$ & $0 \pm 0$ & $1.666 \pm 421$ \\
\hline Fragmento & $694 \pm 227$ & $597 \pm 241$ & $56 \pm 56$ & $0 \pm 0$ & $1.347 \pm 337$ \\
\hline Revegetação & $1.243 \pm 132$ & $486 \pm 60$ & $84 \pm 16$ & $0 \pm 0$ & $1.813 \pm 195$ \\
\hline \multirow[t]{2}{*}{ Média } & $1060 \pm 156$ & $523 \pm 72$ & $74 \pm 28$ & $0 \pm 0$ & $1.657 \pm 195$ \\
\hline & \multicolumn{5}{|c|}{ Segunda amostragem $(\mathrm{Jul} / 99)$} \\
\hline Testemunha & $333 \pm 42$ & $250 \pm 72$ & $125 \pm 72$ & $0 \pm 0$ & $708 \pm 42$ \\
\hline Sem.Direta & $375 \pm 191$ & $333 \pm 110$ & $42 \pm 42$ & $0 \pm 0$ & $750 \pm 260$ \\
\hline Taungya & $250 \pm 72$ & $208 \pm 110$ & $42 \pm 42$ & $0 \pm 0$ & $500 \pm 191$ \\
\hline Pioneira/Tardia & $333 \pm 150$ & $167 \pm 42$ & $42 \pm 42$ & $0 \pm 0$ & $542 \pm 182$ \\
\hline Restauração & $292 \pm 182$ & $167 \pm 42$ & $0 \pm 0$ & $0 \pm 0$ & $458 \pm 182$ \\
\hline Fragmento & $250 \pm 72$ & $250 \pm 72$ & $42 \pm 42$ & $0 \pm 0$ & $542 \pm 150$ \\
\hline Revegetação & $317 \pm 60$ & $225 \pm 38$ & $50 \pm 38$ & $0 \pm 0$ & $592 \pm 84$ \\
\hline \multirow[t]{2}{*}{ Média } & $306 \pm 42$ & $229 \pm 21$ & $49 \pm 28$ & $0 \pm 0$ & $583 \pm 48$ \\
\hline & \multicolumn{5}{|c|}{ Terceira amostragem (Ago/00) } \\
\hline Testemunha & $125 \pm 72$ & $167 \pm 110$ & $83 \pm 83$ & $42 \pm 42$ & $417 \pm 110$ \\
\hline Sem.Direta & $125 \pm 0$ & $83 \pm 42$ & $0 \pm 0$ & $0 \pm 0$ & $208 \pm 42$ \\
\hline Taungya & $208 \pm 150$ & $167 \pm 83$ & $42 \pm 42$ & $0 \pm 0$ & $417 \pm 167$ \\
\hline Pioneira/Tardia & $125 \pm 72$ & $42 \pm 42$ & $0 \pm 0$ & $42 \pm 42$ & $208 \pm 110$ \\
\hline Restauração & $208 \pm 42$ & $125 \pm 72$ & $0 \pm 0$ & $42 \pm 42$ & $375 \pm 72$ \\
\hline Fragmento & $208 \pm 42$ & $167 \pm 83$ & $83 \pm 42$ & $42 \pm 42$ & $500 \pm 191$ \\
\hline Revegetação & $158 \pm 22$ & $117 \pm 44$ & $25 \pm 14$ & $25 \pm 0$ & $325 \pm 43$ \\
\hline \multirow[t]{2}{*}{ Média } & $167 \pm 12$ & $125 \pm 42$ & $35 \pm 18$ & $28 \pm 7$ & $354 \pm 52$ \\
\hline & \multicolumn{5}{|c|}{ Quarta amostragem (Mar/01) } \\
\hline Testemunha & $208 \pm 110$ & $125 \pm 125$ & $125 \pm 72$ & $0 \pm 0$ & $458 \pm 253$ \\
\hline Sem.Direta & $125 \pm 125$ & $83 \pm 83$ & $125 \pm 72$ & $0 \pm 0$ & $333 \pm 150$ \\
\hline Taungya & $125 \pm 125$ & $83 \pm 83$ & $83 \pm 83$ & $0 \pm 0$ & $292 \pm 42$ \\
\hline Pioneira/Tardia & $208 \pm 150$ & $167 \pm 110$ & $42 \pm 42$ & $42 \pm 42$ & $458 \pm 273$ \\
\hline Restauração & $42 \pm 42$ & $167 \pm 42$ & $83 \pm 83$ & $0 \pm 0$ & $292 \pm 83$ \\
\hline Fragmento & $250 \pm 125$ & $125 \pm 72$ & $125 \pm 72$ & $83 \pm 42$ & $583 \pm 208$ \\
\hline Revegetação & $142 \pm 55$ & $125 \pm 52$ & $92 \pm 44$ & $8 \pm 8$ & $367 \pm 131$ \\
\hline Média & $160 \pm 60$ & $125 \pm 48$ & $97 \pm 49$ & $21 \pm 12$ & $403 \pm 143$ \\
\hline
\end{tabular}


Tabela 4. Densidades observadas (média \pm erro-padrão) para a ocorrência de subordens de ácaros no PVA, nos diferentes tratamentos e épocas de amostragem.

\begin{tabular}{|c|c|c|c|c|c|}
\hline \multirow[b]{2}{*}{ Tratamento } & \multicolumn{4}{|c|}{ Subordem de Ácaros } & \multirow[b]{2}{*}{ Total } \\
\hline & Oribatida & Mesostigmata & Astigmata & Prostigmata & \\
\hline & \multicolumn{5}{|c|}{ Número de indivíduos $\mathrm{m}^{-2}$} \\
\hline & \multicolumn{5}{|c|}{ Primeira amostragem (Dez/98) } \\
\hline Demais Trat. & $417 \pm 210$ & $458 \pm 105$ & $0 \pm 0$ & $0 \pm 0$ & $875 \pm 315$ \\
\hline Sem.Direta & $389 \pm 200$ & $625 \pm 134$ & $111 \pm 111$ & $0 \pm 0$ & $1.125 \pm 421$ \\
\hline Fragmento & $861 \pm 73$ & $847 \pm 97$ & $0 \pm 0$ & $0 \pm 0$ & $1.708 \pm 64$ \\
\hline Revegetação & $403 \pm 157$ & $542 \pm 87$ & $56 \pm 56$ & $0 \pm 0$ & $1.000 \pm 255$ \\
\hline \multirow[t]{2}{*}{ Média } & $556 \pm 116$ & $644 \pm 70$ & $37 \pm 37$ & $0 \pm 0$ & $1.236 \pm 187$ \\
\hline & \multicolumn{5}{|c|}{ Segunda amostragem (Jul/99) } \\
\hline Testemunha & $292 \pm 42$ & $125 \pm 0$ & $42 \pm 42$ & $0 \pm 0$ & $458 \pm 83$ \\
\hline Sem.Direta & $458 \pm 42$ & $125 \pm 72$ & $0 \pm 0$ & $0 \pm 0$ & $583 \pm 42$ \\
\hline Taungya & $167 \pm 110$ & $125 \pm 0$ & $0 \pm 0$ & $0 \pm 0$ & $292 \pm 110$ \\
\hline Pioneira/Tardia & $208 \pm 110$ & $83 \pm 42$ & $0 \pm 0$ & $0 \pm 0$ & $292 \pm 150$ \\
\hline Restauração & $125 \pm 72$ & $167 \pm 83$ & $0 \pm 0$ & $0 \pm 0$ & $292 \pm 42$ \\
\hline Fragmento & $542 \pm 167$ & $375 \pm 144$ & $0 \pm 0$ & $0 \pm 0$ & $917 \pm 220$ \\
\hline Revegetação & $250 \pm 14$ & $125 \pm 25$ & $8 \pm 8$ & $0 \pm 0$ & $383 \pm 22$ \\
\hline \multirow[t]{2}{*}{ Média } & $299 \pm 18$ & $167 \pm 32$ & $7 \pm 7$ & $0 \pm 0$ & $472 \pm 54$ \\
\hline & \multicolumn{5}{|c|}{ Terceira amostragem (Ago/00) } \\
\hline Testemunha & $125 \pm 72$ & $83 \pm 42$ & $0 \pm 0$ & $0 \pm 0$ & $208 \pm 110$ \\
\hline Sem.Direta & $208 \pm 83$ & $83 \pm 42$ & $0 \pm 0$ & $42 \pm 42$ & $333 \pm 42$ \\
\hline Taungya & $83 \pm 42$ & $42 \pm 42$ & $42 \pm 42$ & $0 \pm 0$ & $167 \pm 83$ \\
\hline Pioneira/Tardia & $83 \pm 42$ & $0 \pm 0$ & $83 \pm 83$ & $0 \pm 0$ & $167 \pm 110$ \\
\hline Restauração & $167 \pm 110$ & $42 \pm 42$ & $83 \pm 83$ & $0 \pm 0$ & $292 \pm 150$ \\
\hline Fragmento & $292 \pm 83$ & $42 \pm 42$ & $56 \pm 37$ & $42 \pm 42$ & $432 \pm 91$ \\
\hline Revegetação & $133 \pm 36$ & $50 \pm 14$ & $42 \pm 22$ & $8 \pm 8$ & $233 \pm 33$ \\
\hline \multirow[t]{2}{*}{ Média } & $160 \pm 35$ & $49 \pm 14$ & $44 \pm 12$ & $14 \pm 7$ & $267 \pm 36$ \\
\hline & \multicolumn{5}{|c|}{ Quarta amostragem (Mar/01) } \\
\hline Testemunha & $125 \pm 72$ & $0 \pm 0$ & $42 \pm 42$ & $0 \pm 0$ & $167 \pm 110$ \\
\hline Sem.Direta & $167 \pm 83$ & $42 \pm 42$ & $42 \pm 42$ & $42 \pm 42$ & $292 \pm 42$ \\
\hline Taungya & $167 \pm 83$ & $83 \pm 42$ & $0 \pm 0$ & $0 \pm 0$ & $250 \pm 72$ \\
\hline Pioneira/Tardia & $42 \pm 42$ & $83 \pm 83$ & $0 \pm 0$ & $0 \pm 0$ & $125 \pm 72$ \\
\hline Restauração & $125 \pm 125$ & $83 \pm 42$ & $42 \pm 42$ & $0 \pm 0$ & $250 \pm 125$ \\
\hline Fragmento & $458 \pm 273$ & $167 \pm 167$ & $125 \pm 72$ & $42 \pm 42$ & $792 \pm 542$ \\
\hline Revegetação & $125 \pm 38$ & $58 \pm 30$ & $25 \pm 14$ & $8 \pm 8$ & $217 \pm 55$ \\
\hline Média & $181 \pm 18$ & $76 \pm 42$ & $42 \pm 0$ & $14 \pm 14$ & $313 \pm 72$ \\
\hline
\end{tabular}


Tabela 5. Densidades observadas (média \pm erro-padrão) para a ocorrência de subordens de ácaros no LVA, nos diferentes tratamentos e épocas de amostragem.

\begin{tabular}{|c|c|c|c|c|c|}
\hline \multirow[b]{2}{*}{ Tratamento } & \multicolumn{4}{|c|}{ Subordem de Ácaros } & \multirow[b]{2}{*}{ Total } \\
\hline & Oribatida & Mesostigmata & Astigmata & Prostigmata & \\
\hline & \multicolumn{5}{|c|}{ Número de indivíduos $\mathrm{m}^{-2}$} \\
\hline & \multicolumn{5}{|c|}{ Primeira amostragem (Dez/98) } \\
\hline Demais Trat. & $431 \pm 160$ & $361 \pm 155$ & $83 \pm 83$ & $0 \pm 0$ & $875 \pm 229$ \\
\hline Sem.Direta & $458 \pm 105$ & $611 \pm 294$ & $0 \pm 0$ & $0 \pm 0$ & $1.069 \pm 397$ \\
\hline Fragmento & $694 \pm 194$ & $500 \pm 96$ & $56 \pm 56$ & $0 \pm 0$ & $1.250 \pm 48$ \\
\hline Revegetação & $444 \pm 121$ & $486 \pm 224$ & $42 \pm 42$ & $0 \pm 0$ & $972 \pm 309$ \\
\hline \multirow[t]{2}{*}{ Média } & $528 \pm 58$ & $491 \pm 180$ & $46 \pm 24$ & $0 \pm 0$ & $1.065 \pm 191$ \\
\hline & \multicolumn{5}{|c|}{ Segunda amostragem $(\mathrm{Jul} / 99)$} \\
\hline Testemunha & $208 \pm 110$ & $125 \pm 72$ & $0 \pm 0$ & $0 \pm 0$ & $333 \pm 42$ \\
\hline Sem.Direta & $167 \pm 83$ & $125 \pm 72$ & $42 \pm 42$ & $0 \pm 0$ & $333 \pm 150$ \\
\hline Taungya & $167 \pm 167$ & $125 \pm 0$ & $0 \pm 0$ & $0 \pm 0$ & $292 \pm 167$ \\
\hline Pioneira/Tardia & $208 \pm 83$ & $83 \pm 42$ & $0 \pm 0$ & $0 \pm 0$ & $292 \pm 42$ \\
\hline Restauração & $125 \pm 0$ & $167 \pm 102$ & $0 \pm 0$ & $0 \pm 0$ & $292 \pm 110$ \\
\hline Fragmento & $250 \pm 72$ & $250 \pm 125$ & $42 \pm 42$ & $0 \pm 0$ & $542 \pm 110$ \\
\hline Revegetação & $175 \pm 38$ & $125 \pm 14$ & $8 \pm 8$ & $0 \pm 0$ & $308 \pm 51$ \\
\hline \multirow[t]{2}{*}{ Média } & $188 \pm 29$ & $146 \pm 24$ & $14 \pm 14$ & $0 \pm 0$ & $347 \pm 57$ \\
\hline & \multicolumn{5}{|c|}{ Terceira amostragem (Ago/00) } \\
\hline Testemunha & $417 \pm 42$ & $42 \pm 42$ & $0 \pm 0$ & $0 \pm 0$ & $458 \pm 83$ \\
\hline Sem.Direta & $125 \pm 0$ & $0 \pm 0$ & $0 \pm 0$ & $0 \pm 0$ & $125 \pm 0$ \\
\hline Taungya & $42 \pm 42$ & $42 \pm 42$ & $0 \pm 0$ & $0 \pm 0$ & $83 \pm 42$ \\
\hline Pioneira/Tardia & $125 \pm 72$ & $42 \pm 42$ & $0 \pm 0$ & $0 \pm 0$ & $167 \pm 42$ \\
\hline Restauração & $167 \pm 110$ & $42 \pm 42$ & $0 \pm 0$ & $0 \pm 0$ & $208 \pm 83$ \\
\hline Fragmento & $333 \pm 110$ & $125 \pm 72$ & $42 \pm 42$ & $0 \pm 0$ & $500 \pm 125$ \\
\hline Revegetação & $175 \pm 25$ & $33 \pm 17$ & $0 \pm 0$ & $0 \pm 0$ & $208 \pm 8$ \\
\hline \multirow[t]{2}{*}{ Média } & $201 \pm 7$ & $49 \pm 18$ & $7 \pm 7$ & $0 \pm 0$ & $257 \pm 14$ \\
\hline & \multicolumn{5}{|c|}{ Quarta amostragem (Mar/01) } \\
\hline Testemunha & $125 \pm 72$ & $83 \pm 42$ & $0 \pm 0$ & $0 \pm 0$ & $208 \pm 110$ \\
\hline Sem.Direta & $83 \pm 42$ & $0 \pm 0$ & $0 \pm 0$ & $42 \pm 42$ & $125 \pm 72$ \\
\hline Taungya & $42 \pm 42$ & $0 \pm 0$ & $42 \pm 42$ & $0 \pm 0$ & $83 \pm 83$ \\
\hline Pioneira/Tardia & $250 \pm 144$ & $83 \pm 42$ & $0 \pm 0$ & $0 \pm 0$ & $333 \pm 182$ \\
\hline Restauração & $167 \pm 83$ & $83 \pm 83$ & $42 \pm 42$ & $0 \pm 0$ & $292 \pm 150$ \\
\hline Fragmento & $167 \pm 42$ & $83 \pm 42$ & $83 \pm 83$ & $42 \pm 42$ & $375 \pm 72$ \\
\hline Revegetação & $133 \pm 33$ & $50 \pm 14$ & $17 \pm 8$ & $8 \pm 8$ & $208 \pm 33$ \\
\hline Média & $139 \pm 35$ & $56 \pm 14$ & $28 \pm 18$ & $14 \pm 7$ & $236 \pm 18$ \\
\hline
\end{tabular}


Durante a etapa de identificação, foi observado que algumas amostras não continham indivíduos da acarofauna para identificação. Nos três solos, notou-se que em todas as amostragens, a quantidade de amostras sem ácaros foi menor no Fragmento em relação à Revegetação (Figura 9), mas somente no PVA e LVA, a quantidade de amostras sem ácaros no Fragmento foi menor que em todos os demais tratamentos e em todas as amostragens.

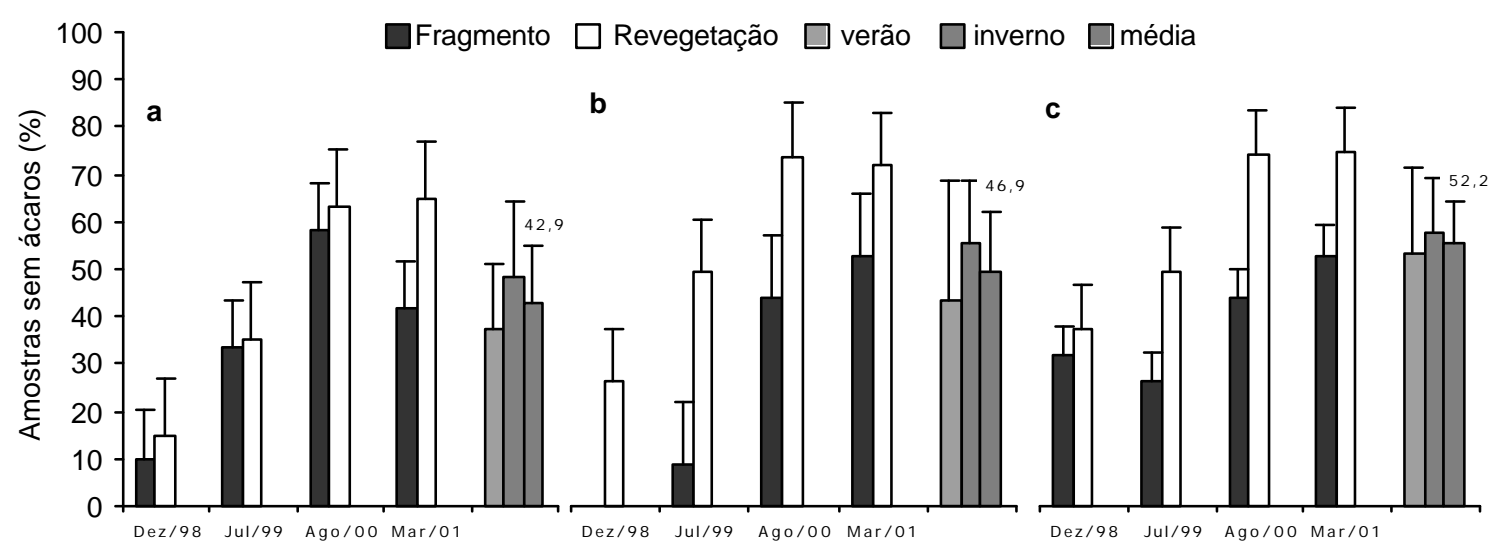

Figura 9 - Quantidade de amostras sem ácaros (média + erro-padrão) nos tratamentos Fragmento e Revegetação, nas diferentes épocas de amostragem, no: a) NV, b) PVA e c) LVA.

A menor densidade de ácaros, exceto nas duas primeiras amostragens no NV, e a maior quantidade de amostras sem ácaros, nos ambientes revegetados, têm como causas plausíveis o menor teor de matéria orgânica e de nutrientes e a alteração das propriedades físicas do solo quando comparado ao ambiente natural (Tabela 6). Além de apresentar-se mais ácido e menos poroso, o solo no Revegetação na camada $0-5 \mathrm{~cm}$, profundidade onde a maioria das espécies vivem (Larink, 1997), e nas camadas 5-10 e 10-20cm, possuía teores de P-resina, $\mathrm{Ca}$ e $\mathrm{Mg}$ e $\mathrm{CTC}_{\mathrm{e}}$ sempre menores que do Fragmento (Tabela 6). 
Tabela 6. Atributos físicos e químicos dos solos nos tratamentos Revegetação e Fragmento (Nogueira Junior, 2000) no NV, PVA e LVA.

\begin{tabular}{|c|c|c|c|c|c|c|c|c|c|c|c|c|c|c|}
\hline \multirow[b]{2}{*}{ Tratamento } & \multicolumn{3}{|c|}{ Textura } & \multicolumn{2}{|c|}{ Densidade } & \multicolumn{3}{|c|}{$\mathrm{pH}$} & \multirow{2}{*}{ P-resina } & \multirow[b]{2}{*}{$\mathrm{Ca}$} & \multirow[b]{2}{*}{$\mathrm{Mg}$} & \multirow[b]{2}{*}{$\mathrm{K}$} & \multirow[b]{2}{*}{$\mathrm{Al}$} & \multirow[b]{2}{*}{$\mathrm{CTC}_{\mathrm{e}}$} \\
\hline & Argila & Silte & Areia & Solo & Part. & Poros. & $\mathrm{CaCl}_{2}$ & MO & & & & & & \\
\hline & & $-\mathrm{g} \mathrm{kg}^{-1}$ & & $---\mathrm{g}$ & $\mathrm{dm}^{-3}$ & $\%$ & & $\mathrm{~g} \mathrm{dm}^{-3}$ & $\mathrm{mg} \mathrm{dm}^{-3}$ & & & $\mathrm{mmo}$ & $\mathrm{dm}^{3}$ & \\
\hline \multicolumn{15}{|c|}{ NITOSSOLO VERMELHO } \\
\hline \multicolumn{15}{|c|}{$0-5 \mathrm{~cm}$} \\
\hline Revegetação & 530 & 167 & 300 & 2,7 & 0,99 & 63 & 5,8 & 51 & 40 & 84 & 26 & 4,7 & 0,1 & 114,8 \\
\hline Fragmento & 337 & 246 & 417 & 2,6 & 0,91 & 65 & 6,7 & 107 & 98 & 317 & 43 & 4,6 & 0,4 & 365 \\
\hline \multicolumn{15}{|c|}{$5-10 \mathrm{~cm}$} \\
\hline Revegetação & 530 & 167 & 300 & 2,7 & 0,99 & 63 & 5,7 & 44 & 22 & 59 & 22 & 4,8 & 0,4 & 86,2 \\
\hline Fragmento & 337 & 246 & 417 & 2,6 & 0,91 & 65 & 6,3 & 84 & 106 & 274 & 44 & 4,1 & 0,2 & 322,3 \\
\hline \multicolumn{15}{|c|}{$10-20 \mathrm{~cm}$} \\
\hline Revegetação & 670 & 120 & 210 & 2,8 & 0,99 & 65 & 5,7 & 37 & 16 & 77 & 18 & 3,6 & 0,5 & 99,1 \\
\hline Fragmento & 427 & 223 & 350 & 2,6 & 0,91 & 65 & 5,7 & 73 & 73 & 236 & 44 & 3,4 & 0,5 & 283,9 \\
\hline \multicolumn{15}{|c|}{ ARGISSOLO VERMELHO-AMARELO } \\
\hline \multicolumn{15}{|c|}{$0-5 \mathrm{~cm}$} \\
\hline Revegetação & 80 & 0 & 920 & 2,5 & 1,45 & 42 & 5,6 & 16 & 27 & 18 & 12 & 2,3 & 0,1 & 32,4 \\
\hline Fragmento & 60 & 20 & 920 & 2,6 & 1,24 & 53 & 5,8 & 44 & 33 & 83 & 14 & 8,7 & 0,7 & 106,4 \\
\hline \multicolumn{15}{|c|}{$5-10 \mathrm{~cm}$} \\
\hline Revegetação & 80 & 0 & 920 & 2,5 & 1,45 & 42 & 5,1 & 14 & 19 & 14 & 8,4 & 1,7 & 0,6 & 24,7 \\
\hline Fragmento & 60 & 20 & 920 & 2,6 & 1,24 & 53 & 5,4 & 27 & 25 & 52 & 10 & 2,4 & 0,6 & 65 \\
\hline \multicolumn{15}{|c|}{$10-20 \mathrm{~cm}$} \\
\hline Revegetação & 100 & 0 & 899 & 2,5 & 1,45 & 42 & 4,6 & 11 & 12 & 12 & 5,8 & 1,3 & 1,6 & 20,7 \\
\hline Fragmento & 47 & 20 & 933 & 2,6 & 1,24 & 53 & 5,1 & 18 & 18 & 32 & 7,8 & 1,7 & 0,9 & 42,4 \\
\hline \multicolumn{15}{|c|}{ LATOSSOLO VERMELHO-AMARELO } \\
\hline \multicolumn{15}{|c|}{$0-5 \mathrm{~cm}$} \\
\hline Revegetação & 60 & 20 & 920 & 2,6 & 1,45 & 44 & 4,8 & 17 & 14 & 14 & 5,2 & 3,1 & 0,6 & 22,9 \\
\hline Fragmento & 196 & 149 & 655 & 2,6 & 1,3 & 50 & 6,1 & 86 & 88 & 218 & 42 & 5,4 & 0,4 & 265,8 \\
\hline \multicolumn{15}{|c|}{$5-10 \mathrm{~cm}$} \\
\hline Revegetação & 60 & 20 & 920 & 2,6 & 1,45 & 44 & 4,6 & 13 & 13 & 13 & 4,4 & 1,9 & 1,2 & 20,5 \\
\hline Fragmento & 196 & 149 & 655 & 2,6 & 1,3 & 50 & 5,7 & 40 & 72 & 125 & 34 & 3,8 & 0,3 & 163,1 \\
\hline \multicolumn{15}{|c|}{$10-20 \mathrm{~cm}$} \\
\hline Revegetação & 47 & 20 & 933 & 2,6 & 1,45 & 44 & 4,4 & 7,6 & 12 & 12 & 2,6 & 1,1 & 1,8 & 17,5 \\
\hline Fragmento & 224 & 176 & 600 & 2,6 & 1,3 & 50 & 5,5 & 32 & 65 & 106 & 38 & 4,1 & 0,4 & 148,5 \\
\hline
\end{tabular}


A exposição dos ácaros à temperaturas do solo mais elevadas e à maiores flutuações também apresentou-se como uma das causas da variação da densidade e presença de ácaros no solo. No Fragmento, ambiente com temperatura do solo inferior ao Revegetação, em todas as amostragens e solos (Figura 10), as diferenças entre temperaturas do verão e inverno foram de 6,$0 ; 8,5$ e $6,5^{\circ} \mathrm{C}$ no $\mathrm{NV}$, PVA e LVA, respectivamente. No Revegetação, a oscilação de temperatura foi maior, chegando a $14^{\circ} \mathrm{C}$ no LVA. A umidade do solo, fator que também pode afetar as populações de fauna edáfica, apesar de ser mais elevada no Fragmento apenas no LVA, oscilou mais entre as épocas amostrais dentro do Revegetação no PVA e LVA, e foi equivalente ao Fragmento no NV. Para Gonçalves et al. (2000), a redução das perdas de água por evaporação, assim como das amplitudes de variação térmica e hídrica do solo ao longo das estações climáticas do ano são fatores que fazem com que os organismos do solo encontrem um microambiente mais adequado para sua sobrevivência e multiplicação, ocorrendo em maior variedade e abundância.

No mesmo período, Nogueira Junior (2000) encontrou no Fragmento os maiores teores de $\mathrm{C}$ da biomassa microbiana e as maiores taxas de mineralização de $\mathrm{N}$, indicando que, em ambientes pouco ou não perturbados, são encontradas as condições mais favoráveis à manutenção da vida microbiana do solo, correlatamente, à proliferação e sobrevivência da acarofauna.

Em dez/98 e jul/99 no NV, a maior densidade de ácaros encontrada no Revegetação foi decisivamente influenciada pela elevada quantidade de oribatídeos observada neste ambiente. A densidade de ácaros das demais subordens foi muito baixa em relação aos da Oribatida, e suas participações não interferiram na densidade total de ácaros. 
Revegetação

Fragmento
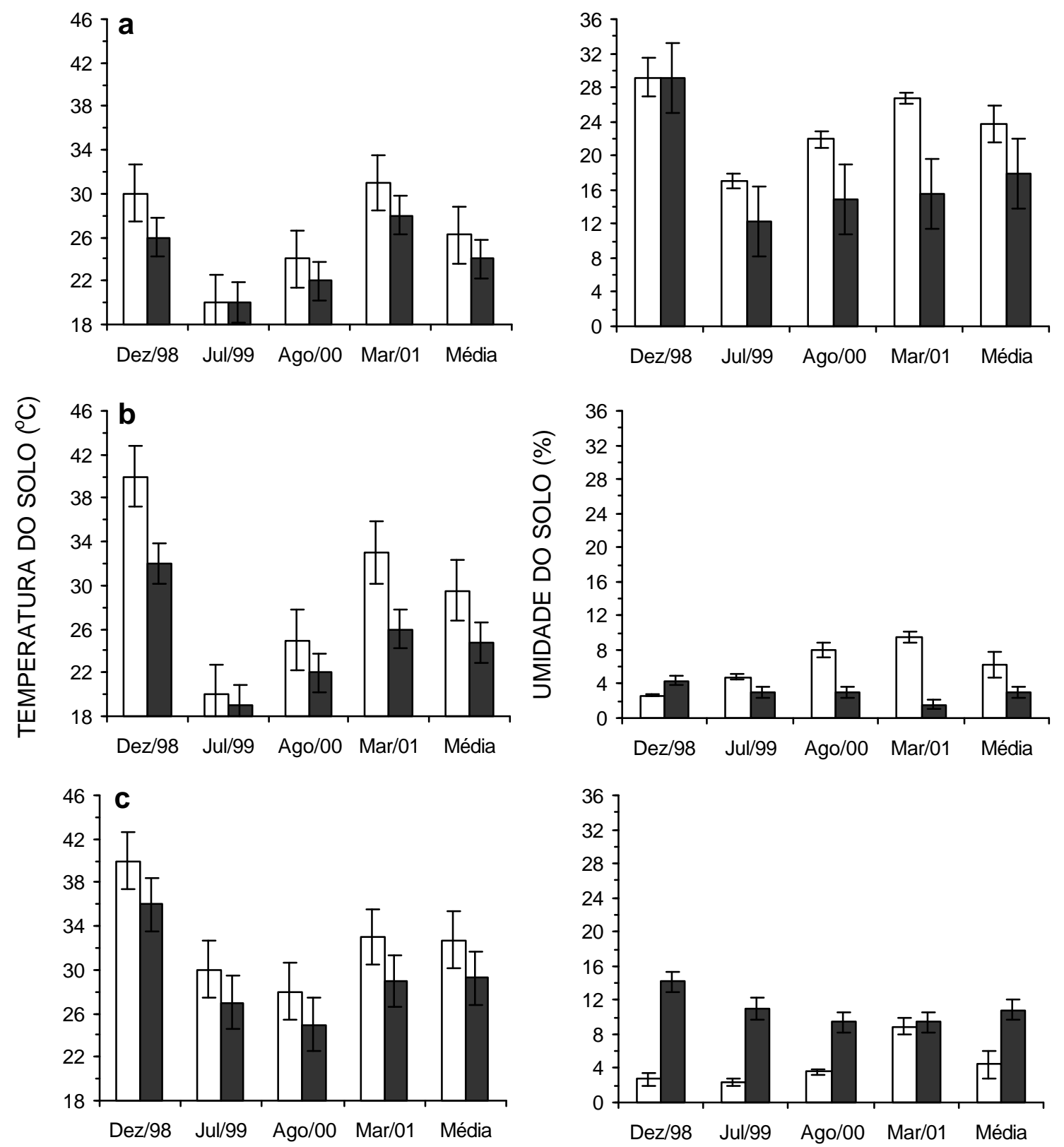

Figura 10 - Temperatura do solo (média \pm erro-padrão) a $5 \mathrm{~cm}$ de profundidade medida às 14:00 hs, com 3 repetições, e umidade do solo (média \pm erro-padrão) $(0-15 \mathrm{~cm}) \mathrm{com}$ 3 repetições, realizadas nas diferentes épocas de amostragens no Revegetação e Fragmento no: a) NV, b) PVA e c) LVA. 
O Sem.Direta e o Testemunha se destacaram como os tratamentos com a segunda maior densidade de ácaros em praticamente todas as épocas amostrais (Tabelas 3, 4 e 5). Como consequiência, a densidade média geral de todas as amostragens, nos três solos, foi superior no Fragmento, seguido pelos tratamentos Testemunha ou Sem.Direta (Figura 11). Essas observações podem ser explicadas pelas condições de cada tratamento. O Sem.Direta (implantado em mar/97, dez meses antes dos demais tratamentos), além de não ter sofrido intenso preparo do solo na época do plantio, apresentava maior desenvolvimento de cobertura vegetal em relação aos demais tratamentos. No Testemunha, o solo não foi preparado, permanecendo protegido por grande quantidade de vegetação herbácea, principalmente gramíneas, que chegavam a atingir $3 \mathrm{~m}$ de altura. Isso diminuiu a insolação direta, a evaporação superficial de água e a quebra de capilaridade, favorecendo a população de acarofauna. Em ago/00, os efeitos da diferença de idade dos plantios e do revolvimento do solo no crescimento das plantas entre os tratamentos revegetados já não era tão evidente, e outros tratamentos (como Taungya, Pioneira/Tardia e Restauração) também apresentaram densidades próximas ou superiores ao Sem.Direta e Testemunha.

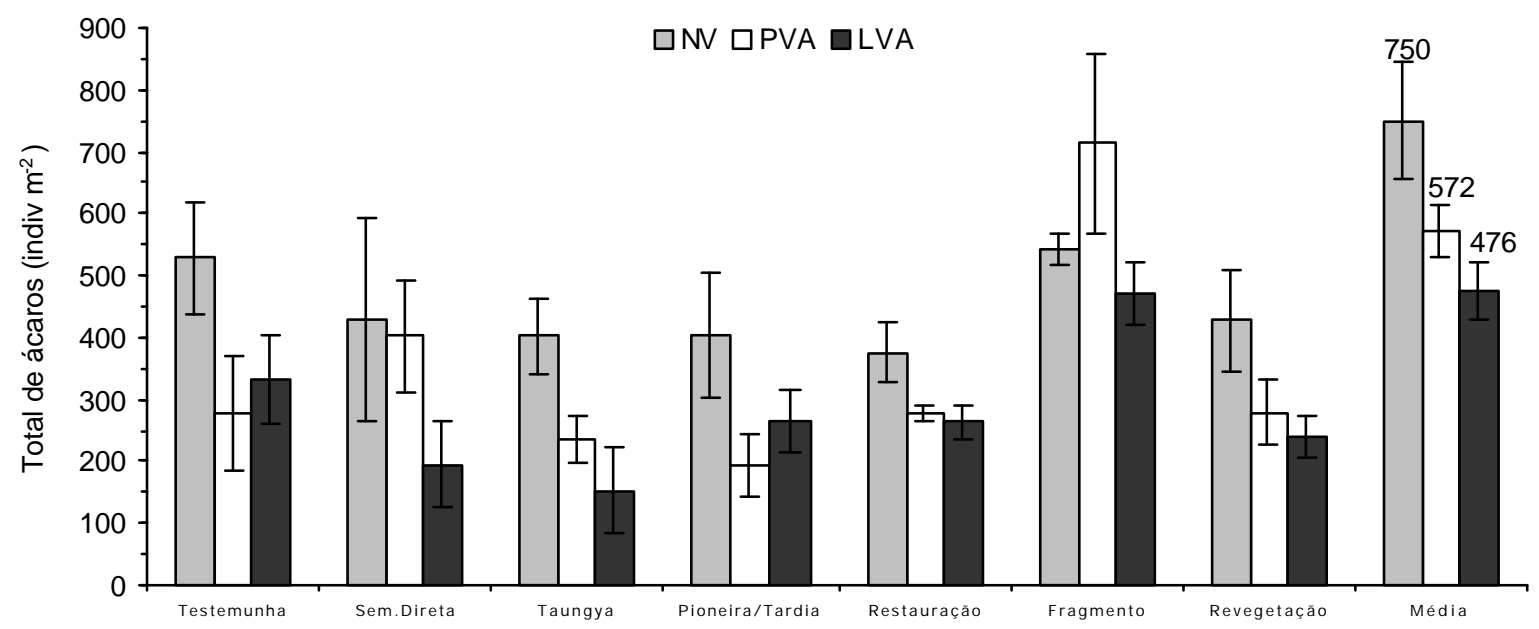

Figura 11 - Densidade total (média \pm erro-padrão) de ácaros em cada tratamento na média de todas as amostragens, e densidade média (média \pm erro-padrão) de cada solo. 
Na Figura 12, encontram-se os dendogramas obtidos pela análise de Cluster, onde os números no eixo vertical representam a distância Euclidiana reescalada de 0 a 1 e no eixo horizontal, os tratamentos que geraram os grupos. Verificou-se que a análise ratificou a classificação dos melhores tratamentos nos três solos. Formou, no NV, dois grupos distintos, com maior similaridade (quase 90\%) no composto pelo Fragmento e pelo Testemunha. Este grupo distanciou-se do outro em mais de 70\%. No PVA, a análise isolou o Fragmento, distante 50\% do Sem.Direta e 70\% dos demais tratamentos; estes, possuíam as maiores similaridades. No LVA, o Fragmento também foi separado dos demais tratamentos, explicável pelas suas melhores condições físicas e químicas; entre o Fragmento e o grupo formado pelos tratamentos Sem.Direta e o Taungya, de menores densidades e maior similaridade, a distância chegou a 70\% (Figura 12).

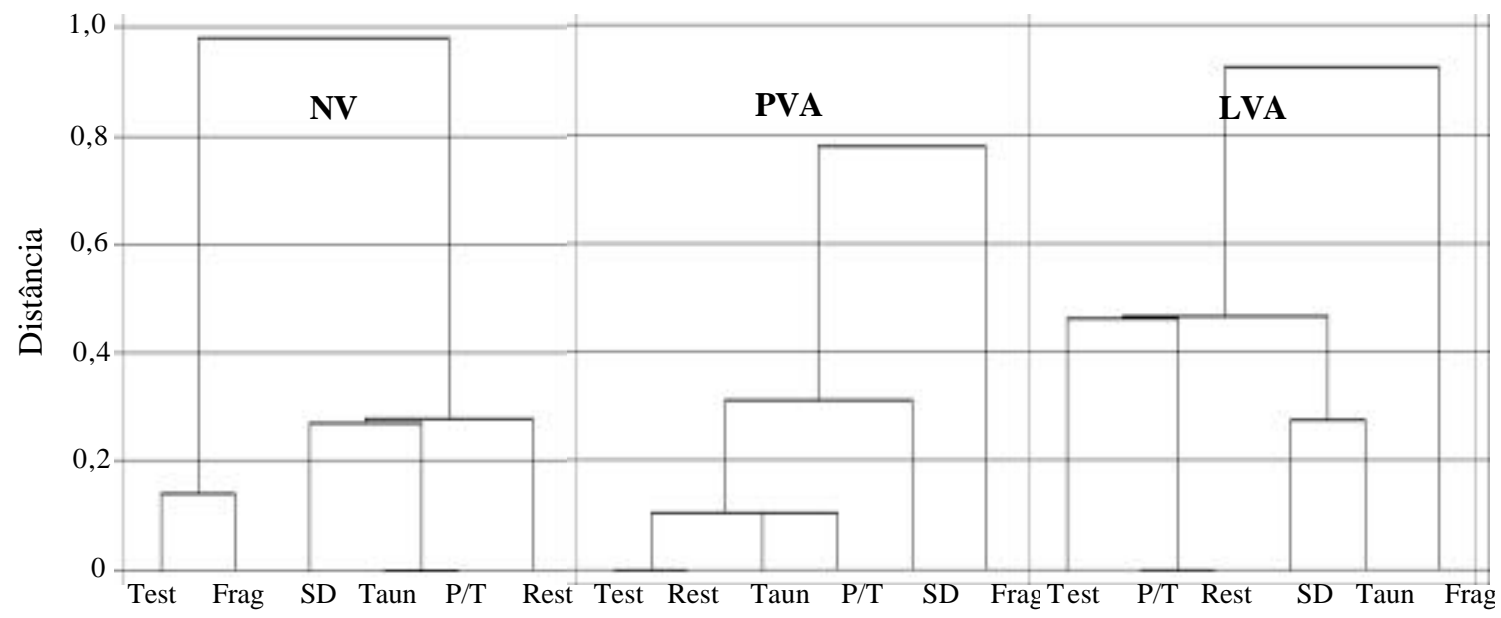

Figura 12 - Dendogramas obtidos pela análise de Cluster para densidade de ácaros na média de todas as amostragens, discriminando os tratamentos ${ }^{3}$ para os três solos, e utilizandose a Distância Euclidiana e a Ligação Simples.

${ }^{3}$ Abreviações dos tratamentos: Test $=$ Testemunha; $\mathrm{SD}=$ Sem.Direta; Taun = Taungya; $\mathrm{P} / \mathrm{T}=$ Pioneira $/$ Tardia; Rest $=$ restauração; Frag $=$ Fragmento

Na média geral de todas as amostragens, a maior densidade de ácaros e a menor quantidade de amostras sem ácaros (43, 47 e 52\% para NV, PVA e LVA, respectivamente) foi encontrada no NV (Figuras 9 e 11), solo com maior teor de matéria orgânica, mais fértil e menos ácido (Tabela 6), com menor temperatura média e maior umidade do solo (Figura 13). Essa maior densidade de ácaros justifica-se porque o 
número e as espécies de organismos que populam um solo são determinados, em grande parte, pela alimentação disponível e, quanto maior o teor de matéria orgânica e melhor sua qualidade, tanto mais organismos haverá (Primavesi, 1990). Associado à matéria orgânica do solo é encontrada em grande quantidade os fungos, alimento preferido de muitos ácaros (Larink, 1997). Sautter \& Trevisan (1994), estudando a população de Oribatei (Acari: Cryptostigmata) e Collembola (Insecta), em três solos plantados com Pinus taeda, concluíram que estes organismos foram mais numerosos no solo sob maior camada de serapilheira.

A textura e estrutura do solo também influenciam a densidade de ácaros à medida que eles precisam de espaço poroso (macroporos contínuos), por isso sendo encontrados em maior quantidade em solos mais arenosos (Larink, 1997). No entanto, no $\mathrm{NV}$, solo mais argiloso, foram encontrados em maior densidade devido à boa estrutura deste solo (óxidos) e aos maiores teores de matéria orgânica e nutrientes minerais. No NV, tendo como referência o tratamentos Sem.Direta, Engel \& Parrota (2001), na mesma área e época experimental, observaram maiores facilidades no estabelecimento (densidade) e crescimento da maioria das plantas no solo NV (Tabela 7). Igualmente, Nogueira Junior (2000) encontrou maiores teores de biomassa microbiana neste solo. Essas constatações corroboram as melhores condições de vida para a população de ácaros neste solo.
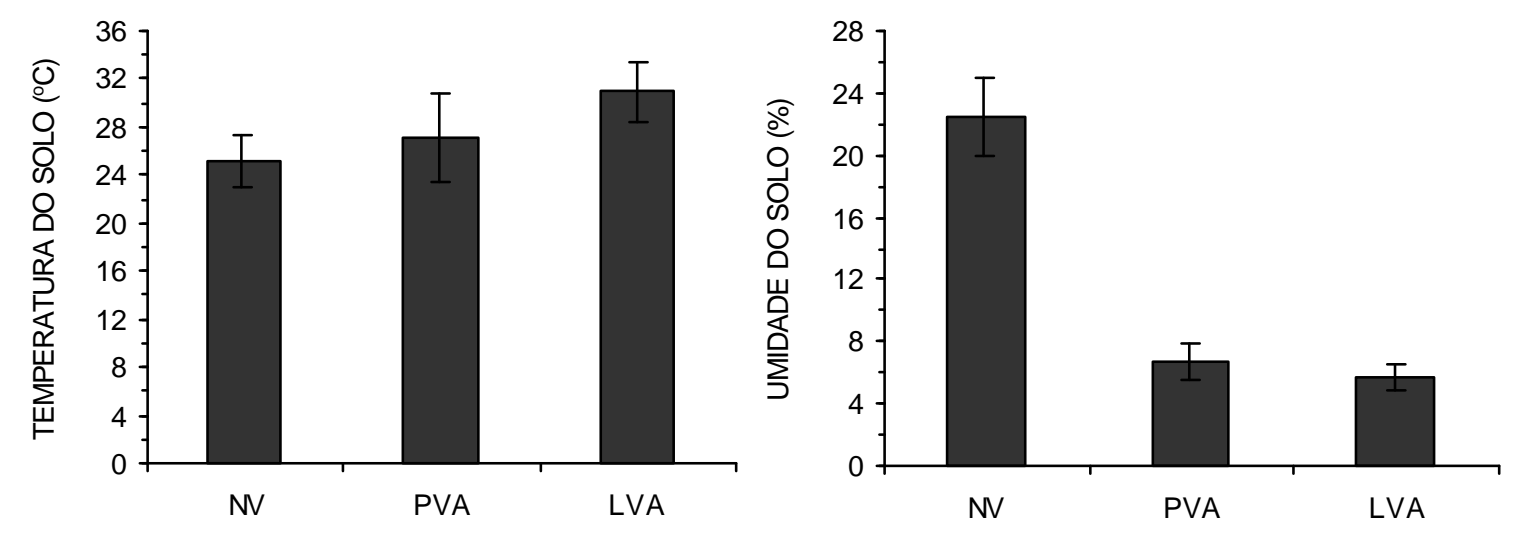

Figura 13 - Temperatura (média \pm erro-padrão) e umidade do solo (média \pm erro-padrão), média de todas as amostragens, nos diferentes solos. 
Tabela 7. Estabelecimento ${ }^{4}$ (45 dias pós-semeadura) e crescimento das plantas (dois anos póssemeadura) no Sem.Direta no NV, PVA e LVA. Dados obtidos na mesma área e época experimental por Engel \& Parrota (2001).

\begin{tabular}{lccc}
\hline Espécie & NV & PVA & LVA \\
\hline & Densidade de Plantas $\left(\mathbf{n}^{-\mathbf{h a}} \mathbf{- 1}^{\mathbf{1}}\right)$ aos 45 & dias pós-semeadura \\
Chorisia speciosa & $752 \pm 171$ & $344 \pm 110$ & $308 \pm 97$ \\
Croton floribundus & 0 & 0 & 0 \\
Enterolobium contorstisiliquum & $924 \pm 153$ & $1209 \pm 49$ & $1009 \pm 127$ \\
Mimosa scabrella & $268 \pm 135$ & $39 \pm 39$ & 0 \\
Schizolobium parahyba & $564 \pm 150$ & $540 \pm 42$ & $611 \pm 256$ \\
Todas as espécies & $2508 \pm 233$ & $2132 \pm 200$ & $1928 \pm 330$ \\
& & Altura (m) & \\
Chorisia speciosa & $0,4 \pm 0,3$ & $0,1 \pm 0,1$ & 0 \\
Croton floribundus & $1,0 \pm 1,0$ & 0 & $0,5 \pm 0,5$ \\
Enterolobium contorstisiliquum & $1,6 \pm 0,2$ & $2,2 \pm 0,2$ & $0,8 \pm 0,1$ \\
Mimosa scabrella & $1,3 \pm 1,0$ & 0 & 0 \\
Schizolobium parahyba & $2,0 \pm 0,4$ & $1,4 \pm 0,02$ & $1,8 \pm 0,4$ \\
& & Diâmetro do colo (cm) & \\
Chorisia speciosa & $1,2 \pm 0,8$ & $0,4 \pm 0,4$ & 0 \\
Croton floribundus & $1,4 \pm 1,4$ & 0 & $0,1 \pm 0,1$ \\
Enterolobium contorstisiliquum & $4,1 \pm 0,4$ & $6,5 \pm 1,2$ & $1,8 \pm 0,3$ \\
Mimosa scabrella & $1,9 \pm 1,0$ & 0 & 0 \\
Schizolobium parahyba & $4,5 \pm 1,2$ & $4,8 \pm 0,6$ & $4,6 \pm 0,7$ \\
\hline${ }^{4}$ Valores médios das repetições por parcela em cada área \pm desvio padrão (n=3); & & \\
& & &
\end{tabular}

A densidade de oribatídeos, mesostigmatas e prostigmatas teve comportamento geral semelhante à densidade total de ácaros (Tabelas 3, 4 e 5 ). A grande densidade de oribatídeos ocorrida no Revegetação do $\mathrm{NV}$, nos primeiros meses após o reflorestamento, se deve às melhores condições físicas e químicas deste solo, além de sua maior facilidade de adaptação morfológica, fisiológica e ecológica, comparado aos astigmatas, prostigmatas e mesostigmatas (Krantz, 1978; Guerra et al., 1982). Em todos os solos, o erro-padrão da densidade de oribatídeos foi maior que as demais subordens de ácaros, na maioria das amostragens, o que pode ser explicado por sua distribuição agregada (Oliveira, 1999), portanto, com maior variação entre pontos de amostragem. Entre todas as subordens de ácaros, os oribatídeos foram encontrados em maior densidade, nos três solos (Figura 14). Isso confirma esta subordem de ácaros como uma das mais representativas de toda a fauna edáfica, como também constatado por Krantz 
(1978) e Oliveira (1999). Mesmo variando conforme o solo, a participação dos oribatídeos no total de ácaros foi sempre superior a 50\%, chegando a $56 \%$ no NV (Figura 14). Semelhantemente, Paschoal et al. (1996) citam que, num solo não perturbado, ocorrem cerca de 200.000 ácaros $\mathrm{m}^{-2}, 70 \%$ dos quais oribatídeos.

Os mesostigmatas, mesmo sendo cosmopolitas (Mineiro, 2000), têm a sua densidade correlacionada com o conteúdo de matéria orgânica do solo (Poggiani et al., 1996), o que explica as maiores densidades observadas no Fragmento, nos três solos estudados. A exceção aconteceu na amostragem de ago/00 no PVA, mas com a maior densidade observada no Testemunha e Sem.Direta (Tabelas 3, 4 e 5). Mesmo não sendo tão numerosos como os oribatídeos (Coleman \& Crossley, 1996), os mesostigmatas foram o segundo grupo mais observado em todos os solos (Figura 14).

Apesar de serem amplamente distribuídos geograficamente, de ocorrência em todo ecossistema terrestre (Krantz, 1978), a densidade de prostigmatas foi influenciada positivamente pelas melhores condições físicas e químicas do Fragmento, nos três solos, e foram os menos encontrados, participando com o máximo de $1,7 \%$, no NV (Figura 14). Diferentemente dos prostigmatas, os astigmatas sofreram influência positiva do Fragmento em todas as amostragens, apenas no LVA (Tabela 5). No NV e PVA, os astigmatas foram encontrados em maiores quantidades nos modelos revegetados nas duas primeiras amostragens, com maiores densidades no Sem.Direta e no Testemunha (Tabelas 3 e 4). Os astigmatas podem ser encontrados abundantemente em alguns agroecossistemas após a colheita ou depois da aplicação de adubo, mas também são favorecidos pelo ambiente rico em matéria orgânica (Coleman \& Crossley, 1996) e são muito dependentes de boas condições ambientais, o que pode explicar a maior densidade destes ácaros no Revegetação do NV e PVA logo após a instalação do experimento (dez/98 e jul/99). A população desses ácaros, que varia conforme o tipo de solo e a quantidade de serapilheira, e, geralmente, compreende de 2 a 3\% dos microartrópodos em florestas (Krantz, 1978), contribuiu com 5\% (LVA) a 8,5\% (NV) do total de ácaros. Tanto astigmatas como prostigmatas aumentaram sua participação no total de ácaros conforme as melhorias nas características químicas e físicas do solo (Figura 14 e Tabela 6). 


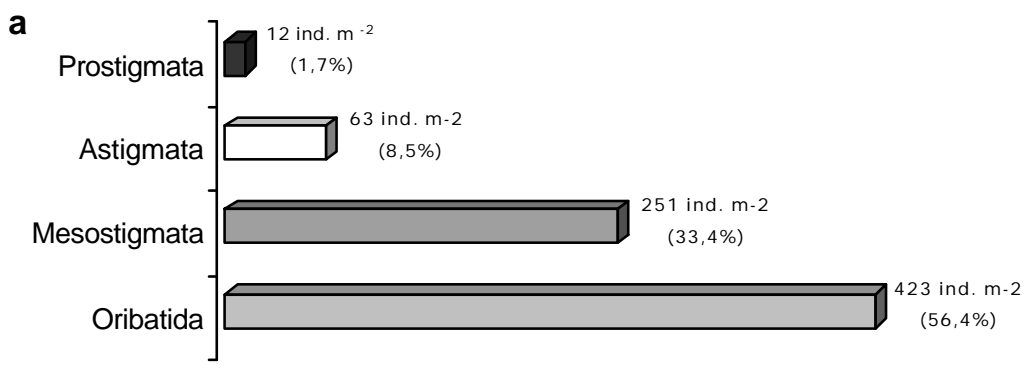

b

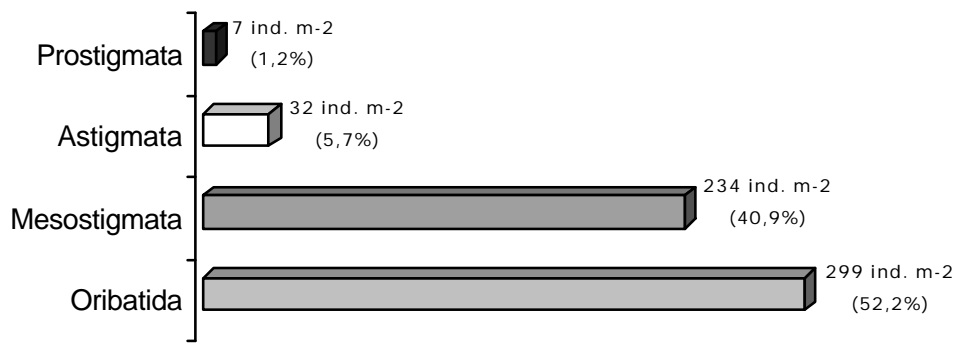

C

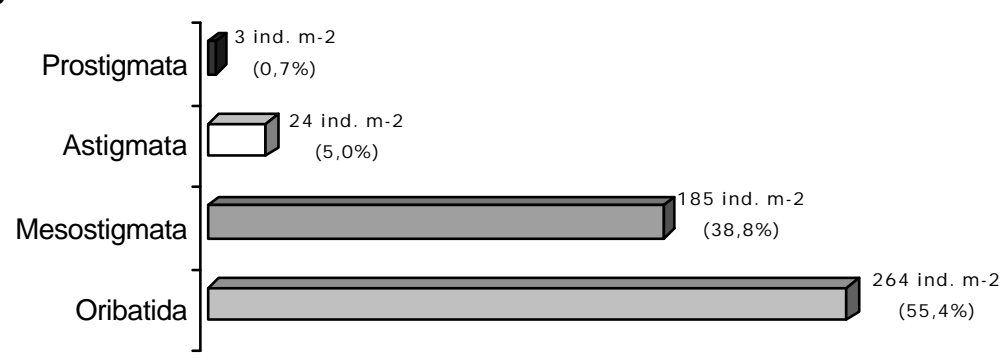

Figura 14 - Participação de cada subordem de ácaro na média das amostragens nos solos a) NV, b) PVA e c) LVA

Nas amostragens de verão, a densidade média de cada subordem e o total de ácaros foram maiores que às de inverno, em todos os solos, perfazendo 69, 68 e $68 \%$ do total de ácaros observados no NV, PVA e LVA, respectivamente. Esses valores são semelhantes ou muito próximos da média de todos os solos (Figura 15), indicando que o efeito da sazonalidade na densidade de ácaros é pouco influenciado pelo tipo de solo. Como estes, os resultados encontrados por Coleman \& Crossley (1996) indicaram que a densidade de oribatídeos, e de outros ácaros, apresenta picos de atividade no início da primavera, continuam no verão, e chegam até o meio do outono. Krantz (1978) encontrou duas vezes mais ácaros no verão que no inverno, no Tenesse. 


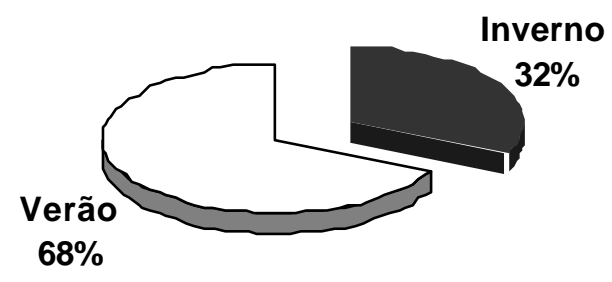

Figura 15 - Distribuição sazonal do total de ácaros, média de todos os solos.

A influência do clima na densidade de ácaros se dá pelo aumento da temperatura do solo e da umidade do solo presentes na época chuvosa $\left(26,3 \%\right.$ e $28,8^{\circ} \mathrm{C}$, $5,8 \%$ e $32,8{ }^{\circ} \mathrm{C}, 7,9 \%$ e $34,5{ }^{\circ} \mathrm{C}$, para $\mathrm{NV}$, PVA e LVA, respectivamente), sempre superiores às encontradas na estação seca (Figura 16). Na estação úmida, a quantidade de amostras sem ácaros foi inversamente proporcional a densidade de ácaros, ou seja, no verão a quantidade de amostras sem ácaros foi menor que no inverno. Em parte, isto é explicado pela migração vertical entre as camadas de solo durante o inverno e períodos secos (Larink, 1997). Portanto, além da influência sobre a densidade da acarofauna, o clima mais quente e úmido também favoreceu a presença desses ácaros na camada superficial do solo. 


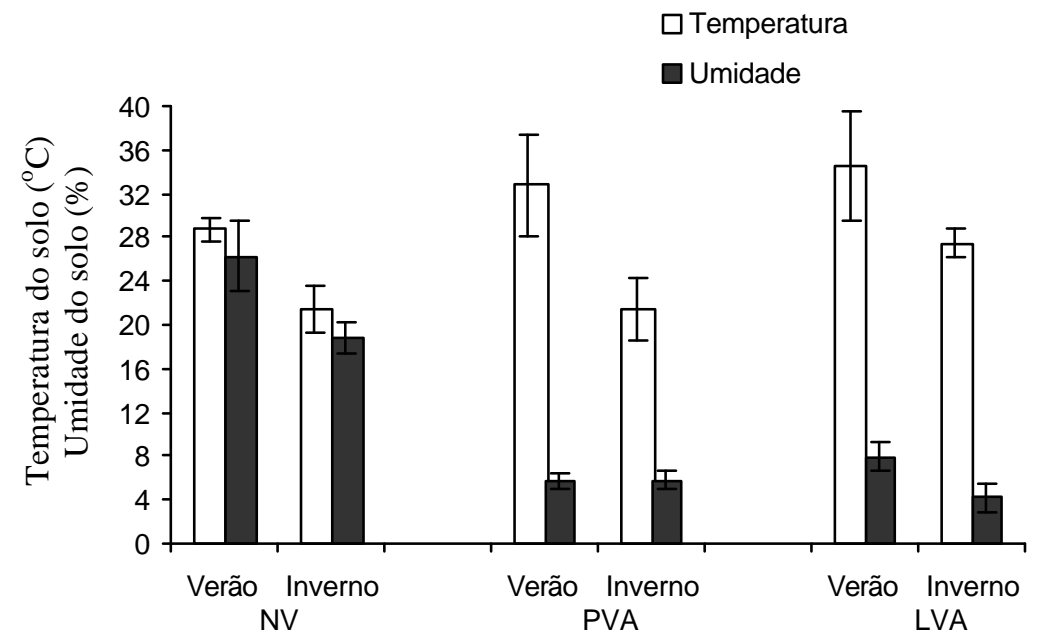

Figura 16 - Temperatura do solo (média \pm erro-padrão) a $5 \mathrm{~cm}$ de profundidade e umidade do solo (média \pm erro-padrão) $(0-15 \mathrm{~cm})$ nas diferentes épocas de amostragens, no NV, PVA e LVA.

\subsection{Macrofauna edáfica}

A densidade de indivíduos pertencentes à macrofauna edáfica foi influenciada pelos tratamentos apenas em dez/98, no NV. Em todas as demais amostragens e solos, aceitou-se a hipótese de nulidade (5\% de probabilidade) do teste de Friedman. Portanto, pode-se afirmar que os tratamentos utilizados diferem ente si quanto à densidade desses organismos no solo, apenas na primeira amostragem no NV (Tabela 8); nesta época, a densidade de macroinvertebrados foi maior no "Demais Trat." (Tabela 9), tratamento com grande quantidade de formigas, representando mais da metade do total de macrofauna.

Tabela 8. Valores obtidos pelo Teste de Friedman para a densidade de macrofauna em cada época de amostragem.

\begin{tabular}{lcccc}
\hline Solo & Dez/98 & Jul/99 & Ago/00 & Mar/01 \\
\hline NV & $6,00^{* *}$ & $9,69^{*}$ & 7,65 & 2,05 \\
PVA & 2,67 & $9,27^{*}$ & 3,83 & 7,96 \\
LVA & $5,64^{*}$ & $10,82^{*}$ & $9,31^{*}$ & 4,10 \\
\hline ** Significativo pelo teste de Friedman, a 5\% de probabilidade. ${ }^{*}$ Significativo pelo teste de Friedman a 10\% de probabilidade
\end{tabular}


Mesmo sendo considerados estatisticamente iguais a 5\% de probabilidade de erro, os tratamentos Sem.Direta e Testemunha (NV e PVA) e Fragmento (LVA) podem ser destacados dos demais, pois possuíam a maior ou elevadas densidade de macrofauna em várias amostragens. Em termos numéricos também, o total de macrofauna no Revegetação foi superior ao Fragmento em todas as amostragens do NV e PVA, exceto em jul/99 no NV, onde a alta densidade de formigas observada no Fragmento pode ter sido responsável pela maior densidade total de macrofauna (Tabelas 9 e 10). No LVA, o total de macrofauna no Fragmento foi superior ao Revegetação em todas as amostragens (Tabela 11).

No NV e PVA, as mudanças ocorridas no ambiente provocaram reações diferentes às observadas para a mesofauna. A redução do teor de matéria orgânica e de nutrientes (Tabela 6), a menor atividade microbiana (Nogueira Junior, 2000), e as maiores temperaturas do solo sob Revegetação (Figura 10), não implicaram em menores densidades de macroinvertebrados. Ao contrário, podem ter contribuído para a diminuição da população de alguns grupos de fauna, aumentando a densidade de outros grupos com rápida taxa de proliferação e dispersão, como besouros, formigas, minhocas e cupins. A manutenção da população da macrofauna no Revegetação também foi favorecida pela maior umidade do solo e maior quantidade de argila encontrada neste ambiente.

No LVA, as características físicas e químicas do ambiente alterado implicaram em prejuízos à proliferação e manutenção das populações dos grupos de macrofauna. Além do Fragmento possuir menor oscilações de umidade e temperatura do solo entre as estações do ano e maior teor de argila, as diferenças de matéria orgânica e de nutrientes entre o Fragmento e o Revegetação foram as mais acentuadas entre todos os solos. 
Tabela 9. Densidades observadas (média \pm erro-padrão) para a ocorrência de grupos de macrofauna no NV, nos diferentes tratamentos e épocas de amostragem.

\begin{tabular}{|c|c|c|c|c|c|c|c|c|}
\hline \multirow[b]{2}{*}{ Tratamento } & \multicolumn{7}{|c|}{ Grupo de Macrofauna } & \multirow[b]{2}{*}{ Total } \\
\hline & Formicidae & Coleoptera & Isoptera & Oligochaeta & Diplopoda & Chilopoda & Outros & \\
\hline & \multicolumn{8}{|c|}{ Número de indivíduos $\mathrm{m}^{2}$} \\
\hline & \multicolumn{8}{|c|}{ Primeira Amostragem (Dez/98) } \\
\hline Demais Trat. & $245 \pm 70$ & $47 \pm 8$ & $23 \pm 6$ & $78 \pm 12$ & $6 \pm 6$ & $0 \pm 0$ & $34 \pm 11$ & $433 \pm 70$ \\
\hline Sem.Direta & $70 \pm 21$ & $28 \pm 6$ & $7 \pm 5$ & $23 \pm 6$ & $51 \pm 11$ & $6 \pm 6$ & $36 \pm 19$ & $222 \pm 46$ \\
\hline Fragmento & $30 \pm 13$ & $58 \pm 8$ & $0 \pm 0$ & $22 \pm 5$ & $36 \pm 11$ & $17 \pm 9$ & $47 \pm 26$ & $209 \pm 46$ \\
\hline Revegetação & $159 \pm 44$ & $38 \pm 4$ & $15 \pm 3$ & $51 \pm 8$ & $29 \pm 5$ & $3 \pm 3$ & $35 \pm 6$ & $328 \pm 52$ \\
\hline \multirow[t]{2}{*}{ Média } & $115 \pm 33$ & $44 \pm 6$ & $10 \pm 2$ & $41 \pm 6$ & $31 \pm 6$ & $8 \pm 5$ & $39 \pm 11$ & $288 \pm 48$ \\
\hline & \multicolumn{8}{|c|}{ Segunda Amostragem (Jul/99) } \\
\hline Testemunha & $23 \pm 23$ & $53 \pm 20$ & $303 \pm 177$ & $106 \pm 95$ & $45 \pm 35$ & $23 \pm 23$ & $30 \pm 15$ & $583 \pm 181$ \\
\hline Sem.Direta & $235 \pm 131$ & $53 \pm 33$ & $182 \pm 182$ & $0 \pm 0$ & $23 \pm 13$ & $18 \pm 14$ & $121 \pm 67$ & $632 \pm 109$ \\
\hline Taungya & $129 \pm 66$ & $45 \pm 26$ & $280 \pm 280$ & $23 \pm 13$ & $8 \pm 8$ & $8 \pm 8$ & $32 \pm 7$ & $524 \pm 320$ \\
\hline Pioneira/Tardia & $15 \pm 8$ & $61 \pm 20$ & $0 \pm 0$ & $83 \pm 42$ & $8 \pm 8$ & $30 \pm 8$ & $23 \pm 13$ & $220 \pm 76$ \\
\hline Restauração & $0 \pm 0$ & $80 \pm 41$ & $0 \pm 0$ & $45 \pm 35$ & $0 \pm 0$ & $30 \pm 20$ & $30 \pm 15$ & $187 \pm 66$ \\
\hline Fragmento & $311 \pm 151$ & $30 \pm 20$ & $0 \pm 0$ & $0 \pm 0$ & $45 \pm 35$ & $23 \pm 23$ & $76 \pm 27$ & $485 \pm 122$ \\
\hline Revegetação & $80 \pm 31$ & $58 \pm 24$ & $153 \pm 77$ & $52 \pm 28$ & $17 \pm 4$ & $22 \pm 1$ & $47 \pm 10$ & $429 \pm 90$ \\
\hline \multirow[t]{2}{*}{ Média } & $119 \pm 33$ & $54 \pm 21$ & $128 \pm 64$ & $43 \pm 23$ & $21 \pm 9$ & $22 \pm 4$ & $52 \pm 11$ & $438 \pm 95$ \\
\hline & \multicolumn{8}{|c|}{ Terceira Amostragem (Ago/00) } \\
\hline Testemunha & $121 \pm 42$ & $38 \pm 20$ & $8 \pm 8$ & $53 \pm 27$ & $23 \pm 13$ & $38 \pm 27$ & $23 \pm 0$ & $304 \pm 62$ \\
\hline Sem.Direta & $8 \pm 8$ & $36 \pm 14$ & $197 \pm 197$ & $0 \pm 0$ & $23 \pm 13$ & $8 \pm 8$ & $15 \pm 15$ & $287 \pm 182$ \\
\hline Taungya & $68 \pm 68$ & $61 \pm 61$ & $0 \pm 0$ & $8 \pm 8$ & $8 \pm 8$ & $15 \pm 15$ & $8 \pm 8$ & $167 \pm 75$ \\
\hline Pioneira/Tardia & $15 \pm 8$ & $38 \pm 8$ & $0 \pm 0$ & $0 \pm 0$ & $0 \pm 0$ & $8 \pm 8$ & $8 \pm 8$ & $69 \pm 23$ \\
\hline Restauração & $106 \pm 106$ & $38 \pm 20$ & $184 \pm 184$ & $167 \pm 99$ & $8 \pm 8$ & $8 \pm 8$ & $8 \pm 4$ & $519 \pm 246$ \\
\hline Fragmento & $38 \pm 27$ & $38 \pm 27$ & $0 \pm 0$ & $8 \pm 8$ & $15 \pm 8$ & $0 \pm 0$ & $15 \pm 8$ & $114 \pm 39$ \\
\hline Revegetação & $64 \pm 29$ & $46 \pm 6$ & $78 \pm 76$ & $45 \pm 16$ & $12 \pm 5$ & $15 \pm 4$ & $12 \pm 4$ & $269 \pm 60$ \\
\hline \multirow[t]{2}{*}{ Média } & $59 \pm 20$ & $44 \pm 4$ & $65 \pm 63$ & $39 \pm 15$ & $13 \pm 5$ & $13 \pm 3$ & $13 \pm 4$ & $244 \pm 54$ \\
\hline & \multicolumn{8}{|c|}{ Quarta Amostragem (Mar/01) } \\
\hline Testemunha & $0 \pm 0$ & $98 \pm 53$ & $0 \pm 0$ & $303 \pm 8$ & $0 \pm 0$ & $15 \pm 15$ & $30 \pm 30$ & $447 \pm 87$ \\
\hline Sem.Direta & $8 \pm 8$ & $30 \pm 30$ & $8 \pm 8$ & $265 \pm 165$ & $0 \pm 0$ & $0 \pm 0$ & $8 \pm 8$ & $318 \pm 159$ \\
\hline Taungya & $129 \pm 129$ & $23 \pm 13$ & $0 \pm 0$ & $386 \pm 95$ & $0 \pm 0$ & $8 \pm 8$ & $0 \pm 0$ & $545 \pm 159$ \\
\hline Pioneira/Tardia & $53 \pm 42$ & $8 \pm 8$ & $0 \pm 0$ & $235 \pm 15$ & $0 \pm 0$ & $0 \pm 0$ & $0 \pm 0$ & $295 \pm 52$ \\
\hline Restauração & $0 \pm 0$ & $8 \pm 8$ & $0 \pm 0$ & $386 \pm 82$ & $0 \pm 0$ & $0 \pm 0$ & $15 \pm 8$ & $409 \pm 80$ \\
\hline Fragmento & $0 \pm 0$ & $30 \pm 8$ & $0 \pm 0$ & $76 \pm 46$ & $45 \pm 35$ & $15 \pm 8$ & $174 \pm 33$ & $341 \pm 52$ \\
\hline Revegetação & $38 \pm 25$ & $33 \pm 19$ & $2 \pm 2$ & $315 \pm 12$ & $0 \pm 0$ & $5 \pm 5$ & $11 \pm 6$ & $403 \pm 42$ \\
\hline Média & $32 \pm 21$ & $33 \pm 17$ & $1 \pm 1$ & $275 \pm 17$ & $8 \pm 6$ & $6 \pm 5$ & $38 \pm 8$ & $393 \pm 30$ \\
\hline
\end{tabular}


Tabela 10. Densidades observadas (média \pm erro-padrão) para a ocorrência de grupos de macrofauna no PVA, nos diferentes tratamentos e épocas de amostragem.

\begin{tabular}{|c|c|c|c|c|c|c|c|c|}
\hline \multirow[b]{2}{*}{ Tratamento } & \multicolumn{7}{|c|}{ Grupo de Macrofauna } & \multirow[b]{2}{*}{ Total } \\
\hline & Formicidae & Coleoptera & Isoptera & Oligochaeta & Diplopoda & Chilopoda & Outros & \\
\hline & \multicolumn{8}{|c|}{ Número de indivíduos $\mathrm{m}^{2}$} \\
\hline & \multicolumn{8}{|c|}{ Primeira Amostragem (Dez/98) } \\
\hline Demais Trat. & $59 \pm 19$ & $53 \pm 11$ & $30 \pm 21$ & $13 \pm 13$ & $9 \pm 9$ & $0 \pm 0$ & $17 \pm 11$ & $181 \pm 16$ \\
\hline Sem.Direta & $115 \pm 45$ & $76 \pm 27$ & $159 \pm 89$ & $11 \pm 6$ & $6 \pm 6$ & $0 \pm 0$ & $11 \pm 6$ & $378 \pm 148$ \\
\hline Fragmento & $63 \pm 38$ & $30 \pm 15$ & $23 \pm 11$ & $45 \pm 35$ & $15 \pm 15$ & $0 \pm 0$ & $25 \pm 13$ & $201 \pm 74$ \\
\hline Revegetação & $87 \pm 31$ & $64 \pm 18$ & $95 \pm 37$ & $12 \pm 4$ & $8 \pm 4$ & $0 \pm 0$ & $14 \pm 8$ & $280 \pm 78$ \\
\hline \multirow[t]{2}{*}{ Média } & $79 \pm 23$ & $53 \pm 7$ & $71 \pm 22$ & $23 \pm 11$ & $10 \pm 6$ & $0 \pm 0$ & $18 \pm 7$ & $253 \pm 45$ \\
\hline & \multicolumn{8}{|c|}{ Segunda Amostragem (Jul/99) } \\
\hline Testemunha & $114 \pm 114$ & $189 \pm 40$ & $0 \pm 0$ & $45 \pm 26$ & $0 \pm 0$ & $0 \pm 0$ & $23 \pm 13$ & $372 \pm 156$ \\
\hline Sem.Direta & $242 \pm 147$ & $91 \pm 26$ & $61 \pm 61$ & $0 \pm 0$ & $0 \pm 0$ & $0 \pm 0$ & $8 \pm 8$ & $402 \pm 122$ \\
\hline Taungya & $8 \pm 8$ & $83 \pm 15$ & $0 \pm 0$ & $8 \pm 8$ & $0 \pm 0$ & $0 \pm 0$ & $0 \pm 0$ & $98 \pm 20$ \\
\hline Pioneira/Tardia & $136 \pm 125$ & $83 \pm 40$ & $0 \pm 0$ & $0 \pm 0$ & $0 \pm 0$ & $0 \pm 0$ & $0 \pm 0$ & $220 \pm 163$ \\
\hline Restauração & $0 \pm 0$ & $136 \pm 60$ & $45 \pm 45$ & $8 \pm 8$ & $8 \pm 8$ & $0 \pm 0$ & $8 \pm 8$ & $204 \pm 52$ \\
\hline Fragmento & $8 \pm 8$ & $15 \pm 8$ & $0 \pm 0$ & $0 \pm 0$ & $15 \pm 8$ & $15 \pm 8$ & $30 \pm 20$ & $83 \pm 8$ \\
\hline Revegetação & $100 \pm 30$ & $117 \pm 24$ & $21 \pm 11$ & $12 \pm 3$ & $2 \pm 2$ & $0 \pm 0$ & $8 \pm 2$ & $259 \pm 53$ \\
\hline \multirow[t]{2}{*}{ Média } & $85 \pm 24$ & $100 \pm 20$ & $18 \pm 9$ & $10 \pm 3$ & $4 \pm 2$ & $3 \pm 1$ & $11 \pm 4$ & $230 \pm 43$ \\
\hline & \multicolumn{8}{|c|}{ Terceira Amostragem (Ago/00) } \\
\hline Testemunha & $0 \pm 0$ & $106 \pm 15$ & $227 \pm 125$ & $8 \pm 8$ & $23 \pm 23$ & $0 \pm 0$ & $30 \pm 8$ & $394 \pm 112$ \\
\hline Sem.Direta & $8 \pm 8$ & $30 \pm 20$ & $0 \pm 0$ & $8 \pm 8$ & $15 \pm 15$ & $0 \pm 0$ & $106 \pm 59$ & $167 \pm 67$ \\
\hline Taungya & $23 \pm 23$ & $30 \pm 19$ & $8 \pm 8$ & $30 \pm 30$ & $0 \pm 0$ & $0 \pm 0$ & $38 \pm 8$ & $129 \pm 51$ \\
\hline Pioneira/Tardia & $45 \pm 45$ & $23 \pm 23$ & $0 \pm 0$ & $0 \pm 0$ & $8 \pm 8$ & $0 \pm 0$ & $38 \pm 15$ & $114 \pm 80$ \\
\hline Restauração & $8 \pm 8$ & $61 \pm 27$ & $8 \pm 8$ & $8 \pm 8$ & $0 \pm 0$ & $0 \pm 0$ & $23 \pm 13$ & $106 \pm 27$ \\
\hline Fragmento & $0 \pm 0$ & $38 \pm 15$ & $15 \pm 15$ & $8 \pm 8$ & $30 \pm 15$ & $0 \pm 0$ & $23 \pm 23$ & $114 \pm 23$ \\
\hline Revegetação & $17 \pm 8$ & $50 \pm 11$ & $48 \pm 26$ & $11 \pm 7$ & $9 \pm 5$ & $0 \pm 0$ & $47 \pm 18$ & $182 \pm 29$ \\
\hline \multirow[t]{2}{*}{ Média } & $14 \pm 7$ & $48 \pm 11$ & $43 \pm 24$ & $10 \pm 7$ & $13 \pm 6$ & $0 \pm 0$ & $43 \pm 12$ & $171 \pm 22$ \\
\hline & \multicolumn{8}{|c|}{ Quarta Amostragem (Mar/01) } \\
\hline Testemunha & $8 \pm 8$ & $91 \pm 35$ & $0 \pm 0$ & $23 \pm 13$ & $8 \pm 8$ & $8 \pm 8$ & $38 \pm 15$ & $174 \pm 55$ \\
\hline Sem.Direta & $8 \pm 8$ & $61 \pm 27$ & $0 \pm 0$ & $15 \pm 15$ & $15 \pm 15$ & $0 \pm 0$ & $30 \pm 15$ & $129 \pm 42$ \\
\hline Taungya & $159 \pm 159$ & $68 \pm 23$ & $0 \pm 0$ & $83 \pm 72$ & $0 \pm 0$ & $8 \pm 8$ & $15 \pm 8$ & $333 \pm 171$ \\
\hline Pioneira/Tardia & $8 \pm 8$ & $30 \pm 15$ & $0 \pm 0$ & $23 \pm 13$ & $0 \pm 0$ & $0 \pm 0$ & $45 \pm 13$ & $106 \pm 33$ \\
\hline Restauração & $0 \pm 0$ & $38 \pm 15$ & $0 \pm 0$ & $30 \pm 20$ & $0 \pm 0$ & $8 \pm 8$ & $0 \pm 0$ & $76 \pm 30$ \\
\hline Fragmento & $0 \pm 0$ & $0 \pm 0$ & $0 \pm 0$ & $0 \pm 0$ & $8 \pm 8$ & $8 \pm 8$ & $98 \pm 40$ & $114 \pm 35$ \\
\hline Revegetação & $36 \pm 34$ & $58 \pm 16$ & $0 \pm 0$ & $35 \pm 19$ & $5 \pm 3$ & $5 \pm 3$ & $26 \pm 4$ & $164 \pm 44$ \\
\hline Média & $30 \pm 28$ & $48 \pm 13$ & $0 \pm 0$ & $29 \pm 16$ & $5 \pm 3$ & $5 \pm 3$ & $38 \pm 10$ & $155 \pm 42$ \\
\hline
\end{tabular}


Tabela 11. Densidades observadas (média \pm erro-padrão) para a ocorrência de grupos de macrofauna, no LVA, nos diferentes tratamentos e épocas de amostragem.

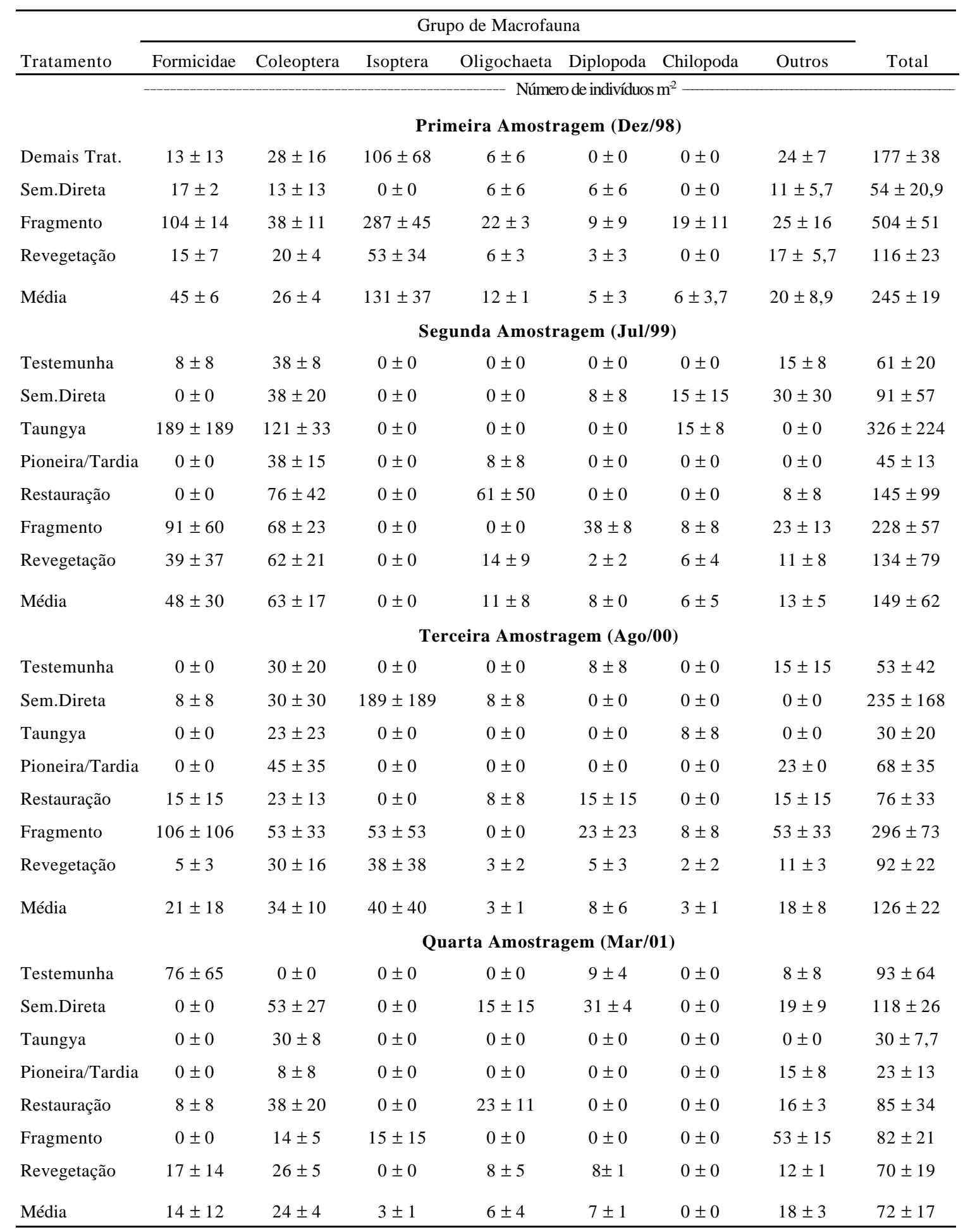


$\mathrm{Na}$ média de todas as amostragens, a densidade total de macrofauna no NV e PVA foi maior no Testemunha, seguido pelo Sem.Direta e Taungya. No LVA, a maior densidade de macroinvertebrados foi encontrada no Fragmento e, somente neste solo, foi superior ao Revegetação (Figura 17). Como para acarofauna, a relevância dos tratamentos Testemunha e Sem.Direta se deu pelas condições intrínsecas de cada tratamento. O agrupamento fornecido pela análise de Cluster, que classifica os tratamentos em grupos homogêneos, também confere um destaque expressivo a esses tratamentos (Figura 18). No NV, reúne num só grupo, os tratamentos Testemunha, Sem.Direta, Taungya, Restauração e Fragmento, com quase $80 \%$ de similaridade, e separa o Pioneira/Tardia, tratamento com menor densidade e $70 \%$ distante dos demais. O Testemunha e o Sem.Direta possuem cerca de $65 \%$ de similaridade no PVA e, juntos, estão distantes $80 \%$ do Fragmento, tratamento com a menor densidade de macrofauna. No LVA, a análise formou dois grupos, um formado exclusivamente pelo Fragmento, com mais de $60 \%$ de similaridade com o outro grupo.

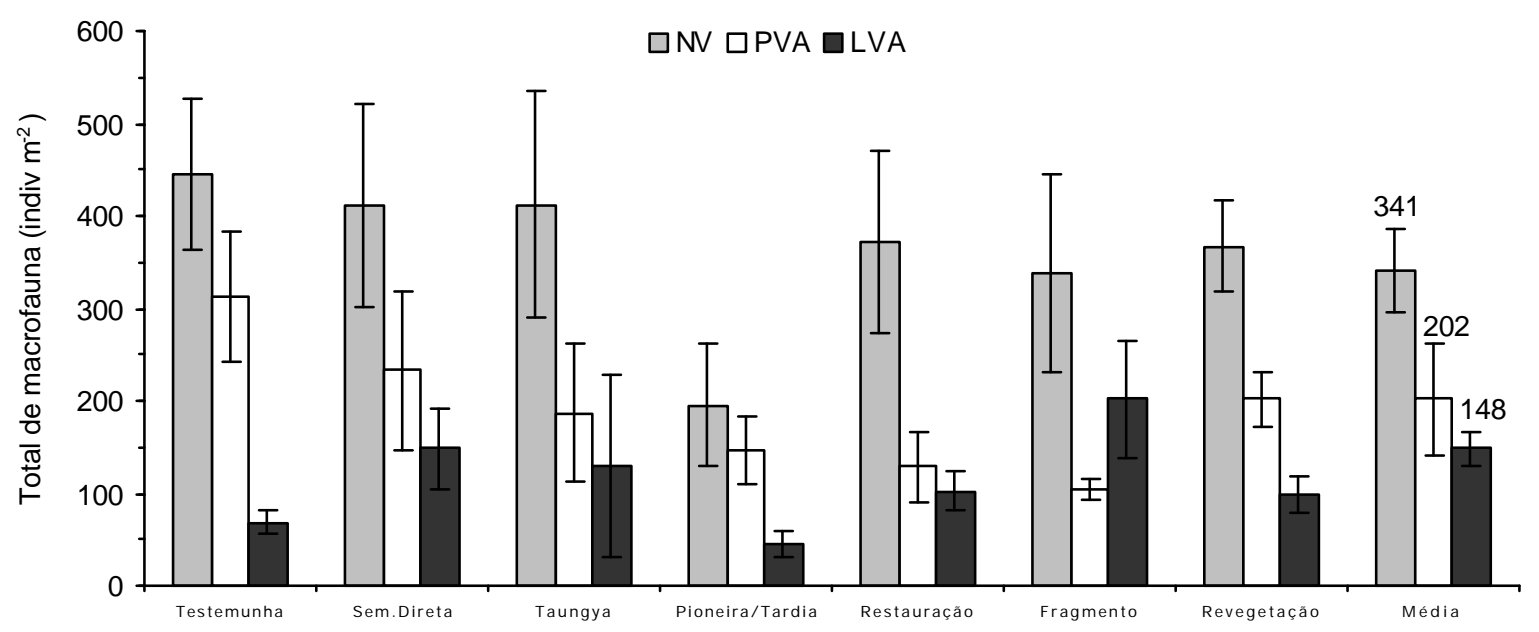

Figura 17 - Densidade total (média \pm erro-padrão) de macrofauna em cada tratamento na média de todas as amostragens, e densidade média (média \pm erro-padrão) de cada solo. 


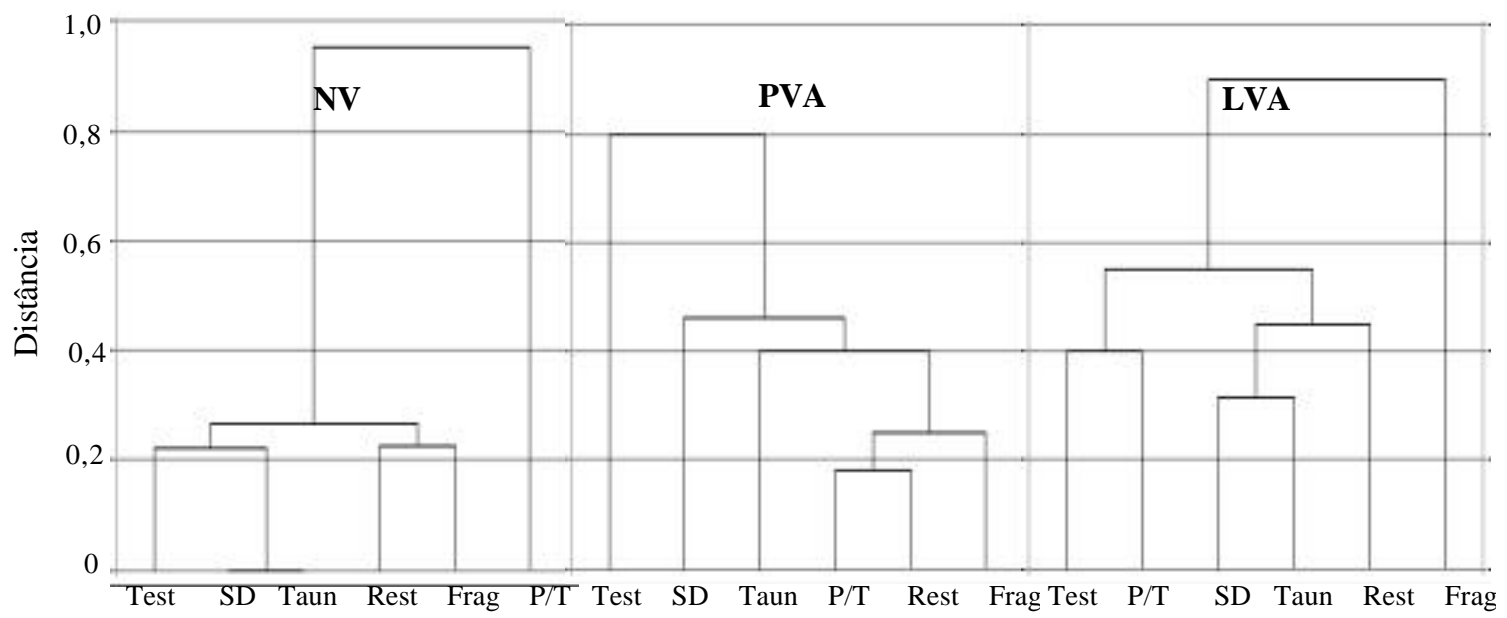

Figura 18 - Dendrogramas obtidos pela análise de Cluster para densidade de macrofauna na média de todas as amostragens, discriminando os tratamentos ${ }^{5}$ para os três solos, utilizando-se a Distância Euclidiana e a Ligação Simples.

${ }^{5}$ Abreviações dos tratamentos: Test $=$ Testemunha; $\mathrm{SD}=$ Sem. Direta; Taun = Taungya; $\mathrm{P} / \mathrm{T}=$ Pioneira/Tardia; Rest $=$ restauração; Frag $=$ Fragmento

Em várias amostras não foram encontrados os macroinvertebrados estudados. $\mathrm{A}$ quantidade de amostras sem esses organismos no Fragmento foi sempre menor que no Revegetação (Figura 19), diferentemente do verificado para a densidade desses animais no solo. Isto porque, mesmo encontrando menos amostras com macroinvertebrados no Revegetação do NV e PVA, a quantidade de indivíduos coletadas por amostras foi elevada, possivelmente por causa da distribuição espacial dos grupos de macrofauna, face a microhabitats heterogêneos no solo. Em todos os solos, portanto, a permanência da fauna de invertebrados na camada $0-15 \mathrm{~cm}$ foi afetada sensivelmente pelas perturbações ocorridas nas áreas degradadas. 


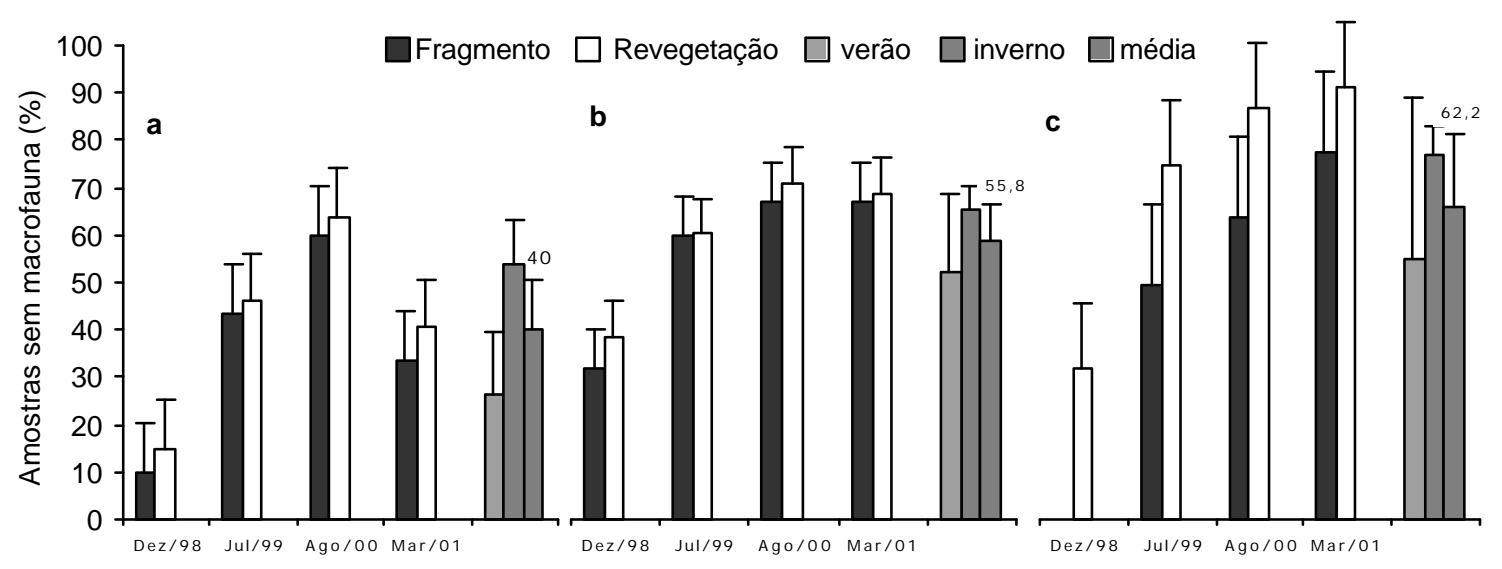

Figura 19 - Quantidade de amostras sem macroinvertebrados (média + erro-padrão) nos tratamentos Fragmento e Revegetação, nas diferentes épocas de amostragem, no a) NV, b) PVA e c) LVA.

A menor densidade de macroinvertebrados e a maior quantidade de amostras sem macrofauna edáfica (40, 56 e $62 \%$ para NV, PVA e LVA, respectivamente), foram observadas no LVA (Figura 17). Neste solo, foi verificado baixo teor de matéria orgânica, menor fertilidade e a maior acidez do solo (Tabela 6); além disso, nele foram observadas as maiores temperaturas do solo (Figura 13) e os mais baixos índices de estabelecimento e desenvolvimento da maioria das espécies (Tabela 7). Segundo Nogueira Junior (2000), nas mesmas áreas e épocas amostrais, nos três solos, o C da biomassa microbiana nas áreas degradadas aumentou a partir de fevereiro de 1999, indicando melhores condições edáficas para a proliferação e atividade dos microorganismos, inclusive ciclagem de nutriente. Ainda assim, o LVA foi o solo mais afetado pela mudança de ocupação (reflorestamento), inclusive em relação à mineralização de $\mathrm{N}$.

No LVA, foi verificada baixa ocorrência de minhocas (Oligochaeta), atribuída às piores condições químicas (baixo teor de matéria orgânica e nutrientes e baixo $\mathrm{pH}$ ), físicas (baixa umidade do solo e baixo teor de silte) e microbiológicas (menor teor de C da biomassa microbiana). Elas têm sua densidade favorecida em ambiente com alto teor de matéria orgânica e elevado conteúdo de água (Brady, 1983; Tibau, 1983) e por isso foram encontradas no NV, onde a umidade média do solo $(22,5 \%)$ era muito maior que no PVA e LVA, e se encontrava entre a umidade ótima para muitas espécies de 
minhocas, que é de 19 a 23\%. Geralmente há correlação positiva entre o teor de silte e a abundância de minhocas, como no NV. Em solos arenosos, com grossa textura mineral, como o PVA e LVA, as minhocas ocorrem somente em pequeno número ou são ausentes (Makeschin, 1997). Algumas espécies são bastante tolerantes a baixo pH do solo, porém a maioria se desenvolve melhor em solos menos ácidos, como no NV (Brady, 1983).

Nos três solos, a densidade de minhocas no Revegetação superou a do Fragmento, com exceção de dez/98 no LVA e PVA (Tabelas 9, 10 e 11). Tanck et al. (2000), estudando a população de oligochaeta edáfica, presente em terras sujeitas a diferentes tipos de manejo, constataram que a mata nativa e o plantio direto promoveram maior densidade populacional, pois proporcionaram melhor ambiente para a sobrevivência e reprodução dos organismos (Almeida, 1985). Ainda assim, e mesmo sendo susceptível ao ataque de certos animais (Makeschin, 1997), a maior densidade de minhocas ocorrida no Revegetação (Tabelas 9, 10 e 11) pode ter acontecido pela diminuição de alguns grupos de fauna específicos, como chilópodas e diplópodas, ou pelo aumento de outros grupos que servem de presa para as minhocas. A densidade de minhocas é freqüentemente baixa em solos compactados, sujeitos à fertilização mineral extrema, à aplicação regular de pesticidas e ao sistema de rotação de cultivo (Makeschin, 1997). Por essas razões, a densidade de minhocas encontradas no Taungya foi baixa, principalmente, no LVA, onde não foi encontrada em nenhuma das amostragens.

A densidade de diplópodas e de chilópodas é normalmente muito baixa em solos arenosos. A abundância em solos argilosos é provavelmente a combinação de dois fatores: a alta umidade, e cobertura vegetal densa e a alta produção de substâncias orgânicas, o que assegura maior suprimento de alimento (Ekschimitt et al., 1997). Também são mais vulneráveis à dissecação que aracnídeos e insetos, porque sua cutícula geralmente é mais permeável e o sistema de trocas gasosas não é fechado (Wolters \& Ekschmitt, 1997). Foram, por estas razões, mais encontrados no NV. O menor teor de Ca no PVA e LVA também pode ter contribuído para as pequenas densidades de diplópodas encontrada nestes solos em todas as amostragem, pois a preferência alimentar deste grupo recai sobre folhedo com altas concentrações de cálcio ou baixo conteúdo de 
compostos secundários (Poggiani et al., 1996). Diferentemente do ocorrido com o total de macrofauna no NV e PVA, e semelhantemente ao LVA, a densidade de diplópodas, de chilópodas e do grupo denominado "outros" foi superior no Fragmento em quase todas as amostragens (Tabelas 9, 10 e 11). Apesar de, em algumas comunidades, a densidade populacional de chilópodas não mudar muito após a perturbação, normalmente, ela é comparativamente baixa em solos agriculturáveis, como também acontece com os diplópodas, que são mais abundantes em terras não manejadas (Wolters \& Ekschmitt, 1997) e preferem ambientes sombrios e ricos em matéria orgânica em decomposição (Bernardi, 1994). A maior densidade desse grupo no Fragmento também pode ter sido resultado da maior concentração de Ca na serapilheira desse ambiente.

Assim como os diplópodas e chilópodas, muitas espécies de coleópteros preferem solos argilosos que arenosos; o adultos são menos sensíveis, mas solos excessivamente úmidos não são preferidos por estes macroinvertebrados, embora o desenvolvimento possa ocorrer (Ekschimitt et al., 1997), explicando as maiores densidades observadas no PVA, de textura média e umidade do solo inferior ao NV. A densidade de besouros no Fragmento foi inferior ao Revegetação em todas as amostragens no PVA e na grande maioria das amostragens no NV (Tabelas 9 e 10). No LVA, a maior densidade de besouros foi observada no Fragmento, com exceção de mar/01 (Tabela 11). Em geral, as comunidades com maior diversidade e complexidade estrutural da vegetação, possuem menor abundância de insetos-pragas, como alguns coleópteros (Mezzomo et al., 1998). Esse fator, associado à umidade do solo, que é fator decisivo na atividade de muitos coleópteros (Ekchimitt et al., 1997), explica a maior densidade desse organismos no Fragmento do LVA. Por outro lado, as modificações ambientais diminui a competição e favorece a proliferação de coleópteros pela disponibilidade de alimento e menor quantidade de inimigos naturais (Freitas et al., 2002). Portanto, no Revegetação do NV e PVA, além da maior umidade do solo, a oferta de alimento contribuiu para a miro densidade de coleópteros. O maior crescimento da cobertura vegetal no NV e PVA, em relação ao LVA, diminuiu o efeito da luminosidade, contribuindo, também, para maior densidade de coleópteros no Revegetação. 
Os isópteros (cupins) subterrâneos adaptam-se melhor que os demais grupos de macrofauna em solos com diferentes condições físicas e químicas, mas as proporções de areia, silte e argila exercem grande influência na densidade de indivíduos; em solos mais arenosos, não fazem galerias e, nos solos totalmente arenosos não conseguem subsistir (Forti \& Andrade, 1995). As condições de alta umidade do solo e do substrato de alimentação também intensificam a atividade dos cupins subterrâneos (Paiva, 1998), explicando a maior densidade desses organismos no NV. A densidade de cupins foi menor no Fragmento em todas as amostragens no PVA e no NV, inclusive com ausência de cupins neste último solo (Tabelas 9 e 10). No LVA, a maior densidade de cupins foi observada no Fragmento ( Tabela 11). Qualquer que seja a causa da modificação do ambiente, espera-se um total desbalanço na comunidade original (DeSouza, 1995). Os efeitos do desmatamento na eliminação de competidores e inimigos naturais, a abundância de alimento com a implantação de pastagens, e pouco sombreamento promovido pela vegetação rala, aumentam a frequiência e a densidade populacional dos cupinzeiros (Forti \& Andrade, 1995; Fernandes et al., 1998). Em Botucatu, Forti \& Andrade (1995) encontraram maior freqüência de termiteiros subterrâneos em área com vegetação totalmente aberta, do que em floresta com vegetação densa, concluindo, portanto, que em áreas perturbadas, como vegetação secundária, o número de termiteiros $\mathrm{ha}^{-1}$ geralmente é maior que em áreas não perturbadas. Esses apontamentos explicam a maior densidade de cupins encontrados no Revegetação do NV e PV. No LVA, as maiores diferenças das características físicas e químicas entre o Fragmento e o Revegetação, e as poucas e pobres ofertas de alimento, fizeram com que a densidade de térmitas não sofresse alterações drásticas e se mantivesse maior no Fragmento. Para isso, cupinzeiro forma um sistema fechado, onde o microclima pode ser controlado e o alimento armazenado, ficando protegido, inclusive, de inimigos naturais, como aranhas, vespas, besouros, e formigas (Berti Filho, 1993; Wilcken \& Raetano, 1995).

As formigas geralmente exploram ambientes que possuam alimentos de alta qualidade (Della Lucia \& Araújo, 1993), como a encontrada na serapilheira do NV. Também têm sua atividade correlacionada com parâmetros climáticos. As saúvas, por exemplo, têm picos de atividade entre 15 e $25^{\circ} \mathrm{C}$ (Berti Filho et al., 1992), e encontram 
no NV as melhores condições para a proliferação de sua população. A densidade de formigas (Formicidae) no Fragmento foi inferior ao Revegetação em todas as amostragens no PVA e na maioria das amostragens no NV (Tabelas 9 e 10). No LVA, as formigas foram observadas em maior quantidade no Fragmento, com exceção da primeira amostragem (Tabela 11). Mesmo causando desestruturação temporal da comunidade de Formicidae, a eliminação de sub-bosque ou o manejo antrópico de ecossistemas naturais reduz os competidores e inimigos naturais, fornecendo à formigas e à muitos outros organismos da fauna do solo, o meio ideal para a propagação e ocupação de áreas antes não ocupadas, ou ocupadas em baixas densidades (Della Lucia \& Fowler, 1993; Ramos, 2001), como ocorreu no Revegetação do NV e PVA. No ambiente revegetado do LVA, com menos fonte de alimento e de pior qualidade, as formigas foram encontradas em menor quantidade. No Fragmento, a população desses organismos foi muito maior.

Na média dos tratamentos, em todos os solos, os maiores valores de erro-padrão foram os observados para os grupos Formicidae e Isoptera, atribuído ao fato desses insetos serem sociais e formarem padrões agregados (Bernardi, 1994).

A participação de cada grupo no total de macrofauna edáfica foi bastante variada em cada amostragem e, na média de todas as amostragens os besouros, em seguida as formigas, foram observados com maior densidade no PVA; no LVA, os macroinvertebrados mais abundantes foram os cupins, seguidos pelos besouros e formigas (Figura 20). As minhocas encontradas no NV, pouco representativas nos demais solos, foram as que apresentaram a maior densidade média de indivíduos, com quase $30 \%$ do total de macrofauna (Figura 20), resultado da amostragem de mar/01, onde a participação de minhocas superou $70 \%$ do total de macroinvertebrados. A variação na composição da fauna de macroinvertebrados também foi descrita por Lopes Assad (1997), que em alguns estudos conduzidos em pequenas áreas de amostragem, demonstrou que diferentes grupos de macrofauna de invertebrados aparecem em quantidade variável conforme o tipo de solo e seu uso. Berti Filho (1995) descreve que os insetos são os organismos mais abundantes nas comunidades florestais e, Dias et al. (1996), estudando a densidade de macrofauna invertebrada em áreas com diferentes 
fitofisionomias, no Distrito Federal, constataram que os grupos taxonômicos predominantes apresentavam uma composição variável em relação ao número de indivíduos comparado ao total de indivíduos, embora os cupins tenham predominado em todas as áreas, e os coleópteros tenham compreendido de 1 a $41 \%$ do total de macroinvertebrados. Tanto pela abundância e quanto pela diversidade, as formigas também podem compor uma parte da fauna da serapilheira extremamente comum e importante (Poggiani et al., 1996; Lopes Assad, 1997), podendo constituir-se no grupo de macroinvertebrados com maior densidade de indivíduos no solo.

Os diplópodas e chilópodas foram os grupos menos dominantes numericamente (Figura 20), com percentagens máximas de 5,2 e 3,6\%, respectivamente, obtidas no NV (Figuras 20). Estes dois grupos de macrofauna edáfica também foram os que sofreram menores variações entre os solos, com menos de três pontos percentuais. Battigelli et al. (1994), estudando a fauna do solo em dois tipos distintos de florestas, no Canadá, observaram que os diplópodas representaram grande parte da biomassa total, mas foram responsáveis por menos que $0,01 \%$ do número total da fauna do solo. Bernardi (1994) também encontrou poucos animais da classe Diplopoda em estudo sobre artrópodos de solo, em um talhão do híbrido Eucalyptus grandis vs. urophylla.

A densidade total de macrofauna obtida nas amostragens de verão foi superior às de inverno apenas no LVA, com $54 \%$ do total observado. No NV e no PVA, não houve influência da época de amostragem no total de macroinvertebrados capturados, sendo encontrados $50 \%$ do total de indivíduos em cada época amostral. Estes resultados evidenciam que a influência sazonal sobre o total de macroinvertebrados foi mais acentuada no solo arenoso (LVA), onde o teor de matéria orgânica é menor e as variações térmicas e hídricas entre as estações seca e úmida são elevadas. 


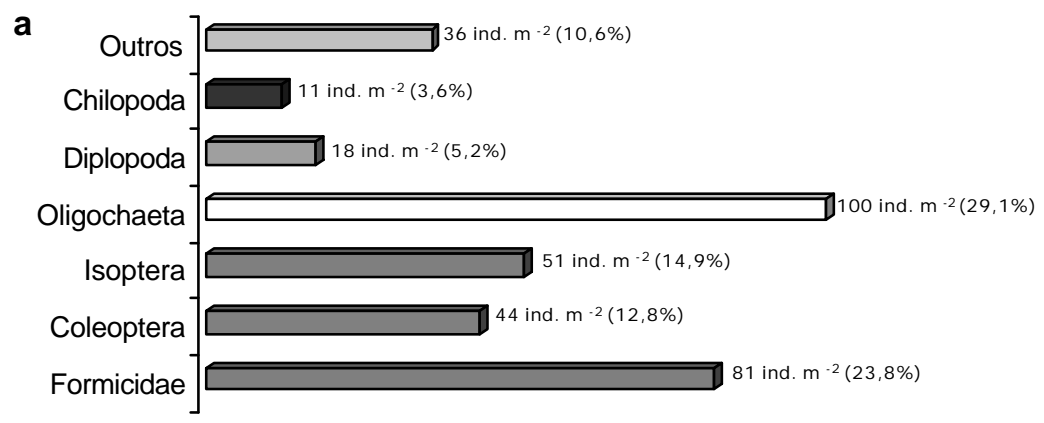

b

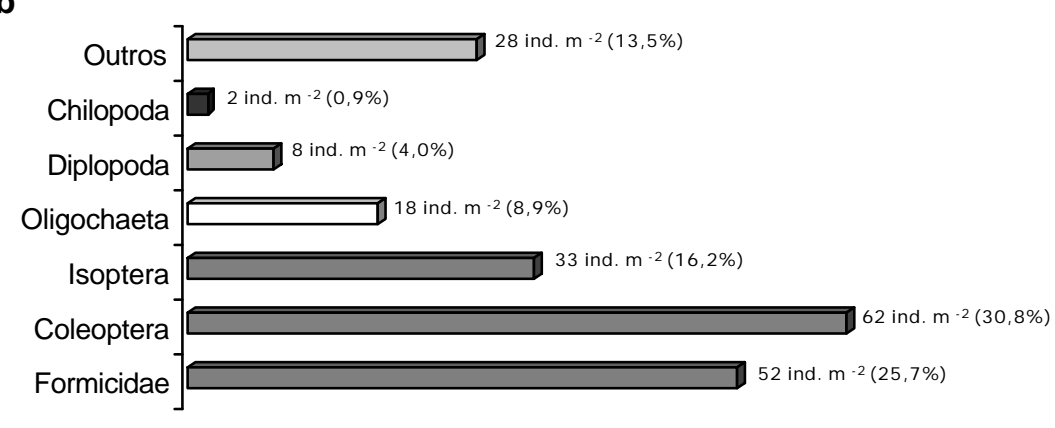

c

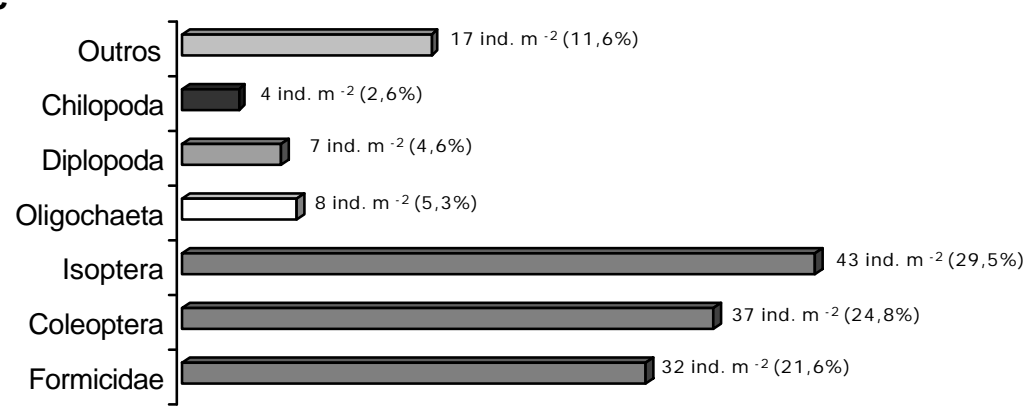

Figura 20 - Participação de cada grupo de macrofauna edáfica na média das amostragens, nos solos: a) NV, b) PVA e c) LVA

Numericamente, na média de todos os solos a maior quantidade de macroinvertebrados foi observada no verão (Figura 21). Isso pode ser explicado pelo comportamento dos grupos mais representativos, como as minhocas (máxima atividade na primavera e no outono, Brady, 1983), a maioria das espécies de coleópteros (procriam na primavera, Ekschimitt et al., 1997) e os cupins (maior atividade nos meses quentes e chuvosos, Fernandes et al., 1998). Também pode estar relacionado, além das características edafoclimáticas, com o aumento da atividade de raízes e do crescimento 
de fungos, que são recursos alimentícios para muitos animais do solo (Battigelli et al., 1994).
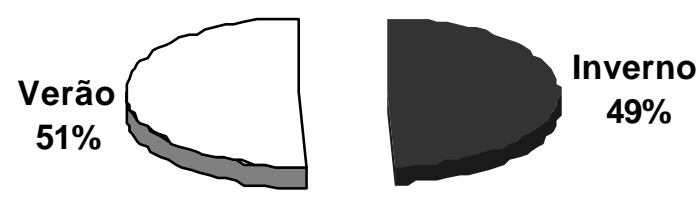

Figura 21 - Distribuição sazonal do total de macrofauna edáfica, média de todos os solos.

Ao contrário da densidade total, a quantidade de amostras sem macroinvertebrados encontrada no verão foi menor que a encontrada no inverno (Figura 19), revelando a influência direta da maior temperatura e umidade do solo sobre a permanência desses macroinvertebrados nas camadas mais superiores do solo. Estas flutuações da população de fauna do solo nos horizontes superficiais pode ser resultado da migração da fauna para a obtenção de recursos alimentícios, ou mudanças na mortalidade e natalidade dependendo da época do ano, ou devido a acontecimentos específicos (Battigelli et al., 1994). Ocorre, por exemplo, com as minhocas, que na estação seca, tendem a buscar abrigo nas camadas mais úmidas do solo (Lopes Assad, 1997), podendo penetrar de 1 a $2 \mathrm{~m}$ em regiões temperadas (Brady, 1983). Algumas espécies de coleópteros têm migração sazonal (Ekschimitt et al., 1997) e, os térmitas subterrâneos, que se caracterizam por seu grande poder de dispersão horizontal e vertical (Fontes, 1995), tem sua distribuição no perfil influenciada pela temperatura do solo (Brady, 1983). 


\section{CONCLUSÕES}

- Nos tratamentos com cobertura vegetal mais densa e solo menos perturbado (Fragmento, Testemunha e Sem.Direta), foram verificadas as maiores densidades de organismos da meso e macrofauna edáfica;

- Houve uma relação direta entre a densidade de organismos e os atributos físicos e químicos dos solos. No solo mais úmido, de menor temperatura média, mais permeável, mais fértil e mais rico em matéria orgânica $(\mathrm{NV})$, foram encontradas as maiores densidades de organismos da meso e macrofauna edáfica e, no LVA, as menores densidades;

- Dentre as subordens de mesofauna, os oribatídeos foram encontrados com maior densidade em todos os solos e, os Astigmatas e Prostigmatas, em menores quantidades. Na média de todos os solo, foi observada a proporção de: oribatídeos $55,9 \%$, mesostigmata $37,3 \%$, astigmatas $6,6 \%$, e prostigmatas $1,2 \%$;

- O grupo das Oligochaetas foi o mais encontrado no NV (29\%), seguido do Formicidae (24\%). Os grupos Isoptera, 16 e 29\%, Coleoptera, 31 e 25\%, e Formicidae, 26 e $22 \%$, foram os mais encontrados no PVA e LVA, respectivamente. Não ocorreu, entre os solos, um padrão na participação de cada grupo;

- Independente do tipo de solo, a densidade de organismos da mesofauna edáfica foi maior no verão que no inverno. Para a macrofauna, as variações estacionais da densidade de organismos ocorreram somente no LVA, com 54\% no verão, e foram influenciadas pelas condições físicas e químicas do solo. 


\section{REFERÊNCIAS BIBLIOGRÁFICAS}

ALMEIDA, F.S. Influência da cobertura morta do plantio direto na biologia do solo. In: SIMPÓSIO SOBRE O POTENCIAL AGRÍCOLA DOS CERRADOS, 1., Goiânia, 1985. Anais. Campinas: Fundação Cargill/Empresa Goiana de Pesquisas Agropecuária, 1985. p.109-150.

ARCOVA, F.C.S. Balanço hídrico, características do deflúvio e calibragem de duas microbacias hidrográficas na serra do mar, SP. Piracicaba, 1996. 130p. Dissertação (Mestrado) - Escola Superior de Agricultura "Luiz de Queiroz", Universidade de São Paulo.

BACHA, C.J.C. A dinâmica do desmatamento e do reflorestamento no Brasil. Piracicaba, 1993. 236p. Dissertação (Livre Docência) - Escola Superior de Agricultura "Luiz de Queiroz", Universidade de São Paulo.

BATTIGELLI, J.P.; BERCH, S.M.; MARSHALL, V.G. Soil fauna communities two distinct but adjacent forest types on northern Vancouver Island, British Columbia. Canadian Journal of Forest Research, v.24, n.8, p.1557-1566, Aug. 1994.

BERNARDI, J.V.O. A importância dos resíduos florestais para a fauna envolvida na conservação dos solos. O papel, v.55, n.11, p.41-49, nov. 1994.

BERTI FILHO, E. (Coord.). Manual de pragas em florestas: cupins ou térmitas. Piracicaba: IPEF/SIF, 1993 v.3, 56 p. 
BERTI FILHO, E. Cupins em florestas. In: BERTI FILHO, E; FONTES, L.R. (Ed.). Alguns aspectos atuais da biologia e controle de cupins. Piracicaba: FEALQ, 1995. p. 127-140.

BERTI FILHO, E.; MARCHINI, L.C.; NAKANO, O. Formigas cortadeiras e cupins. In: CURSO DE ENTOMOLOGIA APLICADA À AGRICULTURA, Piracicaba, 1992. Piracicaba: FEALQ, 1992. p.631-672.

BRADY, N.C. Natureza e propriedades dos solos. 7.ed. Rio de Janeiro: Freitas Bastos, 1983. 878p.

BUSCHBACHER, R. (Coord.). $\mathbf{5 0 0}$ anos de destruição ambiental no Brasil: um balanço do meio ambiente. Brasília: WWF-Brasil, 2000. 24 p.

BZUNECK, H.L.; SANTOS, H.R. Efeitos de dois sistemas de preparo do solo e de sucessões de culturas na população dos colêmbolos Dicranocentrus spp. Revista do Setor de Ciências Agrárias, v. 11, n.1/2, p.231-235, 1989/1991.

CARDOSO, E.J.B.N. Ecologia microbiana do solo. In: CARDOSO, E.J.B.N.; TSAI, S.M.; NEVES, M.C.P. (Coord.) Microbiologia do solo. Campinas:SBCS, 1992. cap.3, p.33-39.

COLEMAN, D.C.; CROSSLEY, D.A. Fundamentals on soil ecology. London: Academic Press, 1996. 205p.

CURRY, J.P.; GOOD, J. A soil faunal degradation and restoration. Advances in Soil Science, v.17, p. 171-215, 1992. 
DELLA LUCIA, T.M.C.; ARAÚJO, M.S. Fundação e estabelecimento de formigueiros. In: DELLA LUCIA, T.M.C. (Ed.) As formigas cortadeiras. Viçosa: Folha de Viçosa, 1993. cap.7, p.60-83.

DELLA LUCIA, T.M.C.; FOWLER, H.G. As formigas cortadeiras. In: DELLA LUCIA, T.M.C. (Ed.) As formigas cortadeiras. Viçosa: Folha de Viçosa, 1993. cap.1, p.1-3.

DeSOUZA, O. Efeitos da fragmentação de ecossistemas em comunidades de cupins. In: BERTI FILHO, E; FONTES, L.R. (Ed.). Alguns aspectos atuais da biologia e controle de cupins. Piracicaba: FEALQ, 1995. p. 19-27.

DIAS, V.S.; BROSSARD, M.; LOPES ASSAD, M.L. Avaliação preliminar da macrofauna edáfica invertebrada em áreas de vegetação nativa da região do Cerrado. In: CONGRESSO DE ECOLOGIA DO BRASIL, 3., Brasília, 1996. Manejo de ecossistemas e mudanças globais; resumos. Brasília: UnB, 1996. p.137-138.

EKSCHIMITT, K.; WOLTERS, V.; WEBER, M. Spiders, Carabids, and Staphylinids: the ecological potential of predatory macroarthropods. In: BENCKISER, G. (Ed.). Fauna in soil ecosystems: recycling processes, nutrient fluxes, and agricultural production. New York: Marcel Dekker, 1997. cap.9, p. 307-362.

EMPRESA BRASILEIRA DE PESQUISA AROPECUÁRIA. Centro Nacional de Pesquisa de Solos. Sistema brasileiro de classificação de solos. Brasília, 1999. 412p. 
ENGEL, V.L.; PARROTA, J.A. An evaluation of direct seeding for reforestation of degraded lands in central São Paulo State, Brazil. Forest Ecology and Management, n.152, p.169-181, Sept. 2001.

FISHER, R.F.; BINKLEY, D. Ecology and management of forest soils. 3.ed. London: John Wiley, 2000. 489p.

FLECHTMANN, C.H.W. Elementos de acarologia. São Paulo: Nobel, 1975. 344p.

FLECHTMANN, C.H.W. Ácaros de importância agrícola. 5.ed. São Paulo: Nobel, 1983.

FERNANDES, P.M.; CZEPAK, C.; VELOSO, V.R.S. Cupins de montículos em pastagens: prejuízo real au praga estética? In: FONTES, L. R.; BERTI FILHO, E. (Ed.). Cupins: o desafio do conhecimento. Piracicaba: FEALQ, 1998. p. 187210 .

FONTES, L.R. Termites (Isoptera) que causan infestación en Brasil. In: BERTI FILHO, E; FONTES, L.R. (Ed.). Alguns aspectos atuais da biologia e controle de cupins. Piracicaba: FEALQ, 1995. p. 161-162.

FORTI, L.C.; ANDRADE, M.L. Populações de cupins. In: BERTI FILHO, E; FONTES, L.R. (Ed.). Alguns aspectos atuais da biologia e controle de cupins. Piracicaba: FEALQ, 1995. p. 29-51.

FREITAS, F.A.; ZANUNCIO, T.V.; LACERDA, M. C. et al. Fauna de coleoptera coletada com armadilhas ; luminosas em plantios de Eucalyptus grandis em Santa Bárbara, Minas Gerais. Revista Árvore, v.26, n.4, p. 505-511, jul./ago. 2002. 
GALLO, D.; NAKANO, O; SILVEIRA NETO, S. et al. Manual de entomologia agrícola. São Paulo: Agronômica Ceres, 1978. 531p.

GONÇALVES, J.L.M.; STAPE, J.L.; BENEDETTI, V. et al. Reflexos do cultivo mínimo e intensivo do solo em sua fertilidade e na nutrição das árvores. In: GONÇALVES, J.L.M.; BENEDETTI, V. (Eds.). Nutrição e fertilização florestal. Piracicaba: IPEF, 2000. cap.1, p. 1-57.

GRIFFITH, J.J.; DIAS, L.E.; JUCKSCH, I. Novas estratégias ecológicas para a revegetação de áreas mineradas no Brasil. h: SIMPÓSIO SUL-AMERICANO, 1; SIMPÓSIO NACIONAL DE RECUPERAÇÃO DE ÁREAS DEGRADADAS, 2., Foz de Iguaçu, 1994. Anais. Curitiba: FUPEF, 1994. p. 31-43.

GUERRA, R.T.; BUENO, C.R.; SCHUBART, H.O. Avaliação preliminar sobre os efeitos da aplicação do herbicida Paraquat e aração convencional na mesofauna do solo na região de Manaus - AM. Acta Amazônica, v.12, n.1, p. 713, mar. 1982.

GUIA DE BOTUCATU. www.guiadebotucatu.com.br/hoje. (10 out. 2001)

KRANTZ, G.W. A manual of acarology. 2 ed. Corvallis: Oregon State University Book Stores, 1978. 509p.

LARINK, O. Springtail and Mites: important knots in the food web of soil. In: BENCKISER, G. (Ed.). Fauna in soil ecosystems: recycling processes, nutrient fluxes, and agricultural production. New York: Marcel Dekker, 1997. cap.7, p. 225264.

LIMA, W. P. Princípios de hidrologia florestal para o manejo de bacias hidrográficas. Piracicaba: ESALQ, 1986. 242p. 
LINDEN, D.R.; HNDIX, P.F.; COLEMAN, D.C.; VIET, P.C.J. van. Faunal indicators of soil quality. In: DORAN, J.W.; COLEMAN, D.C.; BEZDICEK, D.F.; STEWART, B.A. (Ed.). Defining soil quality for a sustainable environment. Wisconsin: SSSA, 1994. cap. 6, p.91-106.

LOPES ASSAD, M.L. Fauna do solo. In: VARGAS, M.A.T.; HUNGRIA, M. (Ed.) Biologia dos solos dos Cerrados. Planaltina: EMBRAPA, CPAC, 1997. cap. 7, p.363-444.

LUCHESI, L.A.C.; MORAES, A.; SANTOS, H.R.; SOUZA, M.L.P. Pastagens: um sistema de produção para a reabilitação de áreas degradadas. In: SIMPÓSIO NACIONAL DE RECUPERAÇÃO DE ÁREAS DEGRADADAS, Curitiba, 1992. Anais. Curitiba: UFPR; FUPEF, 1992. p. 83-92.

MACEDO, A.B. Panoramas da degradação da terra no Brasil. In: REBOUÇAS, A.C. (Org.). Panorama da degradação do ar, da água doce e da terra no Brasil. São Paulo: USP, IEA, 1997. p. 114-151.

MAKESCHIN, F. Earthworms (Lumbricidae: Oligochaeta): important promoters of soil development and soil fertility. In: BENCKISER, G. (Ed.). Fauna in soil ecosystems: recycling processes, nutrient fluxes, and agricultural production. New York: Marcel Dekker, 1997. cap.6, p. 173-223.

MELO, L.A.S. Impacto do manejo de agroecossistemas sobre a mesofauna do solo, em áreas de terra firme, na região de Manaus, AM. Manaus, 1984. 117p. Dissertação (Mestrado) - Instituto Nacional de Pesquisa da Amazônia, Fundação Universidade do Amazonas. 
MEZZOMO, J.A.; ZANUNCIO, J.C.; BARCELOS, J.A.C. Influência das faixas de vegetação nativa sobre coleoptera em Eucalyptus cloeziana. Revista Árvore, v.22, n.1, p. 77-87, jan./mar. 1998.

MIKLÓS, A.A.W. Papel de cupins e formigas na organização e na dinâmica da cobertura pedológica. In: FONTES, L.R.; BERTI FILHO, E. Cupins: o desafio do conhecimento. Piracicaba: FEALQ, 1998. p. 227-241.

MINEIRO, J.L.C. Ácaros edáficos do município de Piracicaba, Estado de São Paulo, com ênfase na família Ascidae (Gamasida). Jaboticabal, 2000. 98p. Dissertação (Mestrado) - Faculdade de Ciências Agrárias e Veterinárias, Universidade Estadual Paulista "Júlio de Mesquita Filho".

NOGUEIRA JUNIOR, L.R. Caracterização de solos degradados pela atividade agrícola e alterações biológicas após reflorestamentos com diferentes associações de espécies da Mata Atlântica. Piracicaba, 2000. 50p. Dissertação (Mestrado) Escola Superior de Agricultura "Luiz de Queiroz”, Universidade de São Paulo.

OLIVEIRA, A.R. Efeito do Baculovirus anticarsia sobre Oribatida edáficos (Arachnida: Acari) na cultura de soja. São Paulo, 1999. 69p. Dissertação (Mestrado) - Instituto de Biociências, Universidade de São Paulo.

PAIVA, C.L. Cupins e o patrimônio histórico edificado. In: FONTES, L. R.; BERTI FILHO, E. (Ed.). Cupins: o desafio do conhecimento. Piracicaba: FEALQ, 1998. p. $133-162$.

PASCHOAL, A.D.; MONTEIRO, A.R.; FERRAZ, L.C.C.B. Animais de interesse agrícola, veterinário e médico: apontamentos práticos de zoologia e parasitologia. Piracicaba: DECALQ, 1992. 224p. 
PASCHOAL, A.D.; MONTEIRO, A.R.; FERRAZ, L.C.C.B. et al. Fundamentos de zoologia agrícola e parasitologia: animais do meio rural e sua importância. Piracicaba: DECALQ, 1996. 98p.

PENNY, N.D.; ARIAS, J.R.; SCHUBART, H.O.R. Tendências populacionais da fauna de coleópteros do solo sob floresta de terra firme na Amazônia. Revista Acta Amazonica, v. 8, n.2, p.259-265, jun.1978.

POGGIANI, F.; OLIVEIRA, R.E. de; CUNHA, G.C. da. Práticas de ecologia florestal. Documentos Florestais, n.16, p.1-44, 1996.

PRIMAVESI, A. Manejo ecológico do solo: a agricultura em regiões tropicais. São Paulo: Nobel, 1990. 549p.

RAMOS, L.S. Impacto de práticas silviculturais sobre a diversidade de formigas (Hymenoptera: Formicidae) em eucaliptais. Lavras, 2001. 111p. Dissertação (Mestrado) - Universidade Federal de Lavras.

SAUTTER, K.D.; SANTOS, H.R. Recuperação de solos degradados pela mineração de xisto, tendo como bioindicadores insetos da Ordem Collembola. Revista do Setor de Ciências Agrárias, v.11, n.1/2, p.85-91, 1989/1991.

SAUTTER, K.D.; TREVISAN, E. Estudo da população de Oribatei (Acari: Cryptostigmata) e Collembola (Insecta) em três sítios distintos de acumulação orgânica sob povoamento de Pinus taeda L. Revista do Setor de Ciências Agrárias, v.13, n.1/2, p.161-166, 1994.

SOARES, M.I.J.; COSTA, E.C. Fauna do solo em áreas com Eucalyptus spp. e Pinus elliottii, Santa Maria, RS. Ciência Florestal, v.1, n.1, p.29-43, jun. 1991. 
SOS MATA ATLÂNTICA. www.sosmataatlantica.org.br. (21 nov. 2001)

TANCK, B.C.B.; SANTOS, H.R. \& DIONÍSIO, J.A Influência de diferentes sistemas de uso e manejo dos solos sobre a flutuação populacional do oligochaeta edáfico Amynthas spp. Revista Brasileira de Ciência do Solo, v.24, p. 409-415, 2000.

TEIXEIRA, L.B.; SCHUBART, H.O.R. Mesofauna do solo em áreas de floresta e pastagem na Amazônia Central. Boletim de Pesquisa EMBRAPA CPATU, n.95, p.1-16, out. 1988 .

TIBAU, A.O. Matéria orgânica e fertilidade do solo. 3.ed. São Paulo: Nobel, 1983. $221 \mathrm{p}$.

TRINCA, C.R. de. Materia Organica del Suelo. Revista Alcance, v.57, n. 4, p.73-96, jun. 1999.

TSAI, S.M.; BARAIBAR, A.V.L.; ROMANI, V.L.M. Efeito dos fatores do solo. In: CARDOSO, E.J.B.N.; TSAI, S.M.; NEVES, M.C.P. (Coord.) Microbiologia do solo. Campinas: SBCS, 1992. cap. 5, p. 59-72.

VELOSO, H.P.; GÓES FILHO, L. Fitogeografia brasileira: classificação fisionômicoecológica da vegetação neotropical. Salvador: RADAMBRASIL, 1982. 80p. (Série Vegetação, 1).

VELOSO, H.P.; RANGEL FILHO, A L.; LIMA, J.C.A Classificação da vegetação brasileira, adaptada a um sistema universal. Rio de Janeiro: IBGE, Departamento de Recursos Naturais e Estudos Ambientais, 1991. 124p. 
WILCKEN, C.F.; RAETANO, C.G. Controle de cupins em florestas. In: BERTI FILHO, E; FONTES, L. R. (Ed.) Alguns aspectos atuais da biologia e controle de cupins. Piracicaba: FEALQ, 1995. p. 141-154.

WOLTERS, V.; EKSCHMITT, K. Gastropods, Isopods, Diplopods, and Chilopods: neglicted groups of the decomposer food web. In: BENCKISER, G. (Ed.). Fauna in soil ecosystems: recycling processes, nutrient fluxes, and agricultural production. New York: Marcel Dekker, 1997. cap.8, p.265-306.

ZUCCHI, R.A.; SILVEIRA NETO, S; BATISTA, G.C. de. Reconhecimento de pragas. In: CURSO DE ENTOMOLOGIA APLICADA À AGRICULTURA, Piracicaba, 1992. Piracicaba: FEALQ, 1992. p.31-66. 